Supporting Information

For

\title{
A General and Practical Method of Alkynyl Indole and Benzofuran Synthesis via Tandem $\mathrm{Cu}$ and Pd-Catalyzed Cross Couplings
}

Masatoshi Nagamochi, Yuan-Qing Fang and Mark Lautens*

Davenport Research Laboratories, Department of Chemistry, University of Toronto 80 St. George Street, Toronto, Ontario, M5S 3H6, Canada

mlautens@chem.utoronto.ca 


\section{Table of Contents}

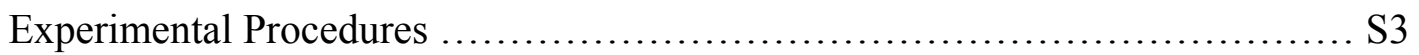

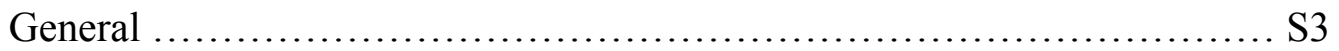

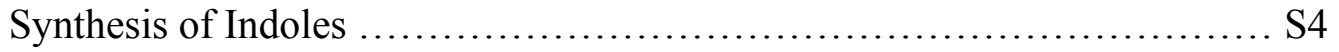

Synthesis of Benzofurans ......................................... S15

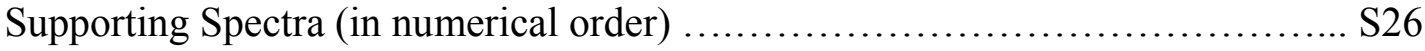


General All the reactions were carried out under argon or nitrogen. Glassware was oven dried. Solvents and solutions were added with a syringe. Analytical Thin Layer Chromatography was performed using Silicycle normal phase $0.25 \mathrm{~mm}$ aluminium-backed plates and visualization was accomplished with $250 \mathrm{~nm}$ UV light. Column chromatography was carried out as "flash chromatography" as reported by Still $^{1}$ using Silicycle ${ }^{\mathrm{TM}}$ Ultra-Pure 230-400 mesh silica gel.

All reagents, metal catalysts and ligands were obtained from commercial sources without further purification. Toluene was distilled under nitrogen from sodium/benzophenone immediately prior to use. Dichloromethane and dichloroethane were distilled under nitrogen from $\mathrm{CaH}_{2}$. $\mathrm{MeOH}$ and $\mathrm{DMF}$ were purchased from Aldrich and use without further distillation.

Melting points were taken on a Fisher-Johns melting point apparatus without correction. IR spectra were obtained using Nicolet DX FT IR spectrometer as a choroform solution with $\mathrm{NaCl}$ cellule. High-resolution mass spectra were obtained from a VG 70-250S (double focusing) mass spectrometer at $70 \mathrm{eV} .{ }^{1} \mathrm{H}$ and ${ }^{13} \mathrm{C}$ NMR spectra were obtained using Varian Mercury 400 or Mercury 300 spectrometers. Splitting patterns are indicated as s, singlet; $d$, doublet; $t$, triplet; q, quartet; quint, quintuplet; m, multiplet and br, broad peak. ${ }^{1} \mathrm{H}$ spectra were referenced to tetramethylsilane (TMS, $0 \mathrm{ppm}$ ) using $\mathrm{CDCl}_{3}$ or DMSO- $d_{6}$ as the solvent; ${ }^{13} \mathrm{C}$ spectra were referenced to solvent carbons $(77.0$ ppm for $\left.\mathrm{CDCl}_{3}\right)$.

${ }^{1}$ Still, W. C.; Kahn, M.; Mitra, A. J. Org. Chem. 1978, 43, 2923. 


\section{Synthesis of Indoles}

\section{Starting Materials (1) $)^{2}$}

\section{[2-(2,2-Dibromovinyl)phenyl]methylamine (1g)}<smiles>CNc1ccccc1C=C(Br)Br</smiles>

To a solution of [2-(2,2-dibromovinyl)phenyl]amine (1.15 g, $4.15 \mathrm{mmol})$, formaldehyde (37 wt. \% solutin in $\mathrm{H}_{2} \mathrm{O}, 400 \mathrm{mg}$ ), acetic acid $(0.5 \mathrm{~mL})$ in dichloroethane $(3 \mathrm{~mL})$ and $\mathrm{MeOH}(3 \mathrm{~mL})$ was added sodium triacetoxyborohydride $(1.10 \mathrm{~g}, 5.19 \mathrm{mmol})$ at $0{ }^{\circ} \mathrm{C}$, and the mixture was stirred for $24 \mathrm{~h}$ at $\mathrm{rt}$. The solvent was removed in vacuo and the resultant crude material was dissolved with EtOAc $(50 \mathrm{~mL})$ and sat. $\mathrm{NaHCO}_{3}(20 \mathrm{~mL})$. The mixture was extracted with EtOAc $(2 \times 50 \mathrm{~mL})$, and the combined organic layers were washed with brine, dried over $\mathrm{MgSO}_{4}$, filtered and then concentrated in vacuo. The resulting material was purified by flash chromatography eluting with $3 \% \rightarrow 5 \%$ EtOAc in hexane to give $1 \mathrm{~g}$ as a pale yellow oil (495 mg, 41\%). IR $\left(\mathrm{CHCl}_{3}\right) \vee 3418$, 2913, 2815, 1602, 1520, 1316, 1259, $1166 \mathrm{~cm}^{-1}$; ${ }^{1} \mathrm{H}-\mathrm{NMR}\left(\mathrm{CDCl}_{3}\right)$ \%: 7.31-7.23 (3H, m), $6.73(1 \mathrm{H}, \mathrm{dt}, J=7.6,0.9 \mathrm{~Hz}), 6.64(1 \mathrm{H}, \mathrm{d}, J=8.5 \mathrm{~Hz}), 3.65(1 \mathrm{H}, \mathrm{br} \mathrm{s}), 2.87(3 \mathrm{H}, \mathrm{s}) ;{ }^{13} \mathrm{C}$ NMR $\left(75 \mathrm{MHz} \mathrm{CDCl}_{3}\right) \delta 146.2,134.3,130.1,129.3,121.7,116.9,110.3,93.2,30.8$; HRMS (EI) $\mathrm{m} / \mathrm{z}$ calcd. for: $[\mathrm{M}]^{+}$288.9102, m/z found: 288.9103

\section{Indoles (2)}

\section{2-Phenylethynyl-1H-indole (2a)}
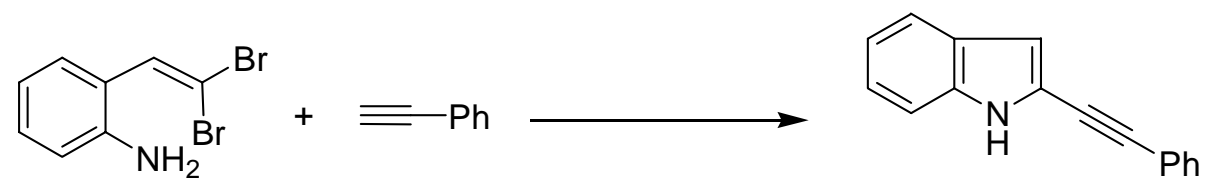

To a $10 \mathrm{~mL}$ round-bottomed flask was charged with $10 \% \mathrm{Pd}-\mathrm{C}$ (26.6 mg, $0.025 \mathrm{mmol})$ and $\mathrm{PPh}_{3}$ (14.4 mg, $0.055 \mathrm{mmol}$ ), and the flask was purged with argon for at least 10 min. To the second separate flask was charged with ortho-gem-dibromovinylaniline $(0.139 \mathrm{~g}, 0.5 \mathrm{mmol}), \mathrm{CuI}(4.8 \mathrm{mg}, 0.025 \mathrm{mmol})$, and the flask was purged with argon for

\footnotetext{
${ }^{2}$ More details about the starting material preparation not described here, see the Supporting Information: Fang, Y.-Q.; Lautens, M. Org. Lett. 2005, 7, 3549.
} 
$10 \mathrm{~min}$, followed by addition of toluene $(5 \mathrm{~mL})$, phenylacetylene $(82 \mu \mathrm{L}, 0.75 \mathrm{mmol})$, and $i \operatorname{Pr}_{2} \mathrm{NH}(174 \mu \mathrm{L}, 1.25 \mathrm{mmol})$. After the mixture in the second flask became homogenous, it was cannulated into the first flask, and the resulting mixture was heated at $100{ }^{\circ} \mathrm{C}$ for $1 \mathrm{~h}$. The mixture was diluted with $\mathrm{Et}_{2} \mathrm{O}(30 \mathrm{~mL})$, washed with $\mathrm{H}_{2} \mathrm{O}(20$ $\mathrm{mL})$, brine $(15 \mathrm{~mL})$, and dried over $\mathrm{MgSO}_{4}$. The crude material after removal of solvent was purified by flash chromatography using $5 \rightarrow 10 \%$ EtOAc in hexane to give 2a as a pale yellow solid $(0.088 \mathrm{~g}, 85 \%)$. mp: $161-162{ }^{\circ} \mathrm{C}$. IR (neat, $\left.\mathrm{cm}^{-1}\right): 3384,3052,2213$, 1596, 1482, 1442, 1398, 1353, 1308, 1235, 1104. ${ }^{1} \mathrm{H}$ NMR (300 MHz, $\left.\mathrm{CDCl}_{3}\right) \delta 8.22$ $(1 \mathrm{H}, \mathrm{br}), 7.60(1 \mathrm{H}, \mathrm{d}, J=7.9 \mathrm{~Hz}), 7.56-7.52(2 \mathrm{H}, \mathrm{m}), 7.37-7.32(4 \mathrm{H}, \mathrm{m}), 7.24(1 \mathrm{H}, \mathrm{ddd}$, $J=7.6,7.6,1.0 \mathrm{~Hz}), 7.13(1 \mathrm{H}, \mathrm{ddd}, J=7.5,7.5,0.9 \mathrm{~Hz}), 6.84(1 \mathrm{H}, \mathrm{d}, J=1.6 \mathrm{~Hz}) ;{ }^{13} \mathrm{C}$ $\operatorname{NMR}\left(75 \mathrm{MHz}, \mathrm{CDCl}_{3}\right) \delta 136.4,131.7,128.8,128.0,123.8,122.8,121.1,120.7,119.0$, $110.9,109.1,92.8,82.0$.

\section{2-Oct-1-ynyl-1H-indole (2b)}

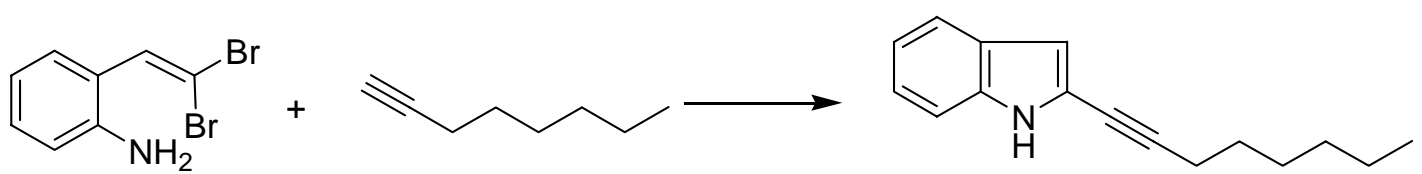

To a tube $(24 \times 150 \mathrm{~mm})$ of Carousel reaction station was charged with ortho-gem-dibromovinylaniline (139 mg, $0.50 \mathrm{mmol}), 10 \% \mathrm{Pd}-\mathrm{C}$ (10.6 mg, $0.010 \mathrm{mmol}$, $2 \mathrm{~mol} \%), \mathrm{P}(p-\mathrm{MeOPh})_{3}(14.1 \mathrm{mg}, 0.040 \mathrm{mmol}, 8 \mathrm{~mol} \%)$, and $\mathrm{CuI}(3.8 \mathrm{mg}, 0.020 \mathrm{mmol}$, $4 \mathrm{~mol} \%$ ), and the tube was evacuated and purged with argon three times followed by addition of toluene ( $3 \mathrm{~mL}$, degassed), $i \mathrm{Pr}_{2} \mathrm{NH}(175 \mu \mathrm{L}, 1.25 \mathrm{mmol})$, and 1-octyne (110 $\mu \mathrm{L}, 0.75 \mathrm{mmol})$. The reaction mixture was heated to $100^{\circ} \mathrm{C}$ for $1.5 \mathrm{~h} . \mathrm{H}_{2} \mathrm{O}(10 \mathrm{~mL})$ was added, and the mixture was extracted with EtOAc $(2 \times 15 \mathrm{~mL})$, and dried over $\mathrm{MgSO}_{4}$. The crude material after removal of solvent was purified by flash chromatography using $3 \%$ EtOAc in hexane to afford $\mathbf{2 b}$ as a pale yellow oil $(93.5 \mathrm{mg}, 83 \%)$. IR (neat, $\mathrm{cm}^{-1}$ ) 3410, 2931, 2858, 2231, 1453, 1349, 1296, 1145. ${ }^{1} \mathrm{H}$ NMR (300 MHz, $\left.\mathrm{CDCl}_{3}\right) \delta 8.07$ $(1 \mathrm{H}, \mathrm{br}), 7.55(1 \mathrm{H}, \mathrm{d}, J=7.9 \mathrm{~Hz}), 7.26(1 \mathrm{H}, \mathrm{d}, J=8.0 \mathrm{~Hz}), 7.19(1 \mathrm{H}, J=7.6,7.6,0.9$ $\mathrm{Hz}), 7.09(1 \mathrm{H}, \mathrm{ddd}, J=7.4,7.4,1.2 \mathrm{~Hz}), 6.65(1 \mathrm{H}, \mathrm{m}), 2.44(2 \mathrm{H}, \mathrm{t}, J=7.1 \mathrm{~Hz})$, $1.66-1.56(2 \mathrm{H}, \mathrm{m}), 1.49-1.41(2 \mathrm{H}, \mathrm{m}), 1.34-1.28(4 \mathrm{H}, \mathrm{m}), 0.91(3 \mathrm{H}, \mathrm{t}, J=6.8 \mathrm{~Hz})) ;{ }^{13} \mathrm{C}$ NMR (100 MHz, $\left.\mathrm{CDCl}_{3}\right) \delta 135.9,128.0,123.1,120.7,120.4,119.8,110.7,107.6,94.1$, 73.2, 31.6, 28.8, 28.7, 22.7, 19.8, 14.3. HRMS (ESI) calc'd for $\mathrm{C}_{16} \mathrm{H}_{19} \mathrm{~N}\left([\mathrm{M}]^{+}\right)$: 225.1518. Found: 225.1517. 


\section{5-(1H-Indol-2-yl)-pent-4-yn-1-ol (2c)}

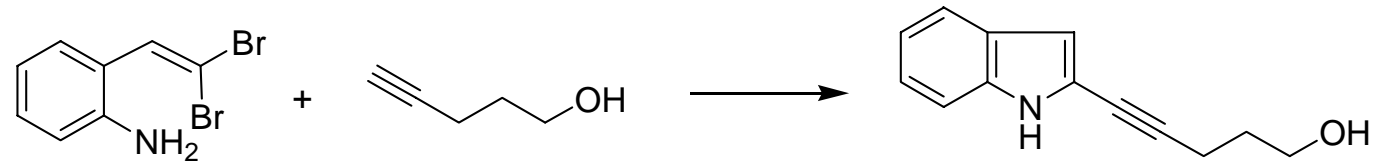

To a $10 \mathrm{~mL}$ round-bottomed flask was charged with $10 \% \mathrm{Pd}-\mathrm{C}(26.6 \mathrm{mg}, 0.025 \mathrm{mmol})$ and $\mathrm{PPh}_{3}(14.4 \mathrm{mg}, 0.055 \mathrm{mmol})$, and the flask was purged with argon for at least 10 min. To the second separate flask was charged with ortho-gem-dibromovinylaniline $(0.139 \mathrm{~g}, 0.5 \mathrm{mmol}), \mathrm{CuI}(4.8 \mathrm{mg}, 0.025 \mathrm{mmol})$, and the flask was purged with argon for $10 \mathrm{~min}$, followed by addition of toluene $(5 \mathrm{~mL})$, pent-4-yn-1-ol $(69 \mu \mathrm{L}, 0.75 \mathrm{mmol})$, and $i \operatorname{Pr}_{2} \mathrm{NH}(174 \mu \mathrm{L}, 1.25 \mathrm{mmol})$. After the mixture in the second flask became homogenous, it was cannulated into the first flask, and the resulting mixture was heated at $100{ }^{\circ} \mathrm{C}$ for $1 \mathrm{~h}$. The mixture was diluted with $\mathrm{Et}_{2} \mathrm{O}(30 \mathrm{~mL})$, washed with $\mathrm{H}_{2} \mathrm{O}(20 \mathrm{~mL})$, brine $(15$ $\mathrm{mL}$ ), and dried over $\mathrm{MgSO}_{4}$. The crude material was purified by flash chromatography using $3.5 \rightarrow 5 \%$ EtOAc in hexane to afford $2 \mathrm{c}$ as a pale yellow oil $(0.065 \mathrm{~g}, 65 \%)$. IR (neat, $\mathrm{cm}^{-1}$ ): 3541, 3396, 2948, 2233, 1451, 1350, 1296, 1046. ${ }^{1} \mathrm{H}$ NMR (300 MHz, $\left.\mathrm{CDCl}_{3}\right) \delta 8.35(1 \mathrm{H}, \mathrm{br}), 7.55(1 \mathrm{H}, \mathrm{d}, J=7.9 \mathrm{~Hz}), 7.25(1 \mathrm{H}, \mathrm{d}, J=8.1 \mathrm{~Hz}), 7.18(1 \mathrm{H}, J=$ 7.6, 7.6, 1.1 Hz), 7.09 (1H, ddd, $J=7.5,7.5,0.9 \mathrm{~Hz}), 6.65(1 \mathrm{H}, \mathrm{d}, J=1.5 \mathrm{~Hz}), 3.80(2 \mathrm{H}$, $\mathrm{t}, J=5.3 \mathrm{~Hz}), 2.56(2 \mathrm{H}, \mathrm{t}, J=7.0 \mathrm{~Hz}), 1.97(1 \mathrm{H}, \mathrm{br}), 1.85(2 \mathrm{H}$, quintet, $J=6.5 \mathrm{~Hz}) ;{ }^{13} \mathrm{C}$ $\operatorname{NMR}\left(75 \mathrm{MHz}, \mathrm{CDCl}_{3}\right) \delta 136.0,127.9,123.2,120.8,120.4,119.4,110.9,107.7,92.9$, 73.8, 61.8, 31.3, 16.3. HRMS (EI) calc'd for $\mathrm{C}_{13} \mathrm{H}_{13} \mathrm{NO}\left([\mathrm{M}]^{+}\right)$: 199.0997. Found: 199.0995.

\section{2-[5-(Tetrahydropyran-2-yloxy)-pent-1-ynyl]-1H-indole (2d)}

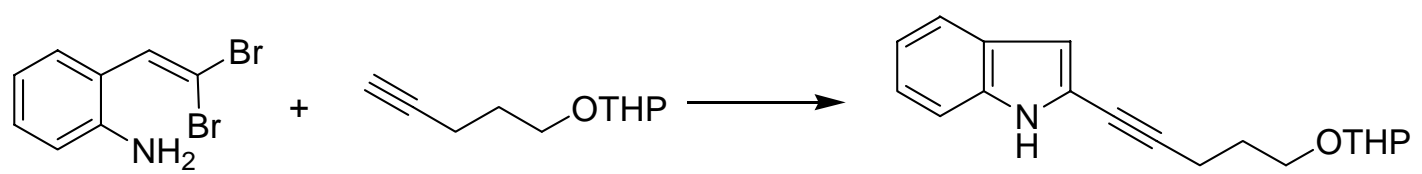

To a $10 \mathrm{~mL}$ round-bottomed flask was charged with $10 \% \mathrm{Pd}-\mathrm{C}$ (26.6 mg, $0.025 \mathrm{mmol})$ and $\mathrm{PPh}_{3}(14.4 \mathrm{mg}, 0.055 \mathrm{mmol})$, and the flask was purged with argon for at least 10 min. To the second separate flask was charged with ortho-gem-dibromovinylaniline $(0.139 \mathrm{~g}, 0.5 \mathrm{mmol}), \mathrm{CuI}(4.8 \mathrm{mg}, 0.025 \mathrm{mmol})$, and the flask was purged with argon for $10 \mathrm{~min}$, followed by addition of toluene $(5 \mathrm{~mL})$, 2-pent-4-ynyloxytetrahydropyran $(0.115 \mathrm{~g}, 0.676 \mathrm{mmol})$, and $i \operatorname{Pr}_{2} \mathrm{NH}(174 \mu \mathrm{L}, 1.25 \mathrm{mmol})$. After the mixture in the second flask became homogenous, it was cannulated into the first flask, and the resulting mixture was heated at $100{ }^{\circ} \mathrm{C}$ for $1 \mathrm{~h}$. The crude material was purified by flash chromatography using $15 \rightarrow 20 \%$ EtOAc in hexanes to afford $2 \mathbf{d}$ as a slightly yellow oil (0.105 g, 71\%). IR (neat, $\left.\mathrm{cm}^{-1}\right): 3406,3283,2944,2870,2244,1452,1350,1296,1137$, 1119, 1033. ${ }^{1} \mathrm{H}$ NMR (300 MHz, $\left.\mathrm{CDCl}_{3}\right) \delta 8.27(1 \mathrm{H}, \mathrm{br}), 7.55(1 \mathrm{H}, \mathrm{d}, J=7.8 \mathrm{~Hz}), 7.28$ 
$(1 \mathrm{H}, \mathrm{d}, J=8.1 \mathrm{~Hz}), 7.19(1 \mathrm{H}, J=7.5,7.5,0.9 \mathrm{~Hz}), 7.09(1 \mathrm{H}, \mathrm{t}, J=7.6 \mathrm{~Hz}), 6.64(1 \mathrm{H}, \mathrm{d}$, $J=1.8 \mathrm{~Hz}), 4.65(1 \mathrm{H}, \mathrm{t}, J=3.4 \mathrm{~Hz}), 3.95-3.88(2 \mathrm{H}, \mathrm{m}), 3.59-3.50(2 \mathrm{H}, \mathrm{m}), 2.58(2 \mathrm{H}, \mathrm{t}$, $J=7.1 \mathrm{~Hz}), 1.96-1.70(4 \mathrm{H}, \mathrm{m}), 1.63-1.54(4 \mathrm{H}, \mathrm{m}) ;{ }^{13} \mathrm{C} \mathrm{NMR}\left(75 \mathrm{MHz}, \mathrm{CDCl}_{3}\right) \delta 135.9$, $127.9,123.1,120.8,120.4,119.6,110.8,107.6$, 99.1, 93.2, 73.6, 66.1, 62.5, 30.9, 28.9, 25.7, 19.7, 16.7. HRMS (EI) calc'd for $\mathrm{C}_{18} \mathrm{H}_{21} \mathrm{NO}_{2}\left([\mathrm{M}]^{+}\right)$: 283.1572. Found: 283.1572.

\section{3-(1H-Indol-2-yl)prop-2-yn-1-ol (2e)}

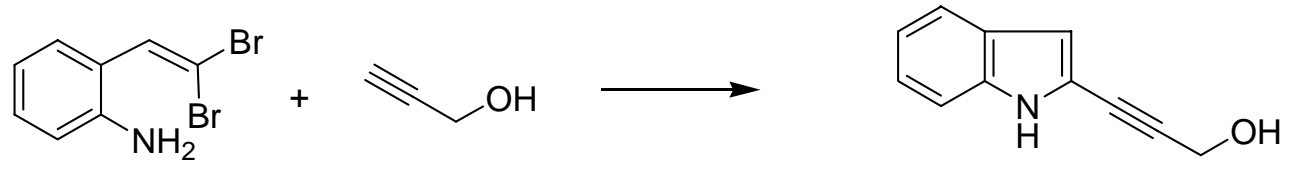

A carousel reaction tube $(24 \times 150 \mathrm{~mm})$ was charged with 2-(2,2-Dibromovinyl)aniline (120 mg, $0.43 \mathrm{mmol}), 10 \% \mathrm{Pd}-\mathrm{C}$ (9.2 mg, $0.0087 \mathrm{mmol}, 2 \mathrm{~mol} \%), \mathrm{P}(p-\mathrm{MeOPh})_{3}(12.0$ $\mathrm{mg}, 0.034 \mathrm{mmol}, 8 \mathrm{~mol} \%$ ), and $\mathrm{CuI}$ (3.9 mg, $0.020 \mathrm{mmol}, 4 \mathrm{~mol} \%$ ), and was evacuated and purged with argon three times. To this mixture were added toluene ( $3 \mathrm{~mL}$, degassed), $i \operatorname{Pr}_{2} \mathrm{NH}(157 \mu \mathrm{L}, 1.12 \mathrm{mmol})$ and propargyl alcohol $(0.30 \mathrm{ml}, 5.2 \mathrm{mmol})$, and then heated to $100{ }^{\circ} \mathrm{C}$ with stirring for $12 \mathrm{~h}$. The reaction mixture was then cooled to $\mathrm{rt}$ and $\mathrm{H}_{2} \mathrm{O}(10 \mathrm{~mL})$ added. The mixture was extracted with EtOAc $(2 \times 15 \mathrm{~mL})$, and combined extracts were washed with sat. $\mathrm{NH}_{4} \mathrm{Cl}$ and brine, then dried and solvent was removed in vacuo. The resulting crude material was purified by flash chromatography eluting with $50 \rightarrow 60 \%$ EtOAc in hexane to afford $2 \mathbf{e}$ as a pale brown solid (29.6 $\mathrm{mg}, 40 \%)$. mp: 49-51 ${ }^{\circ} \mathrm{C}$; IR $\left(\mathrm{CHCl}_{3}\right) \vee 3398,2923,2228,1450,1403,1350,1299,1229,1038,1012$ $\mathrm{cm}^{-1} ;{ }^{1} \mathrm{H}-\mathrm{NMR}\left(\mathrm{CDCl}_{3}\right) \delta: 8.19(1 \mathrm{H}, \mathrm{s}), 7.58(1 \mathrm{H}, \mathrm{d}, J=7.6 \mathrm{~Hz}), 7.19-7.19(2 \mathrm{H}, \mathrm{m})$, $7.12(1 \mathrm{H}, \mathrm{t}, J=7.3 \mathrm{~Hz}), 6.76(1 \mathrm{H}, \mathrm{br} \mathrm{s}), 4.54(2 \mathrm{H}, \mathrm{s}), 1.82(1 \mathrm{H}$, br s$) ;{ }^{13} \mathrm{C} \mathrm{NMR}(75$ $\left.\mathrm{MHz}, \mathrm{CDCl}_{3}\right) \delta 127.7,123.9,121.1,120.7,111.0,109.3,90.8,51.8 ; \mathrm{HRMS}(\mathrm{EI}) \mathrm{m} / \mathrm{z}$ calcd. for: $[\mathrm{M}]^{+} 171.0684, \mathrm{~m} / \mathrm{z}$ found: 171.0682 .

\section{2-Trimethylsilanylethynyl-1H-indole (2f)}

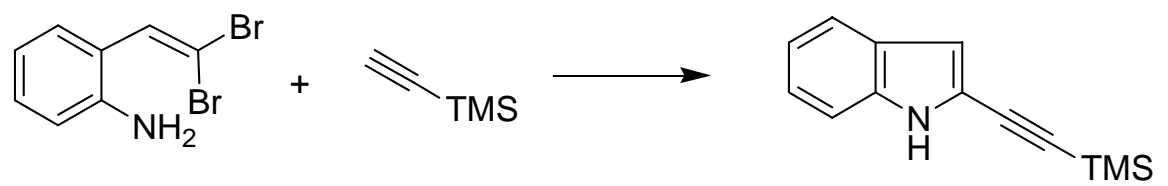

A carousel reaction tube $(24 \times 150 \mathrm{~mm})$ was charged with 2-(2,2-dibromovinyl)aniline (139 mg, $0.50 \mathrm{mmol}), 10 \%$ Pd-C (10.6 mg, $0.01 \mathrm{mmol}, 2 \mathrm{~mol} \%), \mathrm{P}(p-\mathrm{OMeP})_{3}(14.2 \mathrm{mg}$, $0.040 \mathrm{mmol}, 8 \mathrm{~mol} \%$ ), and $\mathrm{CuI}(3.8 \mathrm{mg}, 0.020 \mathrm{mmol}, 4 \mathrm{~mol} \%)$, and was evacuated and purged with argon three times. To this mixture were added toluene ( $3 \mathrm{~mL}$, degassed), $i \operatorname{Pr}_{2} \mathrm{NH}(175 \mu \mathrm{L}, 1.25 \mathrm{mmol})$ and trimethylsilylacetylene $(0.71 \mathrm{ml}, 5.0 \mathrm{mmol})$, and then heated to $100{ }^{\circ} \mathrm{C}$ with stirring for $12 \mathrm{~h}$. The reaction mixture was then cooled to $\mathrm{rt}$ and $\mathrm{H}_{2} \mathrm{O}(10 \mathrm{~mL})$ added. The mixture was extracted with EtOAc $(2 \times 15 \mathrm{~mL})$, and combined extracts were washed with sat. $\mathrm{NH}_{4} \mathrm{Cl}$ and brine, then dried and solvent was removed in 
vacuo. The resulting crude material was purified by flash chromatography eluting with $10 \%$ EtOAc in hexane to afford $\mathbf{2 f}$ as a pale brown solid $(61.0 \mathrm{mg}, 57 \%) . \mathrm{mp}$ : $91-92{ }^{\circ} \mathrm{C}$; IR $\left(\mathrm{CHCl}_{3}\right) \vee 3402,2961,2157,1398,1343,1249 \mathrm{~cm}^{-1} ;{ }^{1} \mathrm{H}-\mathrm{NMR}\left(\mathrm{CDCl}_{3}\right) \delta: 8.16(1 \mathrm{H}$, br s), $7.57(1 \mathrm{H}, \mathrm{d}, J=7.9 \mathrm{~Hz}), 7.29(1 \mathrm{H}, \mathrm{dd}, J=7.9,1.2 \mathrm{~Hz}), 7.22(1 \mathrm{H}, \mathrm{td}, J=7.9,1.2$ $\mathrm{Hz}), 7.11(2 \mathrm{H}, \mathrm{td}, J=7.9,1.2 \mathrm{~Hz}), 6.77(1 \mathrm{H}, \mathrm{d}, J=1.2 \mathrm{~Hz}), 0.27(9 \mathrm{H}, \mathrm{s}) ;{ }^{13} \mathrm{C} \mathrm{NMR}(75$ $\left.\mathrm{MHz}, \mathrm{CDCl}_{3}\right) \delta 135.8,127.4,123.6,120.9,120.4,118.5,110.6,109.2,98.3,96.8,-0.20$; HRMS (EI) m/z calcd. for: [M] $]^{+} 213.0974, \mathrm{~m} / \mathrm{z}$ found: 213.0974 .

\section{6-(1H-Indol-2-yl)hex-5-ynenitrile (2g)}<smiles>C#CCCCC#N</smiles>

A carousel reaction tube $(24 \times 150 \mathrm{~mm})$ was charged with 2-(2,2-dibromovinyl)aniline (139 mg, $0.50 \mathrm{mmol}), 10 \% \mathrm{Pd}-\mathrm{C}$ (10.6 mg, $0.0087 \mathrm{mmol}, 2 \mathrm{~mol} \%), \mathrm{P}(p-\mathrm{MeOPh})_{3}(14.1$ $\mathrm{mg}, 0.040 \mathrm{mmol}, 8 \mathrm{~mol} \%$ ), and $\mathrm{CuI}$ (3.9 mg, $0.020 \mathrm{mmol}, 4 \mathrm{~mol} \%$ ), and was evacuated and purged with argon three times. To this mixture were added toluene ( $3 \mathrm{~mL}$, degassed), $i \operatorname{Pr}_{2} \mathrm{NH}(180 \mu \mathrm{L}, 1.28 \mathrm{mmol})$ and 5-hexynenitrile $(80 \mu \mathrm{L}, 0.75 \mathrm{mmol})$, and then heated to $100{ }^{\circ} \mathrm{C}$ with stirring for $24 \mathrm{~h}$. The reaction mixture was then cooled to $\mathrm{rt}$ and $\mathrm{H}_{2} \mathrm{O}(10$ $\mathrm{mL})$ added. The mixture was extracted with EtOAc $(2 \times 15 \mathrm{~mL})$, and combined extracts were washed with sat. $\mathrm{NH}_{4} \mathrm{Cl}$ and brine, then dried and solvent was removed in vacuo. The resulting crude material was purified by flash chromatography eluting with $25 \%$ EtOAc in hexane to afford $\mathbf{2 g}$ as a pale brown oil $(52.3 \mathrm{mg}, 50 \%)$. IR $\left(\mathrm{CHCl}_{3}\right) \vee 3390$, 2358, 1995, 1350, $1295 \mathrm{~cm}^{-1} ;{ }^{1} \mathrm{H}-\mathrm{NMR}\left(\mathrm{CDCl}_{3}\right) \delta: 8.23(1 \mathrm{H}, \mathrm{s}), 7.56(1 \mathrm{H}, \mathrm{d}, J=7.9 \mathrm{~Hz})$, 7.33-7.07 (3H, m), $6.68(1 \mathrm{H}$, br s), $2.65(2 \mathrm{H}, \mathrm{t}, J=6.7 \mathrm{~Hz}), 2.56(2 \mathrm{H}, \mathrm{t}, J=7.0 \mathrm{~Hz})$, 2.03-1.92 (2H, m); ${ }^{13} \mathrm{C}$ NMR (75 MHz, $\left.\mathrm{CDCl}_{3}\right) \delta$ 136.0, 127.8, 123.5, 120.9, 120.6, 119.4, 118.8, 110.9, 108.2, 90.6, 75.2, 24.5, 19.0, 16.5; HRMS (EI) m/z calcd. for: $[\mathrm{M}]^{+}$ 208.1000, $\mathrm{m} / \mathrm{z}$ found: 208.0996 .

\section{2-(6-Chlorohex-1-ynyl)-1H-indole (2h)}

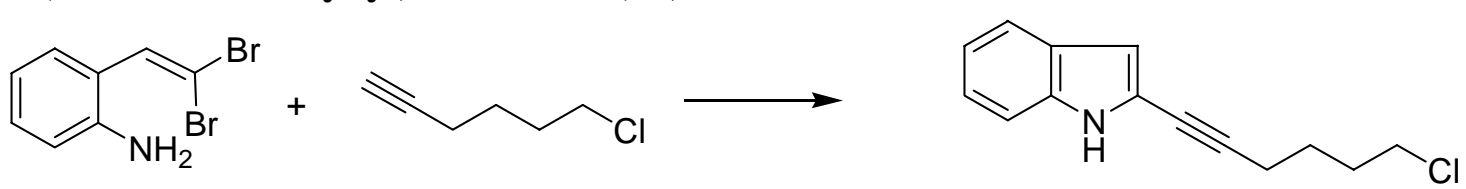

A carousel reaction tube $(24 \times 150 \mathrm{~mm})$ was charged with 2-(2,2-dibromovinyl)aniline (139 mg, $0.50 \mathrm{mmol}), 10 \% \mathrm{Pd}-\mathrm{C}$ (10.6 mg, $0.0087 \mathrm{mmol}, 2 \mathrm{~mol} \%), \mathrm{P}(p-\mathrm{MeOPh})_{3}(12.0$ $\mathrm{mg}, 0.034 \mathrm{mmol}, 8 \mathrm{~mol} \%$ ), and $\mathrm{CuI}$ (3.9 mg, $0.020 \mathrm{mmol}, 4 \mathrm{~mol} \%$ ), and was evacuated and purged with argon three times. To this mixture were added toluene ( $3 \mathrm{~mL}$, degassed), 
$i \operatorname{Pr}_{2} \mathrm{NH}(175 \mu \mathrm{L}, 1.25 \mathrm{mmol})$ and 6-chloro-1-hexyne $(80 \mu \mathrm{L}, 0.75 \mathrm{mmol})$, and then heated to $100{ }^{\circ} \mathrm{C}$ with stirring for $48 \mathrm{~h}$. The reaction mixture was then cooled to $\mathrm{rt}$ and $\mathrm{H}_{2} \mathrm{O}(10 \mathrm{~mL})$ added. The mixture was extracted with EtOAc $(2 \times 15 \mathrm{~mL})$, and combined extracts were washed with sat. $\mathrm{NH}_{4} \mathrm{Cl}$ and brine, then dried and solvent was removed in vacuo. The resulting crude material was purified by flash chromatography eluting with $15 \%$ EtOAc in hexane to afford $\mathbf{2 h}$ as a pale yellow oil $(81.3 \mathrm{mg}, 70 \%)$. IR $\left(\mathrm{CHCl}_{3}\right) \mathrm{v}$ 3405, 2950, 1615, 1538, 1451, 1349, $1295 \mathrm{~cm}^{-1}$; ${ }^{1} \mathrm{H}-\mathrm{NMR}\left(\mathrm{CDCl}_{3}\right) \delta: 8.08(1 \mathrm{H}, \mathrm{s}), 7.55$ $(1 \mathrm{H}, \mathrm{d}, J=7.9 \mathrm{~Hz}), 7.33-7.05(3 \mathrm{H}, \mathrm{m}), 6.66(1 \mathrm{H}, \mathrm{d}, J=1.5 \mathrm{~Hz}), 3.60(2 \mathrm{H}, \mathrm{t}, J=6.4 \mathrm{~Hz})$, $2.50(2 \mathrm{H}, \mathrm{t}, J=6.9 \mathrm{~Hz}), 2.02-1.71(4 \mathrm{H}, \mathrm{m}) ;{ }^{13} \mathrm{C} \mathrm{NMR}\left(75 \mathrm{MHz}, \mathrm{CDCl}_{3}\right) \delta 135.9,127.9$, 123.3, 120.8, 120.5, 119.4, 110.8, 107.9, 93.0, 73.8, 44.7, 31.9, 25.9, 19.1; HRMS (ESI) $\mathrm{m} / \mathrm{z}$ calcd. for: $[\mathrm{M}+\mathrm{H}]^{+} 232.0890, \mathrm{~m} / \mathrm{z}$ found: 232.0887 .

\section{2-Pyridin-3-ylethynyl-1H-indole (2i)}

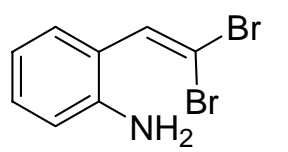<smiles>C#Cc1cccnc1</smiles>
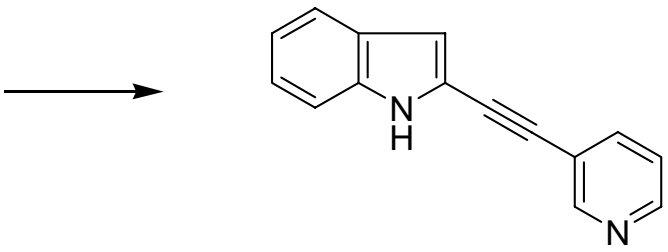

A carousel reaction tube $(24 \times 150 \mathrm{~mm})$ was charged with 2-(2,2-dibromovinyl)aniline (139 mg, $0.50 \mathrm{mmol}), 10 \% \mathrm{Pd}-\mathrm{C}$ (10.6 mg, $0.010 \mathrm{mmol}, 2 \mathrm{~mol} \%), \mathrm{P}(p-\mathrm{MeOPh})_{3}(14.1$ $\mathrm{mg}, 0.040 \mathrm{mmol}, 8 \mathrm{~mol} \%$ ), and $\mathrm{CuI}(3.8 \mathrm{mg}, 0.020 \mathrm{mmol}, 4 \mathrm{~mol} \%)$, and was evacuated and purged with argon three times. To this mixture were added toluene ( $3 \mathrm{~mL}$, degassed), $i \operatorname{Pr}_{2} \mathrm{NH}(175 \mu \mathrm{L}, 1.25 \mathrm{mmol})$ and 3-ethynylpyridine $(80.0 \mathrm{mg}, 0.77 \mathrm{mmol})$, and then heated to $100{ }^{\circ} \mathrm{C}$ with stirring for $12 \mathrm{~h}$. The reaction mixture was then cooled to $\mathrm{rt}$ and $\mathrm{H}_{2} \mathrm{O}(10 \mathrm{~mL})$ added. The mixture was extracted with EtOAc $(2 \times 15 \mathrm{~mL})$, and combined extracts were washed with sat. $\mathrm{NH}_{4} \mathrm{Cl}$ and brine, then dried and solvent was removed in vacuo. The resulting crude material was purified by flash chromatography eluting with $40 \%$ EtOAc in hexane to afford $2 \mathbf{i}$ as a white solid (88.0 mg, $81 \%$ ). mp: $209-21{ }^{\circ} \mathrm{C}$; IR $\left(\mathrm{CHCl}_{3}\right)$ v 3403, 2157, 1652, 1558, 1539, 1506, 1457, $1249 \mathrm{~cm}^{-1} ;{ }^{1} \mathrm{H}-\mathrm{NMR}\left(\mathrm{CDCl}_{3}\right) \delta$ : $8.83(1 \mathrm{H}, \mathrm{s}), 8.60(1 \mathrm{H}, \mathrm{s}), 7.83(1 \mathrm{H}, \mathrm{dt}, J=8.1,1.8 \mathrm{~Hz}), 7.63(1 \mathrm{H}, \mathrm{d}, J=8.1 \mathrm{~Hz})$, 7.41-7.22 (4H, m), 7.19-7.10 (1H, m), $6.89(1 \mathrm{H}, \mathrm{dd}, J=2.1,0.9 \mathrm{~Hz}) ;{ }^{13} \mathrm{C}$ NMR $(75$ MHz, DMSO- $\left.d_{6}\right) \delta 152.0,149.7,139.0,137.2,127.7,124.4,123.9,121.2,120.6,119.8$, 118.1, 112.0, 109.0, 89.2, 86.5; HRMS (EI) $\mathrm{m} / \mathrm{z}$ calcd. for: $[\mathrm{M}]^{+} 218.0844, \mathrm{~m} / \mathrm{z}$ found: 218.0846 . 
2-Oct-1-ynyl-1H-benzo[g]indole (2j)<smiles>C#CCCCCCCCCCCCCCC#Cc1cc2ccc3ccccc3c2[nH]1</smiles>

A carousel reaction tube $(24 \times 150 \mathrm{~mm})$ was charged with 2-(2,2-dibromovinyl)naphthalen-1-ylamine (110 mg, $0.34 \mathrm{mmol}), 10 \% \mathrm{Pd}-\mathrm{C}(7.1 \mathrm{mg}$, $0.0066 \mathrm{mmol}, 2 \mathrm{~mol} \%), \mathrm{P}(p-\mathrm{MeOPh})_{3}(4.6 \mathrm{mg}, 0.013 \mathrm{mmol}, 4 \mathrm{~mol} \%)$, and $\mathrm{CuI}(2.8 \mathrm{mg}$, $0.0066 \mathrm{mmol}, 2 \mathrm{~mol} \%$ ), and was evacuated and purged with argon three times. To this mixture were added toluene $\left(3 \mathrm{~mL}\right.$, degassed), $i \operatorname{Pr}_{2} \mathrm{NH}(120 \mu \mathrm{L}, 0.84 \mathrm{mmol})$ and 1-octynye ( $80 \mu \mathrm{L}, 0.54 \mathrm{mmol}$ ), and then heated to $100{ }^{\circ} \mathrm{C}$ with stirring for $12 \mathrm{~h}$. The reaction mixture was then cooled to $\mathrm{rt}$ and $\mathrm{H}_{2} \mathrm{O}(10 \mathrm{~mL})$ added. The mixture was extracted with EtOAc $(2 \times 15 \mathrm{~mL})$, and combined extracts were washed with sat. $\mathrm{NH}_{4} \mathrm{Cl}$ and brine, then dried and solvent was removed in vacuo. The resulting crude material was purified by flash chromatography eluting with $15 \%$ EtOAc in hexane to afford $\mathbf{2} \mathbf{j}$ as a pale brown solid (51.0 mg, 55\%). mp: 90-91 ${ }^{\circ} \mathrm{C}$; IR $\left(\mathrm{CHCl}_{3}\right) \vee 3414,2930,1519,1393$ $\mathrm{cm}^{-1} ;{ }^{1} \mathrm{H}-\mathrm{NMR}\left(\mathrm{CDCl}_{3}\right) \delta: 8.83(1 \mathrm{H}, \mathrm{s}), 7.85-7.85(2 \mathrm{H}, \mathrm{m}), 7.61(1 \mathrm{H}, \mathrm{d}, J=8.8 \mathrm{~Hz})$, 7.54-7.37 (3H, m), $6.78(1 \mathrm{H}, \mathrm{d}, J=2.1 \mathrm{~Hz}), 2.48(2 \mathrm{H}, \mathrm{t}, J=7.0 \mathrm{~Hz}), 1.72-1.23(8 \mathrm{H}, \mathrm{m})$, $0.92(3 \mathrm{H}, \mathrm{t}, J=6.7 \mathrm{~Hz}) ;{ }^{13} \mathrm{C} \mathrm{NMR}\left(75 \mathrm{MHz}, \mathrm{CDCl}_{3}\right) \delta 131.0,130.6,129.1,125.8,124.4$, 124.0, 121.5, 121.4, 120.6, 119.7, 118.0, 109.2, 93.9, 73.2, 31.6, 28.9, 28.8, 22.8, 19.8, 14.3; HRMS (EI) m/z calcd. for: [M] $]^{+} 275.1674, \mathrm{~m} / \mathrm{z}$ found: 275.1679.

\section{4-Benzyloxy-5-methoxy-2-oct-1-ynyl-1H-indole (2k)}<smiles>CCCCCCC#Cc1cc2c(OCC)c(OC)ccc2[nH]1</smiles>

A carousel reaction tube $(24 \times 150 \mathrm{~mm})$ was charged with 3-benzyloxy-2-(2,2-dibromovinyl)-4-methoxyphenylamine (136 mg, $0.33 \mathrm{mmol}$ ), 10\% Pd-C (7.0 mg, $0.0066 \mathrm{mmol}, 2 \mathrm{~mol} \%), \mathrm{P}(p-\mathrm{MeOPh})_{3}$ (4.6 mg, $0.013 \mathrm{mmol}, 4 \mathrm{~mol} \%$ ), and $\mathrm{CuI}(1.3 \mathrm{mg}, 0.0063 \mathrm{mmol}, 2 \mathrm{~mol} \%)$, and was evacuated and purged with argon three times. To this mixture were added toluene ( $3 \mathrm{~mL}$, degassed), $\operatorname{Pr}_{2} \mathrm{NH}(140 \mu \mathrm{L}, 1.0$ mmol) and 1-octynye $(118 \mu \mathrm{L}, 0.85 \mathrm{mmol})$, and then heated to $100{ }^{\circ} \mathrm{C}$ with stirring for $12 \mathrm{~h}$. The reaction mixture was then cooled to $\mathrm{rt}$ and $\mathrm{H}_{2} \mathrm{O}(10 \mathrm{~mL})$ added. The mixture was extracted with EtOAc $(2 \times 15 \mathrm{~mL})$, and combined extracts were washed with sat. $\mathrm{NH}_{4} \mathrm{Cl}$ and brine, then dried and solvent was removed in vacuo. The resulting crude 
material was purified by flash chromatography eluting with 5\% EtOAc in hexane to afford 2k as a colorless oil (96.0 mg, 81\%). IR $\left(\mathrm{CHCl}_{3}\right) \vee 3334,3031,2930,2857,1583$, 1504, 1463, 1454, 1428, 1331, 1282, 1245, 1174, $1093 \mathrm{~cm}^{-1} ;{ }^{1} \mathrm{H}-\mathrm{NMR}\left(\mathrm{CDCl}_{3}\right) \delta: 7.98$ $(1 \mathrm{H}, \mathrm{s}), 7.55-7.48(2 \mathrm{H}, \mathrm{m}), 7.41-7.27(3 \mathrm{H}, \mathrm{m}), 6.94(2 \mathrm{H}, \mathrm{t}, J=9.4 \mathrm{~Hz}), 6.69(1 \mathrm{H}, \mathrm{d}, J=$ $2.1 \mathrm{~Hz}), 5.21(2 \mathrm{H}, \mathrm{s}), 3.87(3 \mathrm{H}, \mathrm{s}), 2.43(2 \mathrm{H}, \mathrm{t}, J=7.0 \mathrm{~Hz}), 1.67-1.24(8 \mathrm{H}, \mathrm{m}), 0.91(3 \mathrm{H}$, $\mathrm{t}, J=6.9 \mathrm{~Hz}) ;{ }^{13} \mathrm{C}$ NMR $\left(75 \mathrm{MHz}, \mathrm{CDCl}_{3}\right) \delta 145.5,140.8,138.4,133.0,128.5,128.2$, 127.9, 123.4, 120.1, 113.3, 105.9, 105.1, 94.1, 75.2, 73.0, 58.6, 31.5, 28.8, 28.7, 22.7, 19.7, 14.2; HRMS (EI) $\mathrm{m} / \mathrm{z}$ calcd. for: [M] ${ }^{+} 361.2042, \mathrm{~m} / \mathrm{z}$ found: 361.2046.

\section{4-Fluoro-2-oct-1-ynyl-1H-indole (2l)}<smiles>Nc1cccc(F)c1C=C(Br)Br</smiles>

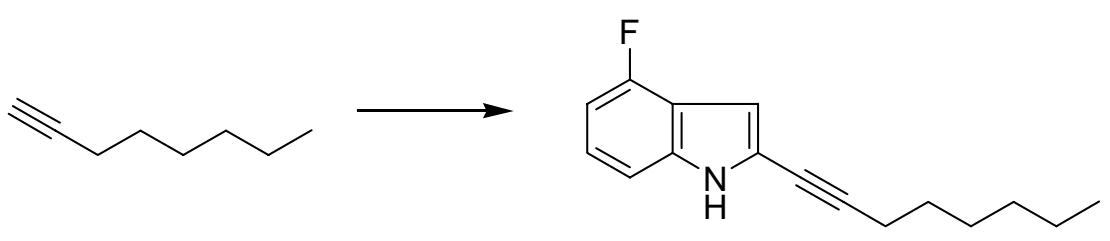

A carousel reaction tube $(24 \times 150 \mathrm{~mm})$ was charged with 2-(2,2-dibromovinyl)3-fluorophenylamine (150 mg, $0.51 \mathrm{mmol}), 10 \% \mathrm{Pd}-\mathrm{C}$ (10.6 mg, $0.010 \mathrm{mmol}, 2 \mathrm{~mol} \%$ ), $\mathrm{P}(p-\mathrm{MeOPh})_{3}(7.1 \mathrm{mg}, 0.020 \mathrm{mmol}, 4 \mathrm{~mol} \%)$, and $\mathrm{CuI}(2.0 \mathrm{mg}, 0.010 \mathrm{mmol}, 2 \mathrm{~mol} \%)$, and was evacuated and purged with argon three times. To this mixture were added toluene $\left(3 \mathrm{~mL}\right.$, degassed), $i \operatorname{Pr}_{2} \mathrm{NH}(180 \mu \mathrm{L}, 1.25 \mathrm{mmol})$ and 1-octynye $(110 \mu \mathrm{L}, 0.75$ mmol), and then heated to $100{ }^{\circ} \mathrm{C}$ with stirring for $24 \mathrm{~h}$. The reaction mixture was then cooled to $\mathrm{rt}$ and $\mathrm{H}_{2} \mathrm{O}(10 \mathrm{~mL})$ added. The mixture was extracted with EtOAc $(2 \times 15$ $\mathrm{mL}$ ), and combined extracts were washed with sat. $\mathrm{NH}_{4} \mathrm{Cl}$ and brine, then dried and solvent was removed in vacuo. The resulting crude material was purified by flash chromatography eluting with 5\% EtOAc in hexane to afford $\mathbf{2 l}$ as a pale yellow oil (88.0 $\mathrm{mg}, 72 \%)$. IR $\left(\mathrm{CHCl}_{3}\right) \vee 3412,2925,2856,1582,1534,1507,1351,1237,1168,1036$ $\mathrm{cm}^{-1} ;{ }^{1} \mathrm{H}-\mathrm{NMR}\left(\mathrm{CDCl}_{3}\right) \delta: 8.15(1 \mathrm{H}, \mathrm{s}), 7.15-7.02(2 \mathrm{H}, \mathrm{m}), 6.80-6.69(2 \mathrm{H}, \mathrm{m}), 2.44(2 \mathrm{H}$, $\mathrm{t}, J=7.0 \mathrm{~Hz}), 1.68-1.24(8 \mathrm{H}, \mathrm{m}), 0.91(3 \mathrm{H}, \mathrm{t}, J=6.9 \mathrm{~Hz}) ;{ }^{13} \mathrm{C} \mathrm{NMR}\left(75 \mathrm{MHz}, \mathrm{CDCl}_{3}\right) \delta$ $156.1\left(J_{\mathrm{CF}}=246.0 \mathrm{~Hz}\right), 138.1\left(J_{\mathrm{CF}}=10.5 \mathrm{~Hz}\right), 123.6\left(J_{\mathrm{CF}}=7.5 \mathrm{~Hz}\right), 119.9,117.2,106.8$ $\left(J_{\mathrm{CF}}=3.8 \mathrm{~Hz}\right), 105.1\left(J_{\mathrm{CF}}=18.8 \mathrm{~Hz}\right), 103.5,94.5,72.6,31.5,28.8,28.6,22.7,19.7$, 14.2; HRMS (ESI) $\mathrm{m} / \mathrm{z}$ calcd. for: $[\mathrm{M}+\mathrm{H}]^{+} 244.1495, \mathrm{~m} / \mathrm{z}$ found: 244.1496.

\section{2-Oct-1-ynyl-1H-indole-5-carboxylic acid methyl ester (2m)}

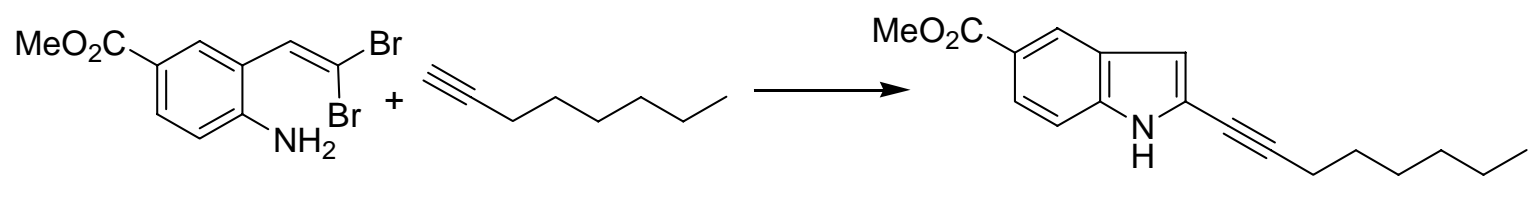

A carousel reaction tube $(24 \times 150 \mathrm{~mm})$ was charged with 4-amino-3-(2,2-dibromovinyl)benzoic acid methyl ester (110 mg, $0.33 \mathrm{mmol}), 10 \%$ Pd-C (17.5 mg, $0.017 \mathrm{mmol}, 5 \mathrm{~mol} \%), \mathrm{P}(p-\mathrm{MeOPh})_{3}(9.2 \mathrm{mg}, 0.026 \mathrm{mmol}, 8 \mathrm{~mol} \%)$, 
and $\mathrm{CuI}$ (2.7 mg, $0.014 \mathrm{mmol}, 4 \mathrm{~mol} \%$ ), and was evacuated and purged with argon three times. To this mixture were added toluene ( $3 \mathrm{~mL}$, degassed), ${ }^{2} \operatorname{Pr}_{2} \mathrm{NH}(140 \mu \mathrm{L}, 1.00$ mmol) and 1-octynye ( $80 \mu \mathrm{L}, 0.54 \mathrm{mmol}$ ), and then heated to $100{ }^{\circ} \mathrm{C}$ with stirring for 24 h. The reaction mixture was then cooled to $\mathrm{rt}$ and $\mathrm{H}_{2} \mathrm{O}(10 \mathrm{~mL})$ added. The mixture was extracted with EtOAc $(2 \times 15 \mathrm{~mL})$, and combined extracts were washed with sat. $\mathrm{NH}_{4} \mathrm{Cl}$ and brine, then dried and solvent was removed in vacuo. The resulting crude material was purified by flash chromatography eluting with $10 \%$ EtOAc in hexane to afford $\mathbf{2 m}$

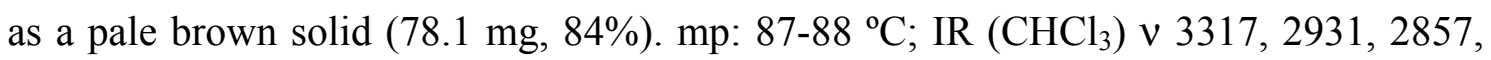
1694, 1615, 1538, 1435, 1347, 1315, 1259, $1156 \mathrm{~cm}^{-1} ;{ }^{1} \mathrm{H}-\mathrm{NMR}\left(\mathrm{CDCl}_{3}\right) \delta: 8.42-8.30$ $(2 \mathrm{H}, \mathrm{m}), 7.90(1 \mathrm{H}, \mathrm{dd}, J=8.6,1.8 \mathrm{~Hz}), 7.29(1 \mathrm{H}, \mathrm{d}, J=8.6 \mathrm{~Hz}), 6.72(1 \mathrm{H}, \mathrm{s}), 3.92(3 \mathrm{H}$, s), $2.44(2 \mathrm{H}, \mathrm{t}, J=7.0 \mathrm{~Hz}), 1.22-1.22(8 \mathrm{H}, \mathrm{m}), 0.91(3 \mathrm{H}, \mathrm{t}, J=6.9 \mathrm{~Hz}) ;{ }^{13} \mathrm{C}$ NMR $(75$ $\left.\mathrm{MHz}, \mathrm{CDCl}_{3}\right) \delta 168.2,138.4,127.6,124.5,123.7,122.6,121.3,110.4,108.6,95.1,72.5$, 52.0, 31.5, 28.8, 28.6, 22.7, 19.7, 14.2; HRMS (EI) $\mathrm{m} / \mathrm{z}$ calcd. for: $[\mathrm{M}]^{+} 283.1572, \mathrm{~m} / \mathrm{z}$ found: 283.1577 .

1-Methyl-2-oct-1-ynyl-1H-indole (2n)

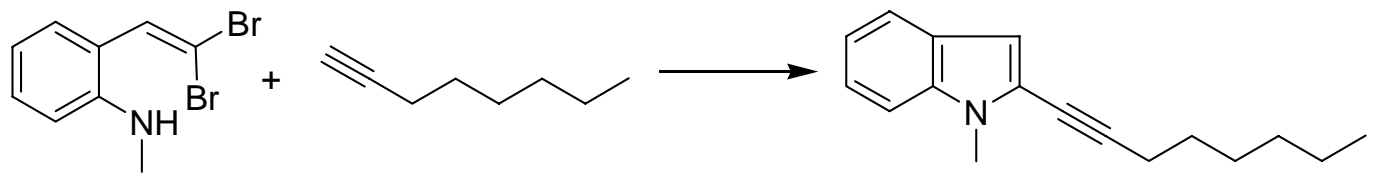

A carousel reaction tube $(24 \times 150 \mathrm{~mm})$ was charged with [2-(2,2-dibromovinyl)phenyl]methylamine (130 mg, $0.45 \mathrm{mmol}), 10 \% \mathrm{Pd}-\mathrm{C}$ (14.2 mg, $0.013 \mathrm{mmol}, 3 \mathrm{~mol} \%), \mathrm{P}(p-\mathrm{MeOPh})_{3}(6.3 \mathrm{mg}, 0.018 \mathrm{mmol}, 4 \mathrm{~mol} \%)$, and $\mathrm{CuI}(1.7 \mathrm{mg}$, $0.0089 \mathrm{mmol}, 2 \mathrm{~mol} \%$ ), and was evacuated and purged with argon three times. To this mixture were added toluene $\left(3 \mathrm{~mL}\right.$, degassed), $i \operatorname{Pr}_{2} \mathrm{NH}(190 \mu \mathrm{L}, 1.34 \mathrm{mmol})$ and 1-octynye (100 $\mu \mathrm{L}, 0.67 \mathrm{mmol})$, and then heated to $100{ }^{\circ} \mathrm{C}$ with stirring for $24 \mathrm{~h}$. The reaction mixture was then cooled to $\mathrm{rt}$ and $\mathrm{H}_{2} \mathrm{O}(10 \mathrm{~mL})$ added. The mixture was extracted with EtOAc $(2 \times 15 \mathrm{~mL})$, and combined extracts were washed with sat. $\mathrm{NH}_{4} \mathrm{Cl}$ and brine, then dried and solvent was removed in vacuo. The resulting crude material was purified by flash chromatography eluting with $1 \% \rightarrow 3 \%$ EtOAc in hexane to afford 2n as a pale yellow oil $(65.1 \mathrm{mg}, 61 \%)$. IR $\left(\mathrm{CHCl}_{3}\right) \vee 2928,2856,1462,1385,1340$, 1313, $1237 \mathrm{~cm}^{-1} ;{ }^{1} \mathrm{H}-\mathrm{NMR}\left(\mathrm{CDCl}_{3}\right) \delta: 7.54(1 \mathrm{H}, \mathrm{dt}, J=7.9,1.0 \mathrm{~Hz}), 7.27-7.18(2 \mathrm{H}, \mathrm{m})$, 7.12-7.05 (1H, m), $6.65(1 \mathrm{H}, \mathrm{s}), 3.77(3 \mathrm{H}, \mathrm{s}), 2.50(2 \mathrm{H}, \mathrm{t}, J=7.0 \mathrm{~Hz}), 1.71-1.59(2 \mathrm{H}, \mathrm{m})$, $1.55-1.26(6 \mathrm{H}, \mathrm{m}), 0.91(3 \mathrm{H}, \mathrm{t}, J=7.0 \mathrm{~Hz}) ;{ }^{13} \mathrm{C} \mathrm{NMR}\left(75 \mathrm{MHz}, \mathrm{CDCl}_{3}\right) \delta 136.8,127.2$, 122.9, 122.4, 120.6, 119.8, 109.2, 106.0, 96.6, 72.2, 31.3, 30.4, 28.6(2C), 22.5, 19.6, 14.0; HRMS (EI) m/z calcd. for: [M] $]^{+} 239.1674, \mathrm{~m} / \mathrm{z}$ found: 239.1678 . 
1-Isopropyl-2-oct-1-ynyl-1H-indole (2o)

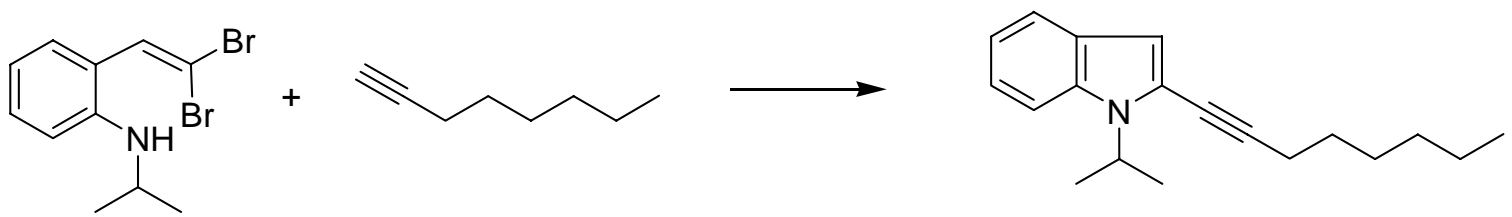

A carousel reaction tube $(24 \times 150 \mathrm{~mm})$ was charged with [2-(2,2-dibromovinyl)phenyl]isopropylamine (160 mg, $0.50 \mathrm{mmol}), 10 \% \mathrm{Pd}-\mathrm{C}$ (26.5 mg, $0.025 \mathrm{mmol}, 5 \mathrm{~mol} \%), \mathrm{P}(p-\mathrm{MeOPh})_{3}(14.1 \mathrm{mg}, 0.040 \mathrm{mmol}, 8 \mathrm{~mol} \%)$, and $\mathrm{CuI}(6.0$ $\mathrm{mg}, 0.020 \mathrm{mmol}, 4 \mathrm{~mol} \%$ ), and was evacuated and purged with argon three times. To this mixture were added toluene $\left(3 \mathrm{~mL}\right.$, degassed), $i \operatorname{Pr}_{2} \mathrm{NH}(210 \mu \mathrm{L}, 1.49 \mathrm{mmol})$ and 1-octynye $(110 \mu \mathrm{L}, 0.75 \mathrm{mmol})$, and then heated to $100{ }^{\circ} \mathrm{C}$ with stirring for $24 \mathrm{~h}$. The reaction mixture was then cooled to $\mathrm{rt}$ and $\mathrm{H}_{2} \mathrm{O}(10 \mathrm{~mL})$ added. The mixture was extracted with EtOAc $(2 \times 15 \mathrm{~mL})$, and combined extracts were washed with sat. $\mathrm{NH}_{4} \mathrm{Cl}$ and brine, then dried and solvent was removed in vacuo. The resulting crude material was purified by flash chromatography eluting 2.5\% EtOAc in hexane to afford $2 \mathrm{o}$ as a pale yellow oil $(80.0 \mathrm{mg}, 60 \%)$. IR $\left(\mathrm{CHCl}_{3}\right) \vee 2929,2856,2361,2340,1454,1408$, 1352, 1313, $1192 \mathrm{~cm}^{-1} ;{ }^{1} \mathrm{H}-\mathrm{NMR}\left(\mathrm{CDCl}_{3}\right) \delta: 7.54(1 \mathrm{H}, \mathrm{d}, J=7.9 \mathrm{~Hz}), 7.42(1 \mathrm{H}, \mathrm{d}, J=$ $8.5 \mathrm{~Hz}), 7.21-7.13(1 \mathrm{H}, \mathrm{m}), 7.10-7.02(1 \mathrm{H}, \mathrm{m}), 6.65(1 \mathrm{H}, \mathrm{s}), 5.04-4.88(1 \mathrm{H}, \mathrm{m}), 2.49$ $(2 \mathrm{H}, \mathrm{t}, J=7.0 \mathrm{~Hz}), 1.70-1.28(8 \mathrm{H}, \mathrm{m}), 1.64(6 \mathrm{H}, \mathrm{d}, J=7.0 \mathrm{~Hz}), 0.91(3 \mathrm{H}, \mathrm{t}, J=6.9 \mathrm{~Hz})$; ${ }^{13} \mathrm{C}$ NMR $\left(75 \mathrm{MHz}, \mathrm{CDCl}_{3}\right) \delta 135.2,128.1,122.1,121.7,121.0,119.6,110.8,107.5$, 96.9, 73.3, 48.3, 31.5, 28.8, 28.7, 22.8, 21.8, 19.9, 14.2; HRMS (EI) m/z calcd. for: $[\mathrm{M}]^{+}$ 267.1987, $\mathrm{m} / \mathrm{z}$ found: 267.1987.

\section{1-Benzyl-2-oct-1-ynyl-1H-indole (2p)}

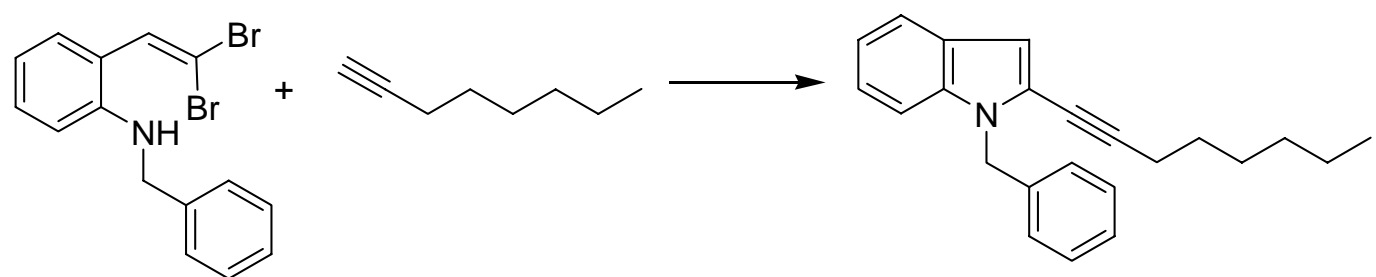

A carousel reaction tube $(24 \times 150 \mathrm{~mm})$ was charged with Benzyl[2-(2,2-dibromovinyl)phenyl]amine (120 mg, $0.33 \mathrm{mmol}), 10 \%$ Pd-C (23.7 mg, $0.022 \mathrm{mmol}, 7 \mathrm{~mol} \%), \mathrm{P}(p-\mathrm{MeOPh})_{3}(11.2 \mathrm{mg}, 0.033 \mathrm{mmol}, 10 \mathrm{~mol} \%)$, and $\mathrm{CuI}(6.0$ $\mathrm{mg}, 0.033 \mathrm{mmol}, 10 \mathrm{~mol} \%$ ), and was evacuated and purged with argon three times. To this mixture were added toluene ( $3 \mathrm{~mL}$, degassed), $i \operatorname{Pr}_{2} \mathrm{NH}(115 \mu \mathrm{L}, 0.82 \mathrm{mmol})$ and 1-octynye ( $72 \mu \mathrm{L}, 0.49 \mathrm{mmol})$, and then heated to $100{ }^{\circ} \mathrm{C}$ with stirring for $24 \mathrm{~h}$. The reaction mixture was then cooled to $\mathrm{rt}$ and $\mathrm{H}_{2} \mathrm{O}(10 \mathrm{~mL})$ added. The mixture was extracted with EtOAc $(2 \times 15 \mathrm{~mL})$, and combined extracts were washed with sat. $\mathrm{NH}_{4} \mathrm{Cl}$ and brine, then dried and solvent was removed in vacuo. The resulting crude material 
was purified by flash chromatography eluting with $2.5 \%$ EtOAc in hexane to afford $2 \mathbf{p}$ as a pale yellow solid (52.6 mg, 51\%). mp: 43-44 ${ }^{\circ} \mathrm{C}$; IR $\left(\mathrm{CHCl}_{3}\right) \vee 3029,2927,2855$, 1454, 1391, 1345, 1312, $1161 \mathrm{~cm}^{-1} ;{ }^{1} \mathrm{H}-\mathrm{NMR}\left(\mathrm{CDCl}_{3}\right) \delta: 7.58-7.54(1 \mathrm{H}, \mathrm{m}), 7.34-7.04$ $(8 \mathrm{H}, \mathrm{m}), 6.73(1 \mathrm{H}, \mathrm{s}), 5.41(2 \mathrm{H}, \mathrm{s}), 2.44(2 \mathrm{H}, \mathrm{t}, J=7.0 \mathrm{~Hz}), 1.62-1.23(8 \mathrm{H}, \mathrm{m}), 0.87(3 \mathrm{H}$, $\mathrm{t}, J=6.5 \mathrm{~Hz}) ;{ }^{13} \mathrm{C}$ NMR $\left(75 \mathrm{MHz}, \mathrm{CDCl}_{3}\right) \delta 138.1,136.5,128.8,127.8,127.5,126.9$, $122.8,120.9,120.3,110.1,106.8,97.1,72.5,48.0,31.5,28.8,28.7,22.7,19.9$, 14.2; HRMS (EI) $\mathrm{m} / \mathrm{z}$ calcd. for: $[\mathrm{M}]^{+} 315.1987, \mathrm{~m} / \mathrm{z}$ found: 315.1981 .

\section{2-Oct-1-ynyl-1-phenyl-1H-indole (2q)}

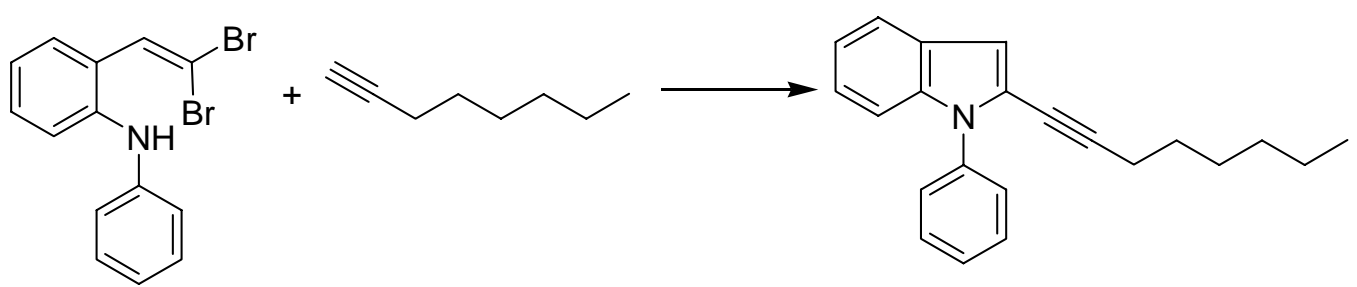

A carousel reaction tube $(24 \times 150 \mathrm{~mm})$ was charged with [2-(2,2-dibromovinyl)phenyl]phenylamine (130 mg, $0.37 \mathrm{mmol}), 10 \% \mathrm{Pd}-\mathrm{C}(3.9 \mathrm{mg}$, $0.0037 \mathrm{mmol}, 1 \mathrm{~mol} \%), \mathrm{P}(p-\mathrm{MeOPh})_{3}(5.2 \mathrm{mg}, 0.015 \mathrm{mmol}, 4 \mathrm{~mol} \%)$, and $\mathrm{CuI}(1.4$ $\mathrm{mg}, 0.0074 \mathrm{mmol}, 2 \mathrm{~mol} \%$ ), and was evacuated and purged with argon three times. To this mixture were added toluene ( $3 \mathrm{~mL}$, degassed), $\operatorname{Pr}_{2} \mathrm{NH}(134 \mu \mathrm{L}, 0.97 \mathrm{mmol})$ and 1-octynye ( $81 \mu \mathrm{L}, 0.55 \mathrm{mmol}$ ), and then heated to $100{ }^{\circ} \mathrm{C}$ with stirring for $24 \mathrm{~h}$. The reaction mixture was then cooled to $\mathrm{rt}$ and $\mathrm{H}_{2} \mathrm{O}(10 \mathrm{~mL})$ added. The mixture was extracted with EtOAc $(2 \times 15 \mathrm{~mL})$, and combined extracts were washed with sat. $\mathrm{NH}_{4} \mathrm{Cl}$ and brine, then dried and solvent was removed in vacuo. The resulting crude material was purified by flash chromatography eluting with $2 \%$ EtOAc in hexane to afford $\mathbf{2 q}$ as a colorless oil $(72.1 \mathrm{mg}, 65 \%)$. IR $\left(\mathrm{CHCl}_{3}\right) \vee 3057,2928,2854,1596,1499,1449,1377$, 1360, 1330, 1314, 1241, 1201, $1144 \mathrm{~cm}^{-1} ;{ }^{1} \mathrm{H}-\mathrm{NMR}\left(\mathrm{CDCl}_{3}\right) \delta: 7.63-7.37(6 \mathrm{H}, \mathrm{m})$, 7.24-7.09 (3H, m), $6.82(1 \mathrm{H}, \mathrm{s}), 2.32(2 \mathrm{H}, \mathrm{t}, J=7.0 \mathrm{~Hz}), 1.39-1.39(2 \mathrm{H}, \mathrm{m}), 1.15-1.14$ $(6 \mathrm{H}, \mathrm{m}), 0.87(3 \mathrm{H}, \mathrm{t}, J=6.9 \mathrm{~Hz}) ;{ }^{13} \mathrm{C} \mathrm{NMR}\left(75 \mathrm{MHz}, \mathrm{CDCl}_{3}\right) \delta 138.0,137.3,129.3$, $129.1,127.8,127.6,127.5,123.2$, 122.9, 120.8, 110.6, 108.4, 96.9, 72.8, 31.5, 28.6, 28.4, 22.7, 19.7, 14.3; HRMS (EI) m/z calcd. for: [M] $]^{+} 301.1831, \mathrm{~m} / \mathrm{z}$ found: 301.1834 . 


\section{Synthesis of Benzofurans}

\section{Starting Materials (3)}

\section{3-(2,2-Dibromovinyl)-4-hydroxybenzoic acid methyl ester (3b)}
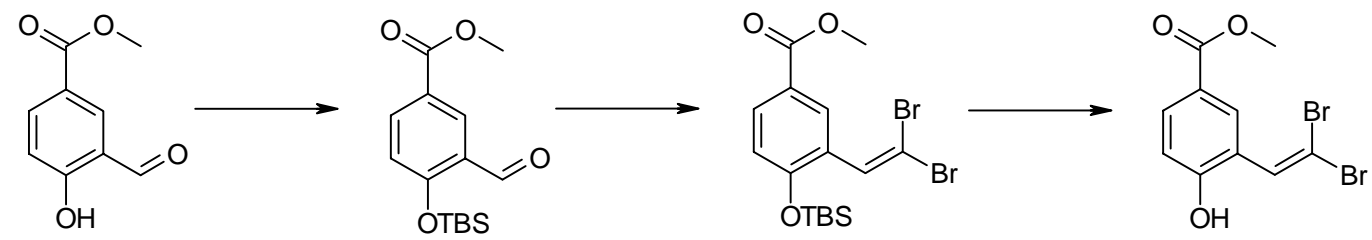

To a solution of methyl 3-formyl-4-hydroxybenzoate (900 $\mathrm{mg}, 5.0 \mathrm{mmol}$ ) and 2,6-lutidine $(0.93 \mathrm{ml}, 8.0 \mathrm{mmol})$ in $\mathrm{CH}_{2} \mathrm{Cl}_{2}(11 \mathrm{~mL})$ was added tert-butyldimethylsilyl trifluoromethanesulfonate $(1.5 \mathrm{~mL}, 6.5 \mathrm{mmol})$ at $0{ }^{\circ} \mathrm{C}$, and the mixture was stirred for 3 $\mathrm{h}$ at rt. Sat. $\mathrm{NaHCO}_{3}(10 \mathrm{~mL})$ was added, and the resulting mixture was extracted with $\mathrm{CH}_{2} \mathrm{Cl}_{2}(2 \times 30 \mathrm{~mL})$. The combined extracts were washed with brine, dried $\left(\mathrm{MgSO}_{4}\right)$ and solvent removed under reduced pressure. The residue was purified by flash chromatography eluting with $10 \% \rightarrow 15 \%$ EtOAc in hexane to afford methyl 4-tert-butyldimethylsilyloxy-3-formylbenzoate as a white solid (1.18 g, 81\%). mp: $52-53{ }^{\circ} \mathrm{C}$; IR $\left(\mathrm{CHCl}_{3}\right) \vee 2952,1725,1692,1607,1491,1272,1118 \mathrm{~cm}^{-1} ;{ }^{1} \mathrm{H}-\mathrm{NMR}$ $\left(\mathrm{CDCl}_{3}\right) \delta: 10.46(1 \mathrm{H}, \mathrm{s}), 8.50(1 \mathrm{H}, \mathrm{d}, J=2.3 \mathrm{~Hz}), 8.14(1 \mathrm{H}, \mathrm{dd}, J=8.8,2.3 \mathrm{~Hz}), 6.93$ $(1 \mathrm{H}, \mathrm{d}, J=8.8 \mathrm{~Hz}), 3.91(3 \mathrm{H}, \mathrm{s}), 1.03(9 \mathrm{H}, \mathrm{s}), 0.32(6 \mathrm{H}, \mathrm{s}) ;{ }^{13} \mathrm{C}$ NMR $(75 \mathrm{MHz}$, DMSO- $\left.d_{6}\right) \delta 193.5,170.2,166.5,140.9,134.9,131.0,127.8,124.3,56.4,29.9$ (3C), 22.6, 0.0 (2C); HRMS (EI) m/z calcd. for: $[\mathrm{M}-\mathrm{tBu}]^{+}$237.0583, $\mathrm{m} / \mathrm{z}$ found: 237.0581 .

To a solution of methyl 4-tert-butyldimethylsilyloxy-3-formylbenzoate (500 mg, 1.70 mmol) in $\mathrm{CH}_{2} \mathrm{Cl}_{2}(50 \mathrm{~mL})$ was added carbon tetrabromide $(5.56 \mathrm{~g}, 16.8 \mathrm{mmol})$ and triphenylphosphine $(8.78 \mathrm{~g}, 33.5 \mathrm{mmol})$ at $0{ }^{\circ} \mathrm{C}$, and the mixture was stirred for $15 \mathrm{~h}$ at rt. $1 \mathrm{M} \mathrm{Na} \mathrm{Na}_{2} \mathrm{O}_{3}(30 \mathrm{~mL})$ was added, and the resulting mixture was extracted with $\mathrm{CH}_{2} \mathrm{Cl}_{2}(2 \times 120 \mathrm{~mL})$. The combined extracts were washed with sat. $\mathrm{NaHCO}_{3}, \mathrm{H}_{2} \mathrm{O}$ and brine, then dried $\left(\mathrm{MgSO}_{4}\right)$ and solvent removed under reduced pressure. The residue was purified by flash chromatography eluting with 5\% EtOAc in hexane to afford 4-(tert-Butyldimethylsilyloxy)-3-(2,2-dibromovinyl)benzoic acid methyl ester as a colorless oil (660 mg, 86\%). IR $\left(\mathrm{CHCl}_{3}\right) \vee$ 2953, 2858, 1732, 1605, 1488, 1286, 1116, $998 \mathrm{~cm}^{-1} ;{ }^{1} \mathrm{H}-\mathrm{NMR}\left(\mathrm{CDCl}_{3}\right) \delta: 8.36-8.33(1 \mathrm{H}, \mathrm{m}), 7.91(1 \mathrm{H}, \mathrm{dd}, J=8.5,2.1 \mathrm{~Hz}), 7.56$ $(1 \mathrm{H}, \mathrm{s}), 6.81(1 \mathrm{H}, \mathrm{d}, J=8.5 \mathrm{~Hz}), 3.89(3 \mathrm{H}, \mathrm{s}), 1.02(9 \mathrm{H}, \mathrm{s}), 0.24(6 \mathrm{H}, \mathrm{s}) ;{ }^{13} \mathrm{C} \mathrm{NMR}(75$ MHz, DMSO- $\left.d_{6}\right) \delta 170.8,161.4,137.4,135.7,135.6,131.7,127.4,123.4,95.6,56.4$, 30.0, 29.9, 22.5, 0.0; HRMS (EI) m/z calcd. for: [M] $]^{+} 448.9792, \mathrm{~m} / \mathrm{z}$ found: 448.9777.

To a solution of 4-(tert-Butyldimethylsilyloxy)-3-(2,2-dibromovinyl)benzoic acid methyl ester $(600 \mathrm{mg}, 1.32 \mathrm{mmol})$ in THF $(45 \mathrm{~mL})$ was added TBAF $(2.0 \mathrm{~mL}, 2.0$ mmol) at $0{ }^{\circ} \mathrm{C}$, and the mixture was stirred for $3 \mathrm{~h}$ at $\mathrm{rt}$. Water $(20 \mathrm{~mL})$ was added, and the resulting mixture was extracted with EtOAc $(2 \times 100 \mathrm{~mL})$. The combined extracts 
were washed with sat. $\mathrm{NH}_{4} \mathrm{Cl}$ and brine, then dried $\left(\mathrm{MgSO}_{4}\right)$ and solvent was removed under reduced pressure. The residue was purified by flash chromatography eluting with $10 \% \rightarrow 30 \%$ EtOAc in hexane to afford $\mathbf{3 b}$ as a white solid (365 mg, 82\%). mp:199-200 ${ }^{\circ} \mathrm{C}$; IR $\left(\mathrm{CHCl}_{3}\right)$ v 3411, 1770, 1683, 1652, $1270 \mathrm{~cm}^{-1} ;{ }^{1} \mathrm{H}-\mathrm{NMR}\left(\mathrm{CDCl}_{3}\right) \delta: 8.40(1 \mathrm{H}, \mathrm{d}$, $J=2.1 \mathrm{~Hz}), 8.10(1 \mathrm{H}, \mathrm{dd}, J=8.4,2.1 \mathrm{~Hz}), 7.68(1 \mathrm{H}, \mathrm{s}), 7.03(1 \mathrm{H}, \mathrm{d}, J=8.4 \mathrm{~Hz}), 5.61$ $(1 \mathrm{H}, \mathrm{s}), 4.06(3 \mathrm{H}, \mathrm{s}) ;{ }^{13} \mathrm{C} \mathrm{NMR}\left(75 \mathrm{MHz}, \mathrm{DMSO}-d_{6}\right) \delta 166.3,159.8,133.0,132.0$, 130.9, 122.9, 120.7, 116.2, 91.1, 52.5; HRMS (EI) $\mathrm{m} / \mathrm{z}$ calcd. for: $[\mathrm{M}]^{+} 334.8929, \mathrm{~m} / \mathrm{z}$ found: 334.8912 .

\section{1-(2,2-Dibromovinyl)naphthalen-2-ol (3c)}

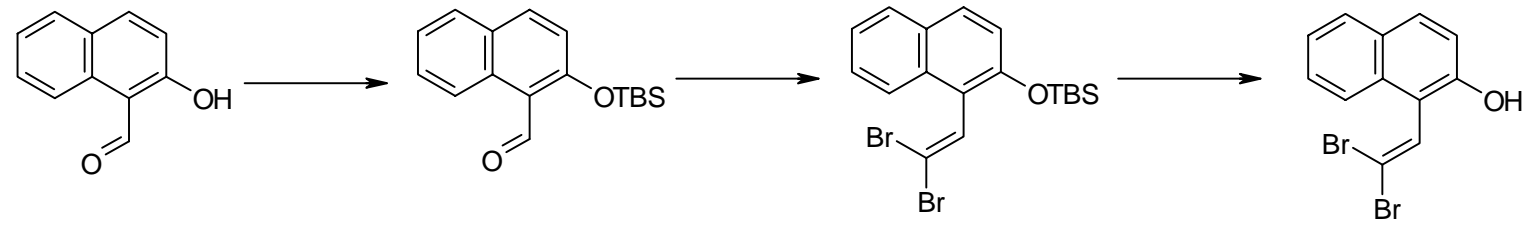

To a solution of 2-hydroxy-1-naphthaldehyde (3.0 g, $17.4 \mathrm{mmol})$ and $\mathrm{Et}_{3} \mathrm{~N}(4.9 \mathrm{ml}, 35$ mmol $)$ in $\mathrm{CH}_{2} \mathrm{Cl}_{2}(50 \mathrm{~mL})$ was added tert-butyldimethylsilyl trifluoromethanesulfonate $(5.2 \mathrm{~mL}, 22.6 \mathrm{mmol})$ at $0{ }^{\circ} \mathrm{C}$, and the mixture was stirred for $3 \mathrm{~h}$ at rt. Sat. $\mathrm{NaHCO}_{3}(30$ $\mathrm{mL})$ was added, and the resulting mixture was extracted with $\mathrm{CH}_{2} \mathrm{Cl}_{2}(2 \times 100 \mathrm{~mL})$. The combined extracts were washed with brine, dried $\left(\mathrm{MgSO}_{4}\right)$ and solvent removed under reduced pressure. The residue was purified by flash chromatography eluting with $10 \%$ EtOAc in hexane to afford 2-(tert-butyldimethylsilyloxy)naphthalene-1-carbaldehyde as a colorless oil $(4.6 \mathrm{~g}, 93 \%)$. IR $\left(\mathrm{CHCl}_{3}\right) \vee 2928,1673,1632,1592,1507,1463,1435$, 1314, 1245, 1155, $1012 \mathrm{~cm}^{-1}$; ${ }^{1} \mathrm{H}-\mathrm{NMR}\left(\mathrm{CDCl}_{3}\right) \delta: 10.87(1 \mathrm{H}, \mathrm{s}), 9.28(1 \mathrm{H}, \mathrm{d}, J=8.8$ $\mathrm{Hz}), 7.95(1 \mathrm{H}, \mathrm{d}, J=9.1 \mathrm{~Hz}), 7.76(1 \mathrm{H}, \mathrm{d}, J=7.3 \mathrm{~Hz}), 7.65-7.57(1 \mathrm{H}, \mathrm{m}), 7.46-7.39$ $(1 \mathrm{H}, \mathrm{m}), 7.06(1 \mathrm{H}, \mathrm{d}, J=8.8 \mathrm{~Hz}), 1.05(9 \mathrm{H}, \mathrm{s}), 0.32(6 \mathrm{H}, \mathrm{t}, J=3.2 \mathrm{~Hz}) ;{ }^{13} \mathrm{C}$ NMR $(75$ MHz, DMSO-d $\left.d_{6}\right) \delta 196.4,165.6,141.1,135.8,133.6,133.0,132.2,129.0$ (2C), 124.7, 123.2, 29.7, 22.5, 0.0; HRMS (EI) $\mathrm{m} / \mathrm{z}$ calcd. for: $[\mathrm{M}]^{+} 287.1467, \mathrm{~m} / \mathrm{z}$ found: 287.1465 .

To a solution of 2-(tert-butyldimethylsilyloxy)naphthalene-1-carbaldehyde (3.2 g, 11.2 mmol) in $\mathrm{CH}_{2} \mathrm{Cl}_{2}(50 \mathrm{~mL})$ was added carbon tetrabromide $(5.56 \mathrm{~g}, 16.8 \mathrm{mmol})$ and triphenylphosphine $(8.78 \mathrm{~g}, 33.5 \mathrm{mmol})$ at $0{ }^{\circ} \mathrm{C}$, and the mixture was stirred for $12 \mathrm{~h}$ at rt. $1 \mathrm{M} \mathrm{Na} \mathrm{S}_{2} \mathrm{O}_{3}(30 \mathrm{~mL})$ was added, and the resulting mixture was extracted with $\mathrm{CH}_{2} \mathrm{Cl}_{2}(2 \times 120 \mathrm{~mL})$. The combined extracts were washed with sat. $\mathrm{NaHCO}_{3}, \mathrm{H}_{2} \mathrm{O}$ and brine, then dried $\left(\mathrm{MgSO}_{4}\right)$ and solvent removed under reduced pressure. The residue was purified by flash chromatography eluting with $2 \%$ EtOAc in hexane to afford tert-butyl-[1-(2,2-dibromovinyl)naphthalen-2-yloxy]dimethylsilane as a colorless oil (4.05 g, 82\%). IR $\left(\mathrm{CHCl}_{3}\right) \vee 3062,2955,2928,2857,1592,1505,1471,1463,1429$, 1377, 1338, 1282, 1250, 1143, $1075 \mathrm{~cm}^{-1} ;{ }^{1} \mathrm{H}-\mathrm{NMR}\left(\mathrm{CDCl}_{3}\right) \delta: 7.56-7.48(3 \mathrm{H}, \mathrm{m}), 7.37$ $(1 \mathrm{H}, \mathrm{s}), 7.25(1 \mathrm{H}, \mathrm{t}, J=6.7 \mathrm{~Hz}), 7.11(1 \mathrm{H}, \mathrm{t}, J=8.2 \mathrm{~Hz}), 6.83(1 \mathrm{H}, \mathrm{d}, J=8.8 \mathrm{~Hz}), 0.82$ 
$(9 \mathrm{H}, \mathrm{s}), 0.00(6 \mathrm{H}, \mathrm{s}) ;{ }^{13} \mathrm{C} \mathrm{NMR}\left(75 \mathrm{MHz}, \mathrm{DMSO}-d_{6}\right) \delta 154.4,138.1,135.5,134.0$, 133.2 (2C), 130.7, 128.5, 128.0, 125.8, 124.9, 98.4, 81.5, 81.0, 80.6, 29.8, 22.2, 0.0; HRMS (EI) $\mathrm{m} / \mathrm{z}$ calcd. for: $[\mathrm{M}]^{+} 439.9823, \mathrm{~m} / \mathrm{z}$ found: 439.9807.

To a solution of tert-butyl-[1-(2,2-dibromovinyl)naphthalen-2-yloxy]dimethylsilane (3.7 $\mathrm{g}, 8.3 \mathrm{mmol})$ in THF $(45 \mathrm{~mL})$ was added TBAF $(11.7 \mathrm{~mL}, 11.7 \mathrm{mmol})$ at $0{ }^{\circ} \mathrm{C}$, and the mixture was stirred for $2 \mathrm{~h}$ at $\mathrm{rt}$. Water $(20 \mathrm{~mL})$ was added, and the resulting mixture was extracted with EtOAc $(2 \times 100 \mathrm{~mL})$. The combined extracts were washed with sat. $\mathrm{NH}_{4} \mathrm{Cl}$ and brine, then dried $\left(\mathrm{MgSO}_{4}\right)$ and solvent was removed under reduced pressure. The residue was purified by flash chromatography eluting with $20 \% \rightarrow 25 \%$ EtOAc in hexane to afford 3c as a white solid $(2.60 \mathrm{~g}, 95 \%)$. mp: $74-75^{\circ} \mathrm{C}$; IR $\left(\mathrm{CHCl}_{3}\right) \vee 3534$, 1620, 1596, 1514, 1466, 1432, 1387, 1346, 1264, 1201, $1141 \mathrm{~cm}^{-1} ;{ }^{1} \mathrm{H}-\mathrm{NMR}\left(\mathrm{CDCl}_{3}\right) \delta$ : $7.80(2 \mathrm{H}, \mathrm{d}, J=8.5 \mathrm{~Hz}), 7.68(1 \mathrm{H}, \mathrm{d}, J=9.1 \mathrm{~Hz}), 7.66(1 \mathrm{H}, \mathrm{s}), 7.51(1 \mathrm{H}, \mathrm{dt}, J=7.9,1.2$ $\mathrm{Hz}), 7.42-7.34(1 \mathrm{H}, \mathrm{m}), 7.17(1 \mathrm{H}, \mathrm{d}, J=9.1 \mathrm{~Hz}), 5.23(1 \mathrm{H}, \mathrm{s}) ;{ }^{13} \mathrm{C}$ NMR $(75 \mathrm{MHz}$, DMSO-d $\left.{ }_{6}\right) \delta 150.0,132.3,131.6,131.0,129.0,128.6,127.3,124.2,123.7,118.0,115.7$, 97.2; HRMS (EI) m/z calcd. for: [M] $]^{+} 325.8940, \mathrm{~m} / \mathrm{z}$ found: 325.8942 .

\section{2-(2,2-Dibromovinyl)-6-methoxyphenol (3d)}

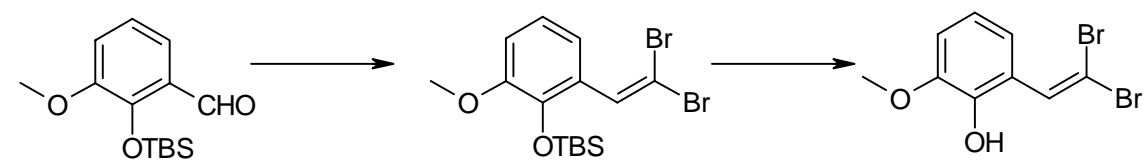

To a solution of 2-hydroxy-3-methoxy-benzaldehyde (5.0 g, $18.7 \mathrm{mmol})$ in $\mathrm{CH}_{2} \mathrm{Cl}_{2}(250$ $\mathrm{mL})$ was added carbon tetrabromide $(9.35 \mathrm{~g}, 28.2 \mathrm{mmol})$ and triphenylphosphine (14.7 $\mathrm{g}, 56.1 \mathrm{mmol})$ at $0{ }^{\circ} \mathrm{C}$, and the mixture was stirred for $24 \mathrm{~h}$ at rt. $1 \mathrm{M} \mathrm{Na}_{2} \mathrm{~S}_{2} \mathrm{O}_{3}(40 \mathrm{~mL})$ was added, and the resulting mixture was extracted with $\mathrm{CH}_{2} \mathrm{Cl}_{2}(2 \times 60 \mathrm{~mL})$. The combined extracts were washed with $\mathrm{H}_{2} \mathrm{O}$ and brine, then dried $\left(\mathrm{MgSO}_{4}\right)$ and solvent removed under reduced pressure. The residue was purified by flash chromatography eluting with $5 \% \quad$ EtOAc in hexane to afford tert-butyl[2-(2,2-dibromovinyl)-6-methoxyphenoxy]dimethylsilane as a colorless oil (7.50 g, 95\%). IR $\left(\mathrm{CHCl}_{3}\right) \vee 2927,2854,1576,1476,1256,1229,1076 \mathrm{~cm}^{-1} ;{ }^{1} \mathrm{H}-\mathrm{NMR}$ $\left(\mathrm{CDCl}_{3}\right) \delta: 7.59(1 \mathrm{H}, \mathrm{s}), 7.24-7.19(1 \mathrm{H}, \mathrm{m}), 6.89(1 \mathrm{H}, \mathrm{d}, J=8.0 \mathrm{~Hz}), 6.84(1 \mathrm{H}, \mathrm{dd}, J=$ 8.0, $1.8 \mathrm{~Hz}), 3.79(3 \mathrm{H}, \mathrm{s}), 1.02(9 \mathrm{H}, \mathrm{s}), 0.17(6 \mathrm{H}, \mathrm{s}) ;{ }^{13} \mathrm{C}$ NMR (75 MHz, DMSO-d 6 ) $\delta$ $150.4,142.6,134.3,127.9,120.8$ (2C), 111.8, 90.0, 55.1, 25.9, 18.7, -4.2; HRMS (EI) $\mathrm{m} / \mathrm{z}$ calcd. for: $[\mathrm{M}-\mathrm{tBu}]^{+}$362.9052, $\mathrm{m} / \mathrm{z}$ found: 362.9047 .

To a solution of tert-butyl[2-(2,2-dibromovinyl)-6-methoxyphenoxy]dimethylsilane (7.5 $\mathrm{g}, 17.7 \mathrm{mmol})$ in THF $(80 \mathrm{~mL})$ was added TBAF $(26 \mathrm{~mL}, 26.0 \mathrm{mmol})$ at $0{ }^{\circ} \mathrm{C}$, and the mixture was stirred for $3 \mathrm{~h}$ at $\mathrm{rt}$. This mixture was then concentrated on a rotary evaporator to approximately $40 \mathrm{ml}$. Water $(20 \mathrm{~mL})$ was added, and the resulting mixture was extracted with EtOAc $(2 \times 60 \mathrm{~mL})$. The combined extracts were washed with sat. 
$\mathrm{NH}_{4} \mathrm{Cl}$ and brine, then dried $\left(\mathrm{MgSO}_{4}\right)$ and solvent was removed under reduced pressure. The residue was purified by flash chromatography eluting with $20 \%$ EtOAc in hexane to afford 3d as a white solid (4.42 g, 81\%). mp: 43-44 ${ }^{\circ} \mathrm{C}$; IR $\left(\mathrm{CHCl}_{3}\right) \vee 3504,2935$, 2837, 1613, 1473, 1359, 1258, $1068 \mathrm{~cm}^{-1} ;{ }^{1} \mathrm{H}-\mathrm{NMR}\left(\mathrm{CDCl}_{3}\right) \delta: 7.65(1 \mathrm{H}, \mathrm{s}), 7.38-7.30$ $(1 \mathrm{H}, \mathrm{m}), 6.89-6.82(2 \mathrm{H}, \mathrm{m}), 5.85(1 \mathrm{H}, \mathrm{s}), 3.90(3 \mathrm{H}, \mathrm{s}) ;{ }^{13} \mathrm{C}$ NMR $\left(75 \mathrm{MHz}, \mathrm{DMSO}-d_{6}\right) \delta$ 146.6, 143.5, 132.1, 122.0, 120.9, 119.4, 110.8, 90.3, 56.3; HRMS (EI) m/z calcd. for: $[\mathrm{M}]^{+} 305.8891, \mathrm{~m} / \mathrm{z}$ found: 305.8898 .

\section{Benzofurans (4)}

\section{2-Oct-1-ynylbenzofuran (4a)}

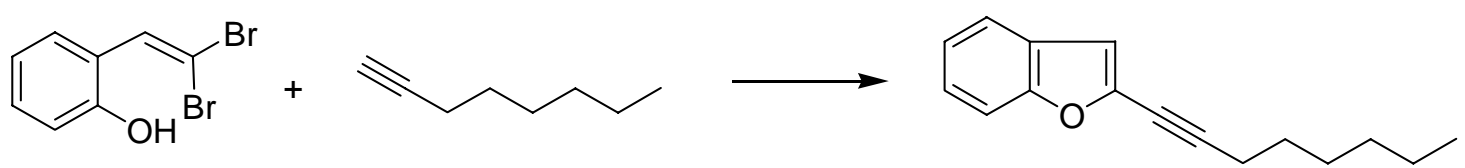

A carousel reaction tube $(24 \times 150 \mathrm{~mm})$ was charged with 2-(2,2-dibromovinyl)phenol (115 mg, $0.41 \mathrm{mmol}), 10 \% \mathrm{Pd}-\mathrm{C}$ (4.4 mg, $0.0041 \mathrm{mmol}, 1 \mathrm{~mol} \%), \mathrm{P}(p-\mathrm{MeOPh})_{3}(5.8$ $\mathrm{mg}, 0.017 \mathrm{mmol}, 4 \mathrm{~mol} \%$ ), and $\mathrm{CuI}$ (1.6 $\mathrm{mg}, 0.0083 \mathrm{mmol}, 2 \mathrm{~mol} \%$ ), and was evacuated and purged with argon three times. To this mixture were added toluene $(2 \mathrm{~mL}$, degassed), $\mathrm{H}_{2} \mathrm{O}(1 \mathrm{~mL}$, degassed $), i \mathrm{Pr}_{2} \mathrm{NH}(145 \mu \mathrm{L}, 1.03 \mathrm{mmol})$ and 3-ethynylpyridine $\left(83 \mu \mathrm{L}, 0.75 \mathrm{mmol}\right.$ ), and then heated to $100{ }^{\circ} \mathrm{C}$ with stirring for $12 \mathrm{~h}$. The reaction mixture was then cooled to $\mathrm{rt}$ and $\mathrm{H}_{2} \mathrm{O}(10 \mathrm{~mL})$ added. The mixture was extracted with EtOAc $(2 \times 15 \mathrm{~mL})$, and combined extracts were washed with sat. $\mathrm{NH}_{4} \mathrm{Cl}$ and brine, then dried and solvent was removed in vacuo. The resulting crude material was purified by flash chromatography eluting with $2 \%$ EtOAc in hexane to afford 4 a as a white solid (74.5 mg, 80\%). IR $\left(\mathrm{CHCl}_{3}\right) \vee 2927,2855,2230,1567,1448,1349,1304,1253,1196$, 1156, 1141, 1107, $1009 \mathrm{~cm}^{-1}$; ${ }^{1} \mathrm{H}-\mathrm{NMR}\left(\mathrm{CDCl}_{3}\right) \delta: 7.55-7.49(1 \mathrm{H}, \mathrm{m}), 7.45-7.40(1 \mathrm{H}$, m), 7.33-7.18 $(2 \mathrm{H}, \mathrm{m}), 6.81(1 \mathrm{H}, \mathrm{s}), 2.48(2 \mathrm{H}, \mathrm{t}, J=7.0 \mathrm{~Hz}), 1.71-1.24(8 \mathrm{H}, \mathrm{m}), 0.91$ $(3 \mathrm{H}, \mathrm{t}, J=6.9 \mathrm{~Hz}) ;{ }^{13} \mathrm{C}$ NMR $\left(75 \mathrm{MHz}, \mathrm{DMSO}-d_{6}\right) \delta 139.5,125.2,123.2,121.1,111.2$, 110.2, 97.3, 71.4, 31.5, 28.8, 28.4, 22.7, 19.8, 14.2; HRMS (EI) m/z calcd. for: $[\mathrm{M}]^{+}$ 226.1358, $\mathrm{m} / \mathrm{z}$ found: 226.1356 .

Benzofuran-2-ylethynyltrimethylsilane (4b)

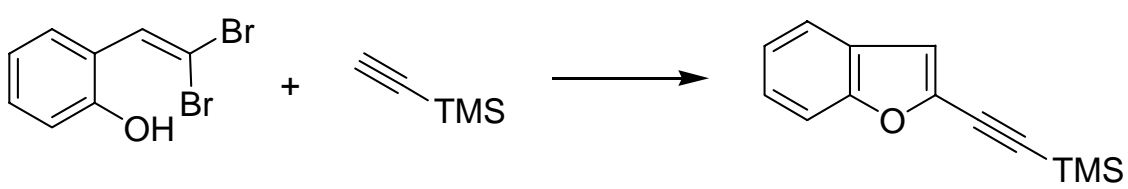

A carousel reaction tube $(24 \times 150 \mathrm{~mm})$ was charged with 2-(2,2-dibromovinyl)phenol 
(140 mg, $0.50 \mathrm{mmol}), 10 \% \mathrm{Pd}-\mathrm{C}(10.6 \mathrm{mg}, 0.01 \mathrm{mmol}, 1 \mathrm{~mol} \%), \mathrm{P}(p-\mathrm{MeOPh})_{3}(7.1 \mathrm{mg}$, $0.02 \mathrm{mmol}, 4 \mathrm{~mol} \%$ ), and $\mathrm{CuI}(1.9 \mathrm{mg}, 0.010 \mathrm{mmol}, 2 \mathrm{~mol} \%)$, and was evacuated and purged with argon three times. To this mixture were added toluene ( $3 \mathrm{~mL}$, degassed), $i \operatorname{Pr}_{2} \mathrm{NH}(180 \mu \mathrm{L}, 1.28 \mathrm{mmol})$ and trimethylsilylacetylene $(0.71 \mathrm{ml}, 5.0 \mathrm{mmol})$, and then heated to $100{ }^{\circ} \mathrm{C}$ with stirring for $12 \mathrm{~h}$. The reaction mixture was then cooled to $\mathrm{rt}$ and $\mathrm{H}_{2} \mathrm{O}(10 \mathrm{~mL})$ added. The mixture was extracted with EtOAc $(2 \times 15 \mathrm{~mL})$, and combined extracts were washed with sat. $\mathrm{NH}_{4} \mathrm{Cl}$ and brine, then dried and solvent was removed in vacuo. The resulting crude material was purified by flash chromatography eluting with $0.2 \%$ EtOAc in hexane to afford $\mathbf{4 b}$ as a colorless oil $(50.0 \mathrm{mg}, 47 \%)$. IR $\left(\mathrm{CHCl}_{3}\right) \mathrm{v}$ 2960, 2900, 2160, 1557, 1448, 1413, 1352, 1307, 1252, 1181, 1108, $1010 \mathrm{~cm}^{-1}$; ${ }^{1} \mathrm{H}-\mathrm{NMR}\left(\mathrm{CDCl}_{3}\right) \delta: 7.25(1 \mathrm{H}, \mathrm{d}, J=7.6 \mathrm{~Hz}), 7.14(1 \mathrm{H}, \mathrm{d}, J=8.5 \mathrm{~Hz}), 7.07-6.90(2 \mathrm{H}$, m), $6.65(1 \mathrm{H}, \mathrm{s}), 0.03(9 \mathrm{H}, \mathrm{t}, J=11.7 \mathrm{~Hz}) ;{ }^{13} \mathrm{C}$ NMR $\left(75 \mathrm{MHz}, \mathrm{DMSO}-d_{6}\right) \delta 155.0$, 138.8, 127.7, 126.1, 123.6, 121.6, 112.3, 111.6, 102.2, 94.6, 0.0; HRMS (EI) m/z calcd. for: $[\mathrm{M}]^{+} 214.0814, \mathrm{~m} / \mathrm{z}$ found: 214.0820 .

(3-Benzofuran-2-yl)prop-2-yn-1-ol (4c)

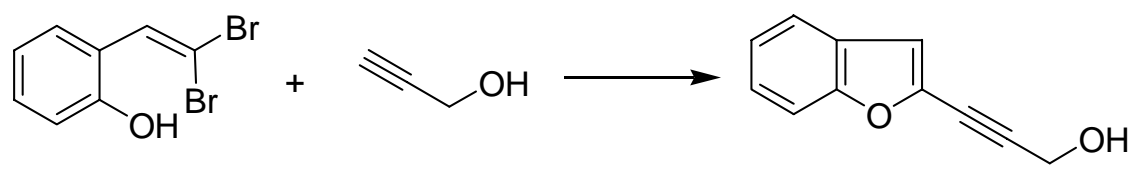

A carousel reaction tube $(24 \times 150 \mathrm{~mm})$ was charged with 2-(2,2-dibromovinyl)phenol (120 mg, $0.43 \mathrm{mmol}), 10 \% \mathrm{Pd}-\mathrm{C}$ (4.6 mg, $0.0043 \mathrm{mmol}, 1 \mathrm{~mol} \%), \mathrm{P}(p-\mathrm{MeOPh})_{3}(6.0$

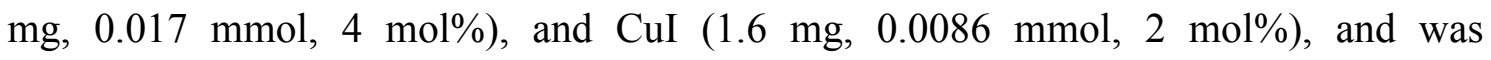
evacuated and purged with argon three times. To this mixture were added toluene $(2 \mathrm{~mL}$, degassed $), \mathrm{H}_{2} \mathrm{O}(1 \mathrm{~mL}$, degassed $), i \mathrm{Pr}_{2} \mathrm{NH}(157 \mu \mathrm{L}, 1.12 \mathrm{mmol})$ and propargyl alcohol $(0.10 \mathrm{ml}, 1.30 \mathrm{mmol})$, and then heated to $100{ }^{\circ} \mathrm{C}$ with stirring for $12 \mathrm{~h}$. The reaction mixture was then cooled to $\mathrm{rt}$ and $\mathrm{H}_{2} \mathrm{O}(10 \mathrm{~mL})$ added. The mixture was extracted with EtOAc $(2 \times 15 \mathrm{~mL})$, and combined extracts were washed with sat. $\mathrm{NH}_{4} \mathrm{Cl}$ and brine, then dried and solvent was removed in vacuo. The resulting crude material was purified by flash chromatography eluting with $33 \%$ EtOAc in hexane to afford $\mathbf{4 c}$ as a colorless oil $(36.0 \mathrm{mg}, 49 \%)$. IR $\left(\mathrm{CHCl}_{3}\right) \vee 3350,2224,1566,1448,1349,1306,1265,1189$, 1157, 1141, 1108, $1027 \mathrm{~cm}^{-1}$; ${ }^{1} \mathrm{H}-\mathrm{NMR}\left(\mathrm{CDCl}_{3}\right) \delta: 7.55(1 \mathrm{H}, \mathrm{d}, J=7.6 \mathrm{~Hz}), 7.45(1 \mathrm{H}, \mathrm{d}$, $J=7.3 \mathrm{~Hz}), 7.38-7.20(2 \mathrm{H}, \mathrm{m}), 6.95(1 \mathrm{H}, \mathrm{s}), 4.56(2 \mathrm{H}, \mathrm{d}, J=6.0 \mathrm{~Hz}), 1.80(1 \mathrm{H}, \mathrm{t}, J=$ $6.0 \mathrm{~Hz}) ;{ }^{13} \mathrm{C}$ NMR (75 MHz, DMSO-d $\left.{ }_{6}\right) \delta 155.0,137.9,127.6,125.9,123.5,121.5$, 112.2, 111.5, 93.5, 76.5, 51.7; HRMS (EI) $\mathrm{m} / \mathrm{z}$ calcd. for: $[\mathrm{M}]^{+} 172.0532, \mathrm{~m} / \mathrm{z}$ found: 172.0524 . 
[(3-Benzofuran-2-yl)prop-2-ynyloxy]-tert-butyldiphenylsilane (4d)

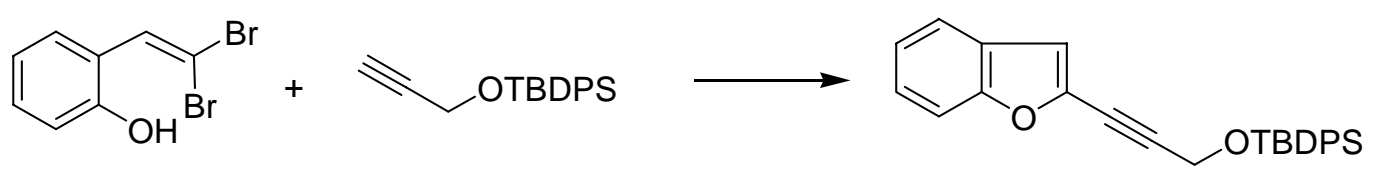

A carousel reaction tube $(24 \times 150 \mathrm{~mm})$ was charged with 2-(2,2-dibromovinyl)phenol (140 mg, $0.50 \mathrm{mmol}), 10 \% \mathrm{Pd}-\mathrm{C}(5.3 \mathrm{mg}, 0.0050 \mathrm{mmol}, 1 \mathrm{~mol} \%), \mathrm{P}(p-\mathrm{MeOPh})_{3}(7.1$ $\mathrm{mg}, 0.020 \mathrm{mmol}, 4 \mathrm{~mol} \%)$, and $\mathrm{CuI}(1.9 \mathrm{mg}, 0.010 \mathrm{mmol}, 2 \mathrm{~mol} \%$ ), and was evacuated and purged with argon three times. To this mixture were added toluene ( $2 \mathrm{~mL}$, degassed),

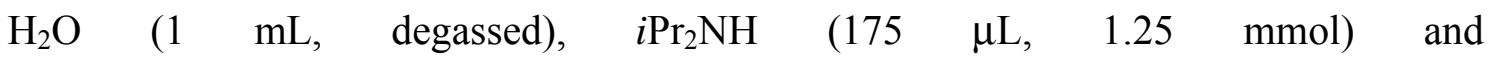
tert-butyldiphenylprop-2-ynyloxysilane $(221 \mathrm{mg}, 0.75 \mathrm{mmol})$, and then heated to 100 ${ }^{\circ} \mathrm{C}$ with stirring for $12 \mathrm{~h}$. The reaction mixture was then cooled to $\mathrm{rt}$ and $\mathrm{H}_{2} \mathrm{O}(10 \mathrm{~mL})$ added. The mixture was extracted with EtOAc $(2 \times 15 \mathrm{~mL})$, and combined extracts were washed with sat. $\mathrm{NH}_{4} \mathrm{Cl}$ and brine, then dried and solvent was removed in vacuo. The resulting crude material was purified by flash chromatography eluting with $4 \%$ EtOAc in hexane to afford $\mathbf{4 d}$ as a colorless oil $(165 \mathrm{mg}, 80 \%)$. IR $\left(\mathrm{CHCl}_{3}\right) \vee 3071,2931,2857$, 1589, 1568, 1471, 1463, 1450, 1428, 1372, 1255, 1191, $1113 \mathrm{~cm}^{-1} ;{ }^{1} \mathrm{H}-\mathrm{NMR}\left(\mathrm{CDCl}_{3}\right) \delta$ : 7.78-7.72 (4H, m), 7.57-7.20 (10H, m), $6.86(1 \mathrm{H}, \mathrm{d}, J=0.6 \mathrm{~Hz}), 4.58(2 \mathrm{H}, \mathrm{s}), 1.09(9 \mathrm{H}$, $\mathrm{s}) ;{ }^{13} \mathrm{C}$ NMR (75 MHz, DMSO-d $\left.d_{6}\right) \delta 154.7,138.3,135.6,132.8,129.9,127.8,127.5$, 125.5, 123.2, 121.1, 111.7, 111.2, 93.7, 75.5, 53.0, 26.7, 19.2; HRMS (EI) $\mathrm{m} / \mathrm{z}$ calcd. for: $[\mathrm{M}]^{+} 410.1702, \mathrm{~m} / \mathrm{z}$ found: 410.1704 .

\section{(4-Benzofuran-2-yl)but-3-yn-1-ol (4e)}

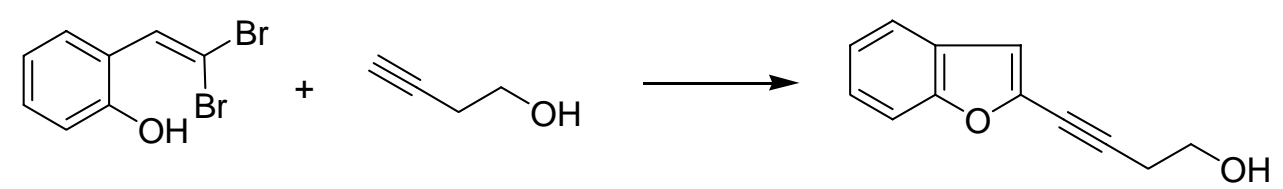

A carousel reaction tube $(24 \times 150 \mathrm{~mm})$ was charged with 2-(2,2-dibromovinyl)phenol (120 mg, $0.43 \mathrm{mmol}), 10 \% \mathrm{Pd}-\mathrm{C}$ (4.6 mg, $0.0043 \mathrm{mmol}, 1 \mathrm{~mol} \%), \mathrm{P}(p-\mathrm{MeOPh})_{3}(6.0$ $\mathrm{mg}, 0.017 \mathrm{mmol}, 4 \mathrm{~mol} \%$ ), and $\mathrm{CuI}$ (1.6 $\mathrm{mg}, 0.0086 \mathrm{mmol}, 2 \mathrm{~mol} \%$ ), and was evacuated and purged with argon three times. To this mixture were added toluene $(2 \mathrm{~mL}$, degassed), $\mathrm{H}_{2} \mathrm{O}\left(1 \mathrm{~mL}\right.$, degassed), ${ }^{P_{2}}{ }_{2} \mathrm{NH}(157 \mu \mathrm{L}, 1.12 \mathrm{mmol})$ and 3-butyn-1-ol (50 $\mu \mathrm{L}, 0.65 \mathrm{mmol}$ ), and then heated to $100^{\circ} \mathrm{C}$ with stirring for $12 \mathrm{~h}$. The reaction mixture was then cooled to $\mathrm{rt}$ and $\mathrm{H}_{2} \mathrm{O}(10 \mathrm{~mL})$ added. The mixture was extracted with EtOAc $(2 \times 15 \mathrm{~mL})$, and combined extracts were washed with sat. $\mathrm{NH}_{4} \mathrm{Cl}$ and brine, then dried and solvent was removed in vacuo. The resulting crude material was purified by flash chromatography eluting with $20 \% \rightarrow 30 \%$ EtOAc in hexane to afford $4 \mathbf{e}$ as a pale yellow oil $(50.6 \mathrm{mg}, 63 \%)$. IR $\left(\mathrm{CHCl}_{3}\right) \vee 3376,2886,2234,1566,1471,1448,1350,1304$, $1253,1190,1158,1141,1108,1043,1010 \mathrm{~cm}^{-1} ;{ }^{1} \mathrm{H}-\mathrm{NMR}\left(\mathrm{CDCl}_{3}\right) \delta: 7.54(1 \mathrm{H}, \mathrm{d}, J=$ $8.4 \mathrm{~Hz}), 7.43(1 \mathrm{H}, \mathrm{d}, J=8.4 \mathrm{~Hz}), 7.35-7.19(2 \mathrm{H}, \mathrm{m}), 6.87(1 \mathrm{H}, \mathrm{s}), 3.87(2 \mathrm{H}, \mathrm{q}, J=6.3$ 
$\mathrm{Hz}), 2.78(2 \mathrm{H}, \mathrm{t}, J=6.3 \mathrm{~Hz}), 1.80(1 \mathrm{H}, \mathrm{t}, J=6.3 \mathrm{~Hz}) ;{ }^{13} \mathrm{C}$ NMR $\left(75 \mathrm{MHz}, \mathrm{DMSO}-d_{6}\right) \delta$ 154.7, 138.8, 127.8, 125.6, 123.4, 121.3, 111.3, 111.0, 93.4, 73.2, 60.9, 24.2; HRMS (EI) $\mathrm{m} / \mathrm{z}$ calcd. for: $[\mathrm{M}]^{+} 186.0685, \mathrm{~m} / \mathrm{z}$ found: 186.0681 .

(6-Benzofuran-2-yl)hex-5-ynenitrile (4f)

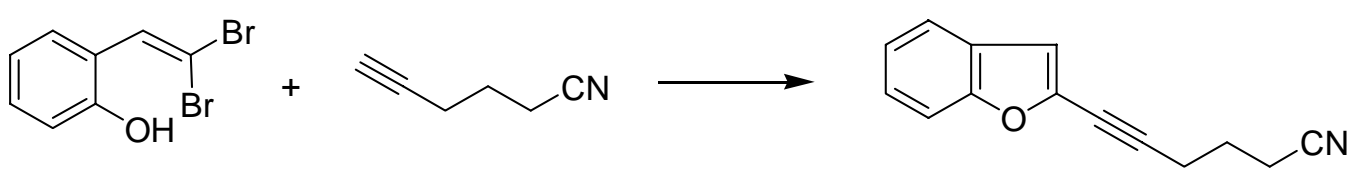

A carousel reaction tube $(24 \times 150 \mathrm{~mm})$ was charged with 2-(2,2-dibromovinyl)phenol (120 mg, $0.43 \mathrm{mmol}), 10 \% \mathrm{Pd}-\mathrm{C}$ (4.6 mg, $0.0043 \mathrm{mmol}, 1 \mathrm{~mol} \%), \mathrm{P}(p-\mathrm{MeOPh})_{3}(6.1$

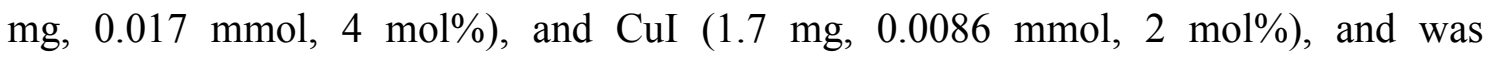
evacuated and purged with argon three times. To this mixture were added toluene $(2 \mathrm{~mL}$, degassed $), \mathrm{H}_{2} \mathrm{O}\left(1 \mathrm{~mL}\right.$, degassed), $i \mathrm{Pr}_{2} \mathrm{NH}(160 \mu \mathrm{L}, 1.18 \mathrm{mmol})$ and 5-hexynenitrile (70 $\mu \mathrm{L}, 0.65 \mathrm{mmol})$, and then heated to $100^{\circ} \mathrm{C}$ with stirring for $12 \mathrm{~h}$. The reaction mixture was then cooled to $\mathrm{rt}$ and $\mathrm{H}_{2} \mathrm{O}(10 \mathrm{~mL})$ added. The mixture was extracted with EtOAc $(2 \times 15 \mathrm{~mL})$, and combined extracts were washed with sat. $\mathrm{NH}_{4} \mathrm{Cl}$ and brine, then dried and solvent was removed in vacuo. The resulting crude material was purified by flash chromatography eluting with $15 \%$ EtOAc in hexane to afford $\mathbf{4 f}$ as a colorless oil (68.5 mg, 76\%). IR $\left(\mathrm{CHCl}_{3}\right)$ v 3061, 2945, 2246, 1732, 1568, 1450, 1428, 1351, 1306, 1253, 1199, 1158, 1142, 1109, $1010 \mathrm{~cm}^{-1}$; ${ }^{1} \mathrm{H}-\mathrm{NMR}\left(\mathrm{CDCl}_{3}\right) \delta: 7.54(1 \mathrm{H}, \mathrm{d}, J=7.6 \mathrm{~Hz}), 7.44$ $(1 \mathrm{H}, \mathrm{d}, J=8.2 \mathrm{~Hz}), 7.37-7.20(2 \mathrm{H}, \mathrm{m}), 6.87(1 \mathrm{H}, \mathrm{s}), 2.70(2 \mathrm{H}, \mathrm{t}, J=6.9 \mathrm{~Hz}), 2.58(2 \mathrm{H}, \mathrm{t}$, $J=6.9 \mathrm{~Hz}), 2.03(2 \mathrm{H}, \mathrm{q}, J=6.9 \mathrm{~Hz}) ;{ }^{13} \mathrm{C} \mathrm{NMR}\left(75 \mathrm{MHz}, \mathrm{DMSO}-d_{6}\right) \delta 154.8,138.6$, $127.7,125.7,123.4,121.3,119.1,111.3,111.2$, 93.6, 73.3, 24.4, 18.9, 16.5; HRMS (EI) $\mathrm{m} / \mathrm{z}$ calcd. for: $[\mathrm{M}]^{+}$209.0841, $\mathrm{m} / \mathrm{z}$ found: 209.0839 .

\section{(2-Phenylethynyl)benzofuran (4g)}

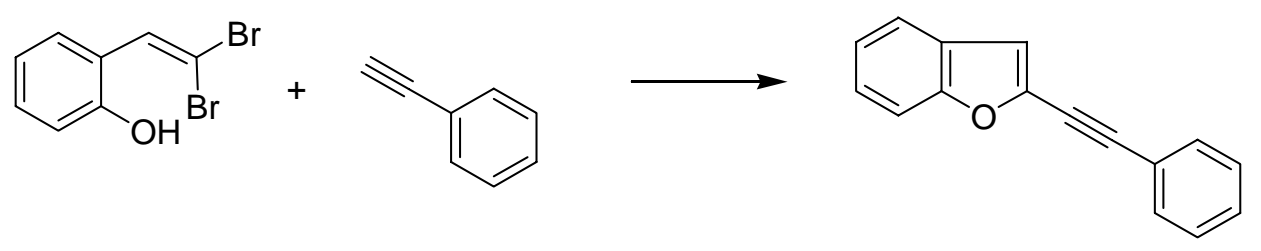

A carousel reaction tube $(24 \times 150 \mathrm{~mm})$ was charged with 2-(2,2-dibromovinyl)phenol (139 mg, $0.50 \mathrm{mmol}), 10 \% \mathrm{Pd}-\mathrm{C}$ (5.3 mg, $0.0043 \mathrm{mmol}, 1 \mathrm{~mol} \%), \mathrm{P}(p-\mathrm{MeOPh})_{3}(7.1$ $\mathrm{mg}, 0.020 \mathrm{mmol}, 4 \mathrm{~mol} \%)$, and $\mathrm{CuI}(2.0 \mathrm{mg}, 0.010 \mathrm{mmol}, 2 \mathrm{~mol} \%)$, and was evacuated and purged with argon three times. To this mixture were added toluene ( $3 \mathrm{~mL}$, degassed), $i \operatorname{Pr}_{2} \mathrm{NH}(176 \mu \mathrm{L}, 1.25 \mathrm{mmol})$ and phenylacetylene $(83 \mu \mathrm{L}, 0.75 \mathrm{mmol})$, and then heated to $100{ }^{\circ} \mathrm{C}$ with stirring for $12 \mathrm{~h}$. The reaction mixture was then cooled to $\mathrm{rt}$ and $\mathrm{H}_{2} \mathrm{O}(10$ $\mathrm{mL})$ added. The mixture was extracted with EtOAc $(2 \times 15 \mathrm{~mL})$, and combined extracts were washed with sat. $\mathrm{NH}_{4} \mathrm{Cl}$ and brine, then dried and solvent was removed in vacuo. 
The resulting crude material was purified by flash chromatography eluting with $1 \%$ EtOAc in hexane to afford $\mathbf{4 g}$ as a white solid $(77.7 \mathrm{mg}, 71 \%) \mathrm{mp}: 71-72{ }^{\circ} \mathrm{C}$; IR $\left(\mathrm{CHCl}_{3}\right) \vee 2926,2857,1595,1499,1450,1377,1313 \mathrm{~cm}^{-1} ;{ }^{1} \mathrm{H}-\mathrm{NMR}\left(\mathrm{CDCl}_{3}\right) \delta$ : 7.62-7.55 (3H, m), $7.48(1 \mathrm{H}, \mathrm{d}, J=7.9 \mathrm{~Hz}), 7.42-7.23(5 \mathrm{H}, \mathrm{m}), 7.02(1 \mathrm{H}, \mathrm{s}) ;{ }^{13} \mathrm{C} \mathrm{NMR}$ $\left(75 \mathrm{MHz}, \mathrm{DMSO}-d_{6}\right) \delta 154.9,138.7,131.6,129.1,128.5,127.7,125.6,123.3,121.8$, 121.2, 111.6, 111.2, 95.0, 79.6; HRMS (EI) m/z calcd. for: $[\mathrm{M}]^{+}$218.0732, m/z found: 218.0732 .

\section{3-Benzofuran-2-ylethynyl-pyridine (4h)}

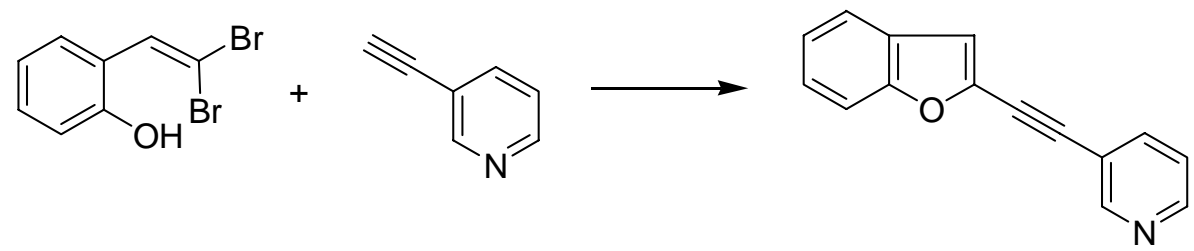

A carousel reaction tube $(24 \times 150 \mathrm{~mm})$ was charged with 2-(2,2-dibromovinyl)phenol (139 mg, $0.50 \mathrm{mmol}), 10 \% \mathrm{Pd}-\mathrm{C}$ (5.3 mg, $0.0043 \mathrm{mmol}, 1 \mathrm{~mol} \%), \mathrm{P}(p-\mathrm{MeOPh})_{3}(7.1$ $\mathrm{mg}, 0.020 \mathrm{mmol}, 4 \mathrm{~mol} \%)$, and $\mathrm{CuI}(2.0 \mathrm{mg}, 0.010 \mathrm{mmol}, 2 \mathrm{~mol} \%)$, and was evacuated and purged with argon three times. To this mixture were added toluene ( $3 \mathrm{~mL}$, degassed), $i \operatorname{Pr}_{2} \mathrm{NH}(180 \mu \mathrm{L}, 1.28 \mathrm{mmol})$ and 3-ethynylpyridine $(77.8 \mathrm{mg}, 0.75 \mathrm{mmol})$, and then heated to $100{ }^{\circ} \mathrm{C}$ with stirring for $12 \mathrm{~h}$. The reaction mixture was then cooled to $\mathrm{rt}$ and $\mathrm{H}_{2} \mathrm{O}(10 \mathrm{~mL})$ added. The mixture was extracted with EtOAc $(2 \times 15 \mathrm{~mL})$, and combined extracts were washed with sat. $\mathrm{NH}_{4} \mathrm{Cl}$ and brine, then dried and solvent was removed in vacuo. The resulting crude material was purified by flash chromatography eluting with $25 \% \rightarrow 30 \%$ EtOAc in hexane to afford $\mathbf{4 h}$ as a white solid $(67.3 \mathrm{mg}, 61 \%)$. mp: $75-76$ ${ }^{\circ} \mathrm{C}$; IR $\left(\mathrm{CHCl}_{3}\right) \vee 2357,1558,1506,1472,1447,1407,1257,1169,947 \mathrm{~cm}^{-1}$; ${ }^{1} \mathrm{H}-\mathrm{NMR}$ $\left(\mathrm{CDCl}_{3}\right) \delta: 8.83(1 \mathrm{H}, \mathrm{s}), 8.60(1 \mathrm{H}, \mathrm{s}), 7.86(1 \mathrm{H}, \mathrm{dt}, J=7.9,1.8 \mathrm{~Hz}), 7.60(1 \mathrm{H}, \mathrm{d}, J=7.6$ $\mathrm{Hz}), 7.49(1 \mathrm{H}, \mathrm{d}, J=8.2 \mathrm{~Hz}), 7.40-7.23(3 \mathrm{H}, \mathrm{m}), 7.07(1 \mathrm{H}, \mathrm{s}) ;{ }^{13} \mathrm{C}$ NMR $(75 \mathrm{MHz}$, DMSO-d $\left.d_{6}\right) \delta 155.2,152.4,149.5,138.6,127.7,126.2,123.6,123.3,121.6,112.7,111.5$, 91.8, 83.1; HRMS (EI) $\mathrm{m} / \mathrm{z}$ calcd. for: $[\mathrm{M}]^{+} 219.0684, \mathrm{~m} / \mathrm{z}$ found: 219.0683 .

(8R,9S,13S,14S,17S)-17-Benzofuran-2-ylethynyl-13-methyl-7,8,9,11,12,13,14,15,16, 17-decahydro-6H-cyclopenta[a]phenanthrene-3,17-diol (4i)<smiles>CC#C[C@]1(O)CC[C@H]2[C@@H]3CCc4cc(O)ccc4[C@H]3CC[C@@]2(C)[C@@]1(C)C#CC</smiles> 
A carousel reaction tube $(24 \times 150 \mathrm{~mm})$ was charged with 2-(2,2-dibromovinyl)phenol (100 mg, $0.36 \mathrm{mmol}), 10 \% \mathrm{Pd}-\mathrm{C}$ (3.8 mg, $0.0036 \mathrm{mmol}, 1 \mathrm{~mol} \%), \mathrm{P}(p-\mathrm{MeOPh})_{3}(5.1$ $\mathrm{mg}, 0.014 \mathrm{mmol}, 4 \mathrm{~mol} \%$ ), and $\mathrm{CuI}$ (1.4 mg, $0.0072 \mathrm{mmol}, 2 \mathrm{~mol} \%)$, and was evacuated and purged with argon three times. To this mixture were added toluene $(2 \mathrm{~mL}$, degassed $), \quad \mathrm{H}_{2} \mathrm{O} \quad(1 \mathrm{~mL}$, degassed $), \quad{ }^{2} \operatorname{Pr}_{2} \mathrm{NH} \quad(180 \mu \mathrm{L}, 1.28 \mathrm{mmol})$ and 17 - $\alpha$-ethynylestradiol (148 mg, $0.54 \mathrm{mmol}$ ), and then heated to $100{ }^{\circ} \mathrm{C}$ with stirring for $12 \mathrm{~h}$. The reaction mixture was then cooled to $\mathrm{rt}$ and $\mathrm{H}_{2} \mathrm{O}(10 \mathrm{~mL})$ added. The mixture was extracted with EtOAc $(2 \times 15 \mathrm{~mL})$, and combined extracts were washed with sat. $\mathrm{NH}_{4} \mathrm{Cl}$ and brine, then dried and solvent was removed in vacuo. The resulting crude material was purified by flash chromatography eluting with $35 \% \rightarrow 40 \%$ EtOAc in hexane to afford $4 \mathbf{i}$ as a white solid $(102.0 \mathrm{mg}, 69 \%) . \mathrm{mp}: 208-210{ }^{\circ} \mathrm{C}$; IR $\left(\mathrm{CHCl}_{3}\right) \mathrm{v}$ 3378, 3017, 2913, 2398, 1578, 1493, 1436, 1358, 1216, 1134, 1108, 1059, $1006 \mathrm{~cm}^{-1}$; ${ }^{1} \mathrm{H}-\mathrm{NMR}\left(\mathrm{DMSO}-d_{6}\right) \delta: 8.98(1 \mathrm{H}, \mathrm{s}), 7.61(1 \mathrm{H}, \mathrm{d}, J=7.0 \mathrm{~Hz}), 7.55(1 \mathrm{H}, \mathrm{d}, J=8.5 \mathrm{~Hz})$, 7.39-7.19 (3H, m), $7.05(1 \mathrm{H}, \mathrm{d}, J=8.5 \mathrm{~Hz}), 6.50(1 \mathrm{H}, \mathrm{dd}, J=8.4,2.4 \mathrm{~Hz}), 6.42(1 \mathrm{H}, \mathrm{d}$, $J=2.4 \mathrm{~Hz}), 5.74(1 \mathrm{H}, \mathrm{s}), 2.70(2 \mathrm{H}, \mathrm{s}), 2.38-2.18(2 \mathrm{H}, \mathrm{m}), 2.15-1.90(2 \mathrm{H}, \mathrm{m}), 1.86-1.56$ $(5 \mathrm{H}, \mathrm{m}), 1.48-1.16(4 \mathrm{H}, \mathrm{m}), 0.92(3 \mathrm{H}, \mathrm{s}) ;{ }^{13} \mathrm{C}$ NMR (75 MHz, DMSO-d 6 ) $\delta 155.6,154.7$, 138.6, 137.8, 130.8, 127.9, 126.8, 126.4, 124.1, 122.0, 115.6, 113.4, 111.9, 111.7, 101.9, 79.5, 75.5, 50.2, 48.0, 43.9, 33.6, 29.8, 27.6, 26.8, 23.3, 13.5; HRMS (EI) m/z calcd. for: $[\mathrm{M}]^{+}$412.2048, m/z found: 412.2038; Anal. calcd. for $\mathrm{C}_{28} \mathrm{H}_{28} \mathrm{O}_{3} \square 0.25 \mathrm{H}_{2} \mathrm{O}: \mathrm{C}$ 80.64, H 6.89, found: C 80.94, H 6.75.

\section{2-Oct-1-ynyl-benzofuran-5-carboxylic acid methyl ester (4j)}

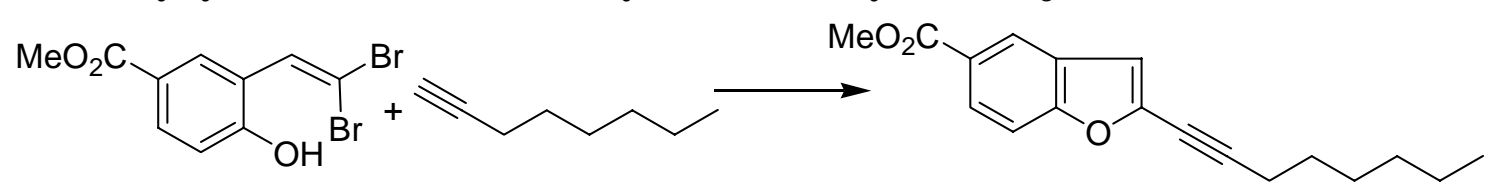

A carousel reaction tube $(24 \times 150 \mathrm{~mm})$ was charged with 3-(2,2-dibromovinyl)4-hydroxybenzoic acid methyl ester (105 mg, $0.31 \mathrm{mmol}), 10 \%$ Pd-C (6.6 mg, 0.0062 mmol, $2 \mathrm{~mol} \%), \mathrm{P}(p-\mathrm{MeOPh})_{3}(8.8 \mathrm{mg}, 0.025 \mathrm{mmol}, 8 \mathrm{~mol} \%)$, and $\mathrm{CuI}(2.4 \mathrm{mg}, 0.013$ mmol, $4 \mathrm{~mol} \%$ ), and was evacuated and purged with argon three times. To this mixture were added toluene ( $2 \mathrm{~mL}$, degassed), $\mathrm{H}_{2} \mathrm{O}$ ( $1 \mathrm{~mL}$, degassed $), i \mathrm{Pr}_{2} \mathrm{NH}(123 \mu \mathrm{L}, 0.875$ mmol) and 1-octyne ( $70 \mu \mathrm{L}, 0.47 \mathrm{mmol})$, and then heated to $100{ }^{\circ} \mathrm{C}$ with stirring for 12 $h$. The reaction mixture was then cooled to $\mathrm{rt}$ and $\mathrm{H}_{2} \mathrm{O}(10 \mathrm{~mL})$ added. The mixture was extracted with EtOAc $(2 \times 15 \mathrm{~mL})$, and combined extracts were washed with sat. $\mathrm{NH}_{4} \mathrm{Cl}$ and brine, then dried and solvent was removed in vacuo. The resulting crude material was purified by flash chromatography eluting with 3\% EtOAc in hexane to afford $\mathbf{4 j}$ as a colorless oil $(82.4 \mathrm{mg}, 93 \%)$. IR $\left(\mathrm{CHCl}_{3}\right) \vee 2929,2234,1732,1615,1574,1435,1348$, 1311, 1197, 1148, 1116, $1087 \mathrm{~cm}^{-1} ;{ }^{1} \mathrm{H}-\mathrm{NMR}\left(\mathrm{CDCl}_{3}\right) \delta: 8.26(1 \mathrm{H}, \mathrm{d}, J=1.5 \mathrm{~Hz}), 8.02$ 
$(1 \mathrm{H}, \mathrm{dd}, J=8.8,1.8 \mathrm{~Hz}), 7.44(1 \mathrm{H}, \mathrm{d}, J=8.5 \mathrm{~Hz}), 6.86(1 \mathrm{H}, \mathrm{s}), 3.93(3 \mathrm{H}, \mathrm{s}), 2.49(2 \mathrm{H}, \mathrm{t}$, $J=7.2 \mathrm{~Hz}), 1.71-1.24(8 \mathrm{H}, \mathrm{m}), 0.91(3 \mathrm{H}, \mathrm{t}, J=6.9 \mathrm{~Hz}) ;{ }^{13} \mathrm{C}$ NMR $(75 \mathrm{MHz}$, DMSO-d 6 ) $\delta 167.3,157.1,140.9,128.1,126.9,125.7,123.6,111.1,110.4,98.2,70.9,52.3,31.5$, 28.8, 28.3, 22.7, 19.8, 14.2; HRMS (EI) $\mathrm{m} / \mathrm{z}$ calcd. for: $[\mathrm{M}]^{+}$284.1416, $\mathrm{m} / \mathrm{z}$ found: 284.1412 .

\section{2-Oct-1-ynylnaphtho[2,1-b]furan (4k)}

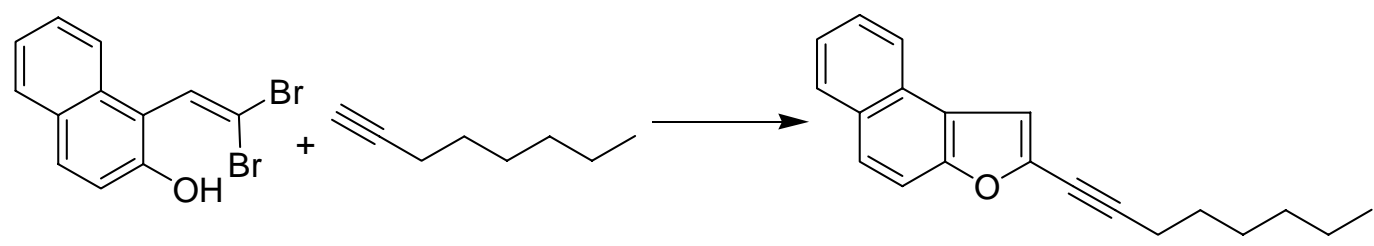

A carousel reaction tube $(24 \times 150 \mathrm{~mm})$ was charged with 1-(2,2-dibromovinyl)naphthalen-2-ol (135 mg, $0.41 \mathrm{mmol}), 10 \% \mathrm{Pd}-\mathrm{C}$ (4.4 mg, 0.0041 $\mathrm{mmol}, 1 \mathrm{~mol} \%), \mathrm{P}(p-\mathrm{MeOPh})_{3}(5.8 \mathrm{mg}, 0.016 \mathrm{mmol}, 4 \mathrm{~mol} \%)$, and $\mathrm{CuI}(1.7 \mathrm{mg}, 0.0082$ mmol, $2 \mathrm{~mol} \%$ ), and was evacuated and purged with argon three times. To this mixture were added toluene $\left(2 \mathrm{~mL}\right.$, degassed), $\mathrm{H}_{2} \mathrm{O}$ ( $1 \mathrm{~mL}$, degassed), $i \mathrm{Pr}_{2} \mathrm{NH}(145 \mu \mathrm{L}, 1.03$ mmol) and 1-octyne $(100 \mu \mathrm{L}, 0.66 \mathrm{mmol})$, and then heated to $100{ }^{\circ} \mathrm{C}$ with stirring for 12 h. The reaction mixture was then cooled to $\mathrm{rt}$ and $\mathrm{H}_{2} \mathrm{O}(10 \mathrm{~mL})$ added. The mixture was extracted with EtOAc $(2 \times 15 \mathrm{~mL})$, and combined extracts were washed with sat. $\mathrm{NH}_{4} \mathrm{Cl}$ and brine, then dried and solvent was removed in vacuo. The resulting crude material was purified by flash chromatography eluting with $0.8 \%$ EtOAc in hexane to afford $\mathbf{4 k}$ as a colorless oil $(112.0 \mathrm{mg}, 98 \%)$. IR $\left(\mathrm{CHCl}_{3}\right) \vee 3056,2930,2857,2233,1629,1556$, 1524, 1455, 1386, 1344, 1326, 1292, 1236, 1218, 1158, 1135, $1079 \mathrm{~cm}^{-1} ;{ }^{1} \mathrm{H}-\mathrm{NMR}$ $\left(\mathrm{CDCl}_{3}\right) \delta: 8.06(1 \mathrm{H}, \mathrm{d}, J=8.2 \mathrm{~Hz}), 7.90(1 \mathrm{H}, \mathrm{d}, J=8.2 \mathrm{~Hz}), 7.71(1 \mathrm{H}, \mathrm{d}, J=9.1 \mathrm{~Hz})$, 7.61-7.43 (3H, m), $7.30(1 \mathrm{H}, \mathrm{s}), 2.51(2 \mathrm{H}, \mathrm{t}, J=7.0 \mathrm{~Hz}), 1.72-1.23(8 \mathrm{H}, \mathrm{m}), 0.91(3 \mathrm{H}, \mathrm{t}$, $J=6.3 \mathrm{~Hz}) ;{ }^{13} \mathrm{C}$ NMR $\left(75 \mathrm{MHz}, \mathrm{DMSO}-d_{6}\right) \delta 152.3,138.9,130.6,128.9,127.5,126.7$, 126.3, 124.9, 123.6, 123.3, 112.3, 109.3, 97.3, 71.6, 31.5, 28.8, 28.5, 22.7, 19.9, 14.3; HRMS (EI) $\mathrm{m} / \mathrm{z}$ calcd. for: $[\mathrm{M}]^{+} 276.1505, \mathrm{~m} / \mathrm{z}$ found: 276.1514 .

\section{7-Methoxy-2-oct-1-ynylbenzofuran (4l)}<smiles>COc1cccc(C=C(Br)Br)c1O</smiles><smiles>C#CCCCCCC</smiles><smiles>CCCCCCC#Cc1cc2cccc(OC)c2o1</smiles>

A carousel reaction tube $(24 \times 150 \mathrm{~mm})$ was charged with 2-(2,2-dibromovinyl)-6-methoxyphenol (120 mg, $0.39 \mathrm{mmol}), 10 \% \mathrm{Pd}-\mathrm{C}$ (29.0 mg, $0.027 \mathrm{mmol}, 7 \mathrm{~mol} \%), \mathrm{P}(p-\mathrm{MeOPh})_{3}(13.7 \mathrm{mg}, 0.039 \mathrm{mmol}, 10 \mathrm{~mol} \%)$, and $\mathrm{CuI}(3.7$ 
$\mathrm{mg}, 0.020 \mathrm{mmol}, 5 \mathrm{~mol} \%$ ), and was evacuated and purged with argon three times. To this mixture were added toluene $\left(2 \mathrm{~mL}\right.$, degassed), $\mathrm{H}_{2} \mathrm{O}(1 \mathrm{~mL}$, degassed $),{ }^{2} \mathrm{Pr}_{2} \mathrm{NH}(164$ $\mu \mathrm{L}, 1.17 \mathrm{mmol})$ and 1 -octyne $(86 \mu \mathrm{L}, 0.58 \mathrm{mmol})$, and then heated to $100{ }^{\circ} \mathrm{C}$ with stirring for $64 \mathrm{~h}$. The reaction mixture was then cooled to $\mathrm{rt}$ and $\mathrm{H}_{2} \mathrm{O}(10 \mathrm{~mL})$ added. The mixture was extracted with EtOAc $(2 \times 15 \mathrm{~mL})$, and combined extracts were washed with sat. $\mathrm{NH}_{4} \mathrm{Cl}$ and brine, then dried and solvent was removed in vacuo. The resulting crude material was purified by flash chromatography eluting with $2 \%$ EtOAc in hexane to afford $\mathbf{4 l}$ as a pale yellow oil $(80.0 \mathrm{mg}, 80 \%)$. IR $\left(\mathrm{CHCl}_{3}\right) \vee 2934,2857$, 2234, 1621, 1615, 1593, 1494, 1489, 1455, 1435, 1359, 1318, 1270, 1210, 1183, 1159, 1098, $1061 \mathrm{~cm}^{-1}$; ${ }^{1} \mathrm{H}-\mathrm{NMR}\left(\mathrm{CDCl}_{3}\right) \delta: 7.17-7.08(2 \mathrm{H}, \mathrm{m}), 6.84-6.74(2 \mathrm{H}, \mathrm{m}), 4.00(3 \mathrm{H}$, s), $2.46(2 \mathrm{H}, \mathrm{t}, J=7.0 \mathrm{~Hz}), 1.68-1.23(8 \mathrm{H}, \mathrm{m}), 0.90(3 \mathrm{H}, \mathrm{t}, J=6.9 \mathrm{~Hz}) .{ }^{13} \mathrm{C} \mathrm{NMR}(75$ MHz, DMSO-d 6 ) $\delta 145.3,144.0,139.7,129.6,123.9,113.4,110.3,107.3,97.1,71.2$, 56.3, 31.5, 28.8, 28.4, 22.7, 19.7, 14.2; HRMS (EI) $\mathrm{m} / \mathrm{z}$ calcd. for: $[\mathrm{M}]^{+} 256.1468, \mathrm{~m} / \mathrm{z}$ found: 256.1463 .

\section{3-Methyl-2-oct-1-ynyl-benzofuran (4m)}<smiles>CC(=C(Br)Br)c1ccccc1O</smiles><smiles>C#CCCCCCC</smiles>

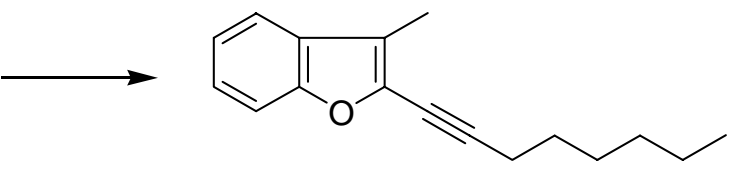

A carousel reaction tube $(24 \times 150 \mathrm{~mm})$ was charged with 2-(2,2-Dibromo-1-methylvinyl)phenol (145 mg, $0.50 \mathrm{mmol}), 10 \% \mathrm{Pd}-\mathrm{C}$ (10.6 mg, $0.010 \mathrm{mmol}, 2 \mathrm{~mol} \%), \mathrm{P}(\mathrm{p}-\mathrm{MeOPh})_{3}(13.9 \mathrm{mg}, 0.040 \mathrm{mmol}, 8 \mathrm{~mol} \%)$, and $\mathrm{CuI}(4.0 \mathrm{mg}$, $0.022 \mathrm{mmol}, 4 \mathrm{~mol} \%$ ), and was evacuated and purged with argon three times. To this mixture were added toluene $\left(2 \mathrm{~mL}\right.$, degassed), $\mathrm{H}_{2} \mathrm{O}(1 \mathrm{~mL}$, degassed $), \operatorname{Pr}_{2} \mathrm{NH}(210 \mu \mathrm{L}$, $1.49 \mathrm{mmol})$ and 1-octyne $(100 \mu \mathrm{L}, 0.66 \mathrm{mmol})$, and then heated to $100{ }^{\circ} \mathrm{C}$ with stirring for $12 \mathrm{~h}$. The reaction mixture was then cooled to $\mathrm{rt}$ and $\mathrm{H}_{2} \mathrm{O}(10 \mathrm{~mL})$ added. The mixture was extracted with EtOAc $(2 \times 15 \mathrm{~mL})$, and combined extracts were washed with sat. $\mathrm{NH}_{4} \mathrm{Cl}$ and brine, then dried and solvent was removed in vacuo. The resulting crude material was purified by flash chromatography eluting with $0.5 \% \rightarrow 1.0 \%$ EtOAc in hexane to afford $\mathbf{4 m}$ as a colorless oil $(98.4 \mathrm{mg}, 82 \%)$. IR $\left(\mathrm{CHCl}_{3}\right) \vee 2927,2857$, 2228, 1995, 1586, 1451, 1360, 1348, 1256, 1197, 1115, $1094 \mathrm{~cm}^{-1} ;{ }^{1} \mathrm{H}-\mathrm{NMR}\left(\mathrm{CDCl}_{3}\right) \delta$ : 7.48-7.43 (1H, m), 7.40-7.35 (1H, m), $7.29(1 \mathrm{H}, \mathrm{dt}, J=7.3,1.5 \mathrm{~Hz}), 7.21(1 \mathrm{H}, \mathrm{dt}, J=$ $7.3,1.2 \mathrm{~Hz}), 2.52(2 \mathrm{H}, \mathrm{t}, J=7.2 \mathrm{~Hz}), 2.28(3 \mathrm{H}, \mathrm{s}), 1.72-1.59(2 \mathrm{H}, \mathrm{m}), 1.55-1.21(6 \mathrm{H}, \mathrm{m})$, $0.91(3 \mathrm{H}, \mathrm{t}, J=6.9 \mathrm{~Hz}) ;{ }^{13} \mathrm{C}$ NMR $\left(75 \mathrm{MHz}, \mathrm{DMSO}-d_{6}\right) \delta 154.2,136.6,129.2,125.2$, 122.7, 119.6 (2C), 111.2, 99.4, 70.8, 31.5, 28.8, 28.6, 22.7, 19.9, 14.2, 8.9; HRMS (EI) $\mathrm{m} / \mathrm{z}$ calcd. for: $[\mathrm{M}]^{+} 240.1514, \mathrm{~m} / \mathrm{z}$ found: 240.1508 . 


\section{Spectra}

\section{Indoles}
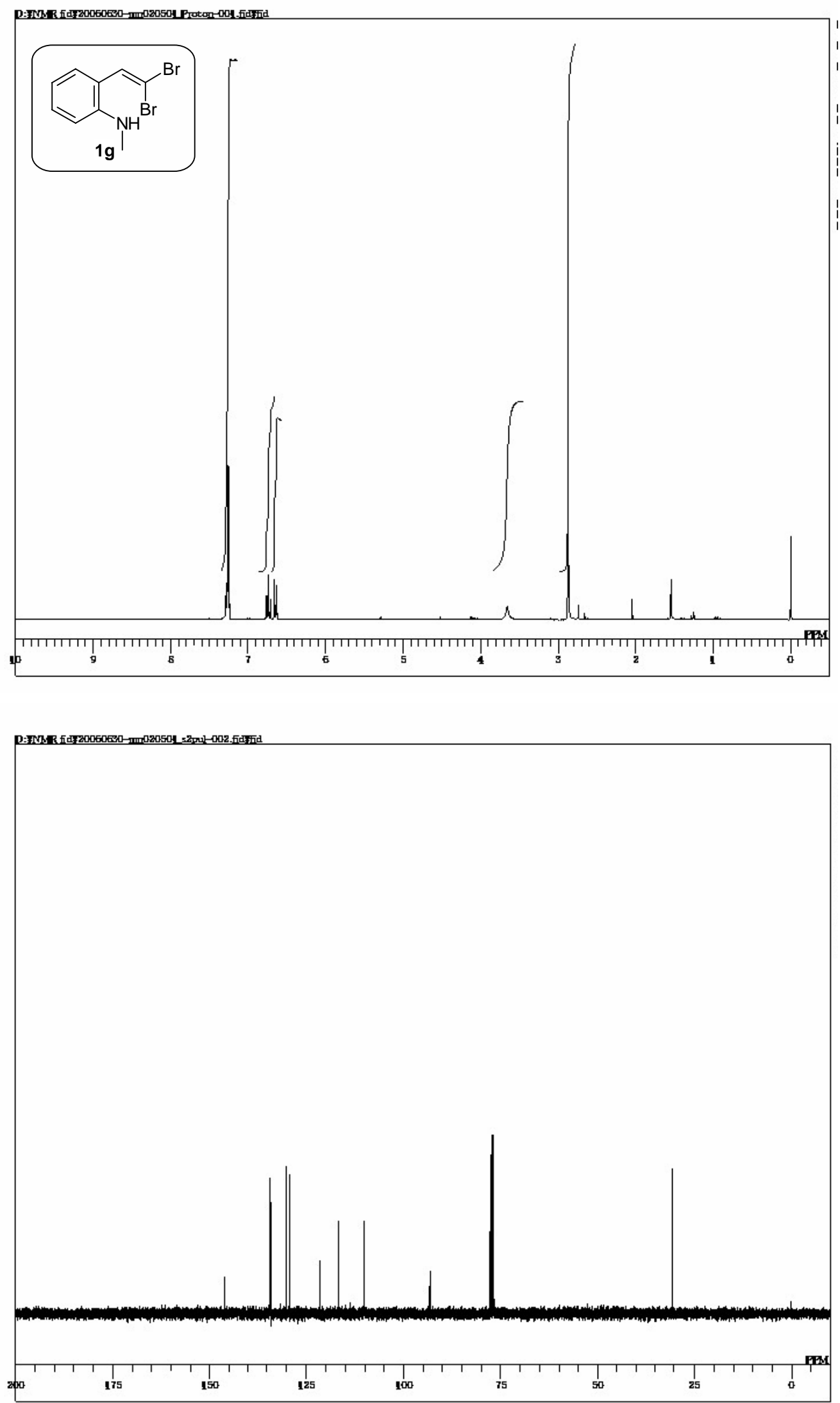

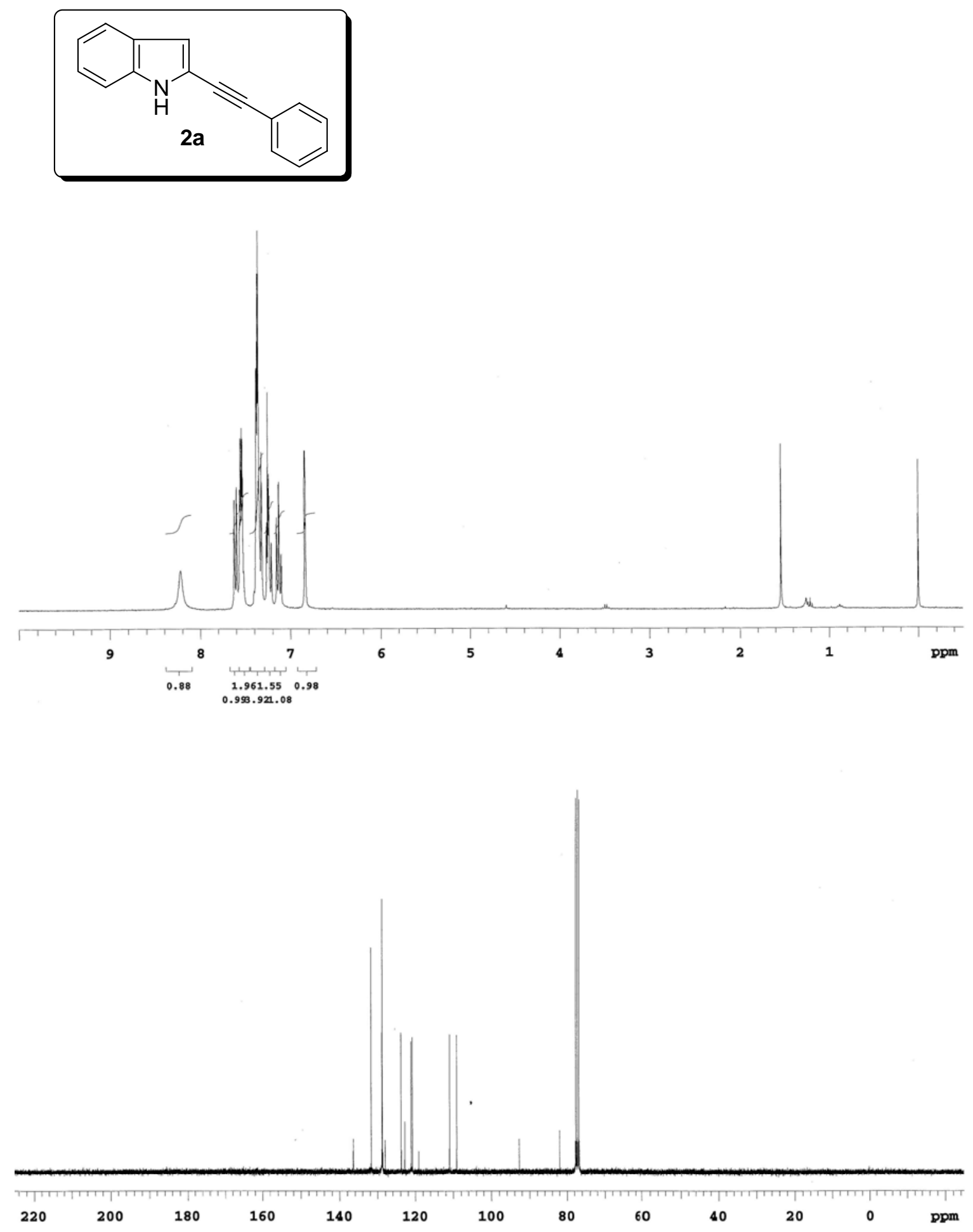

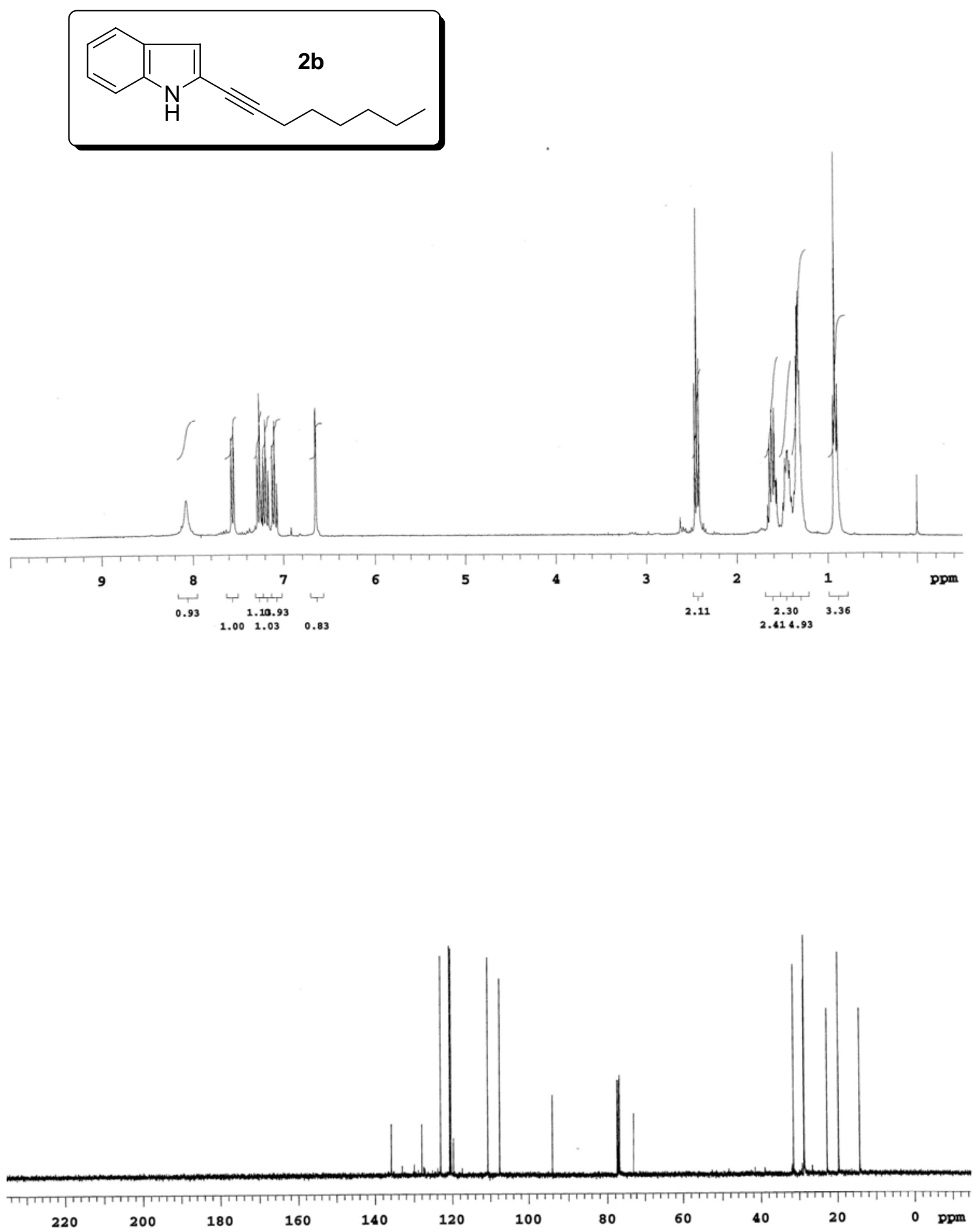

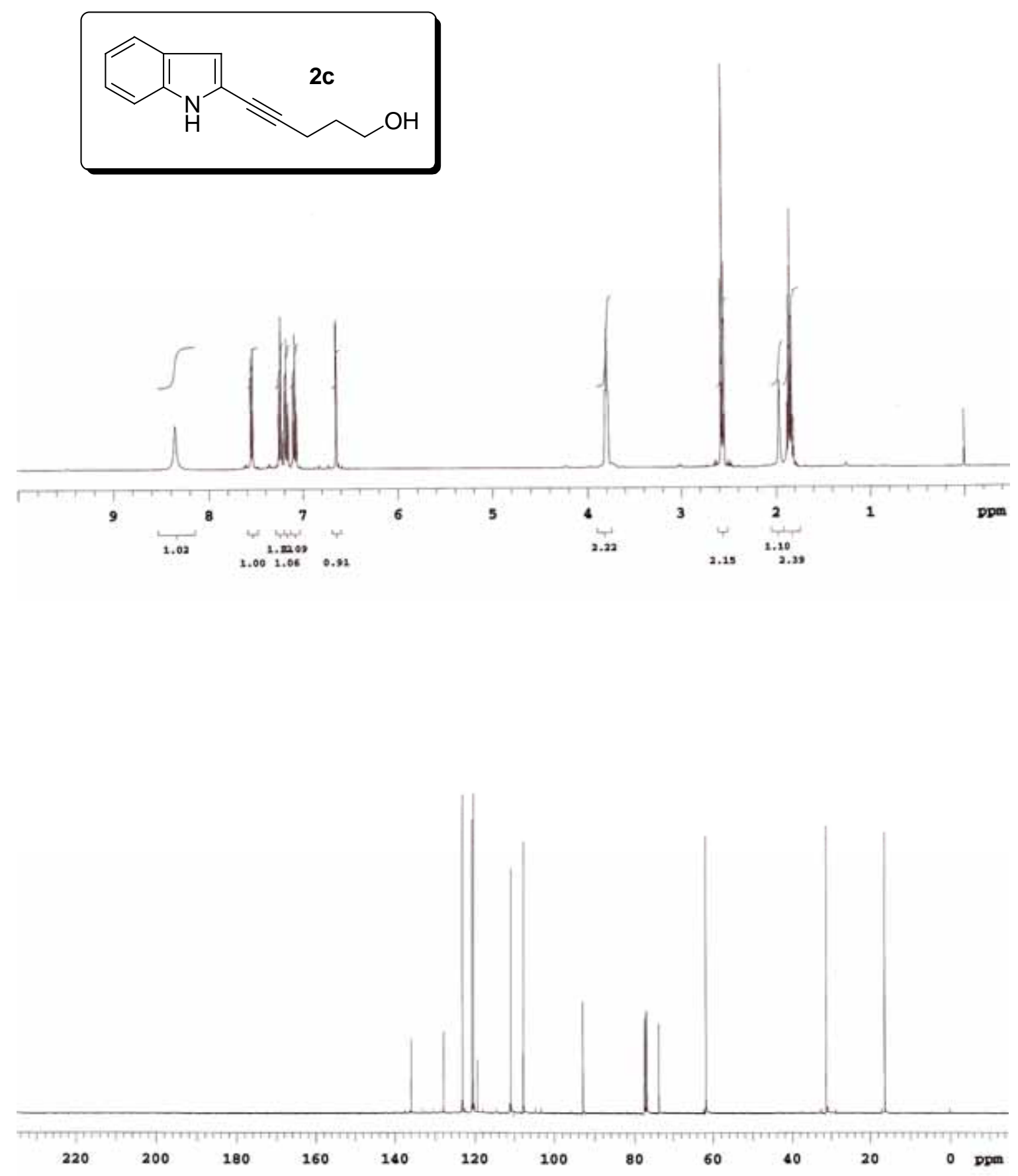

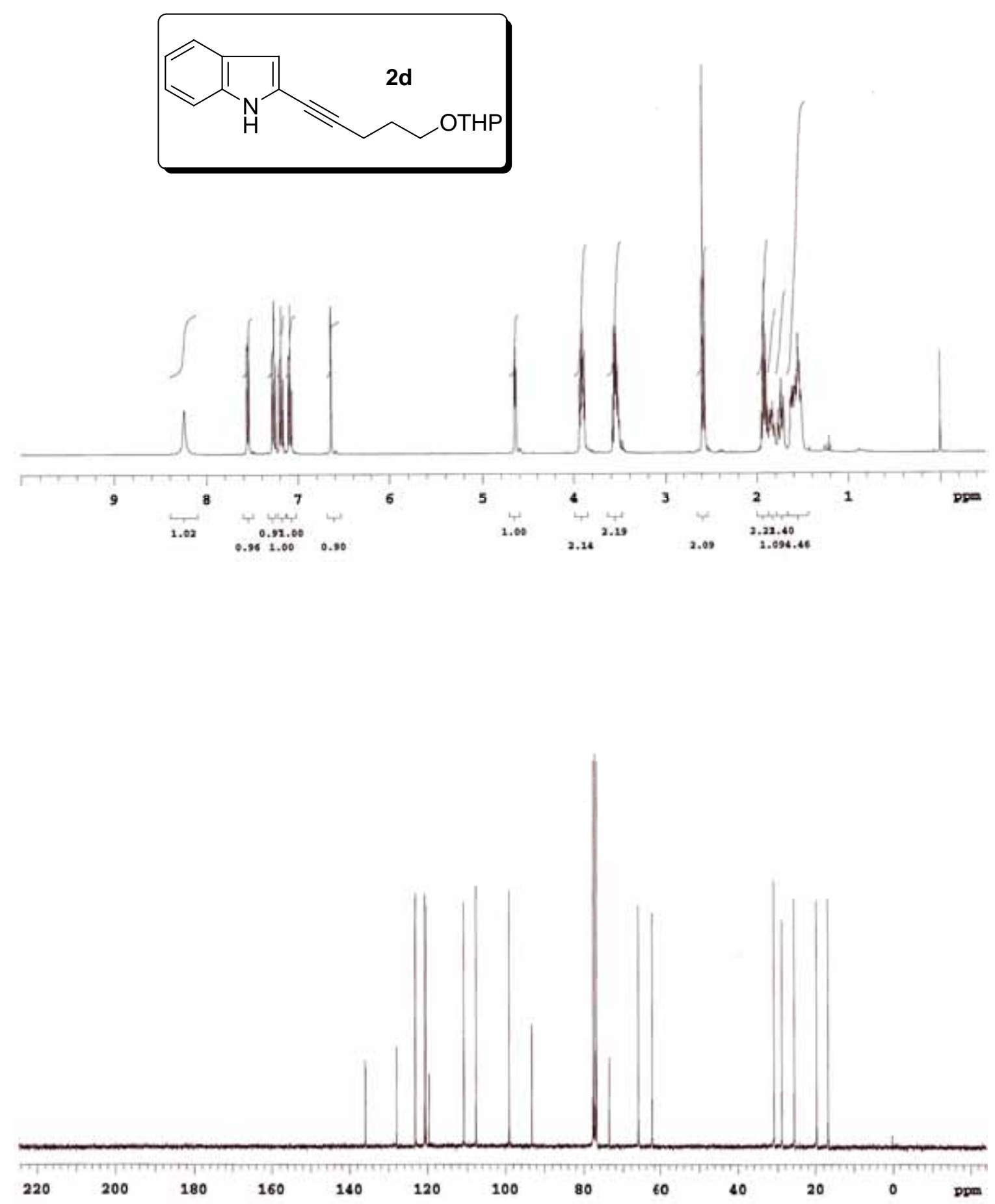

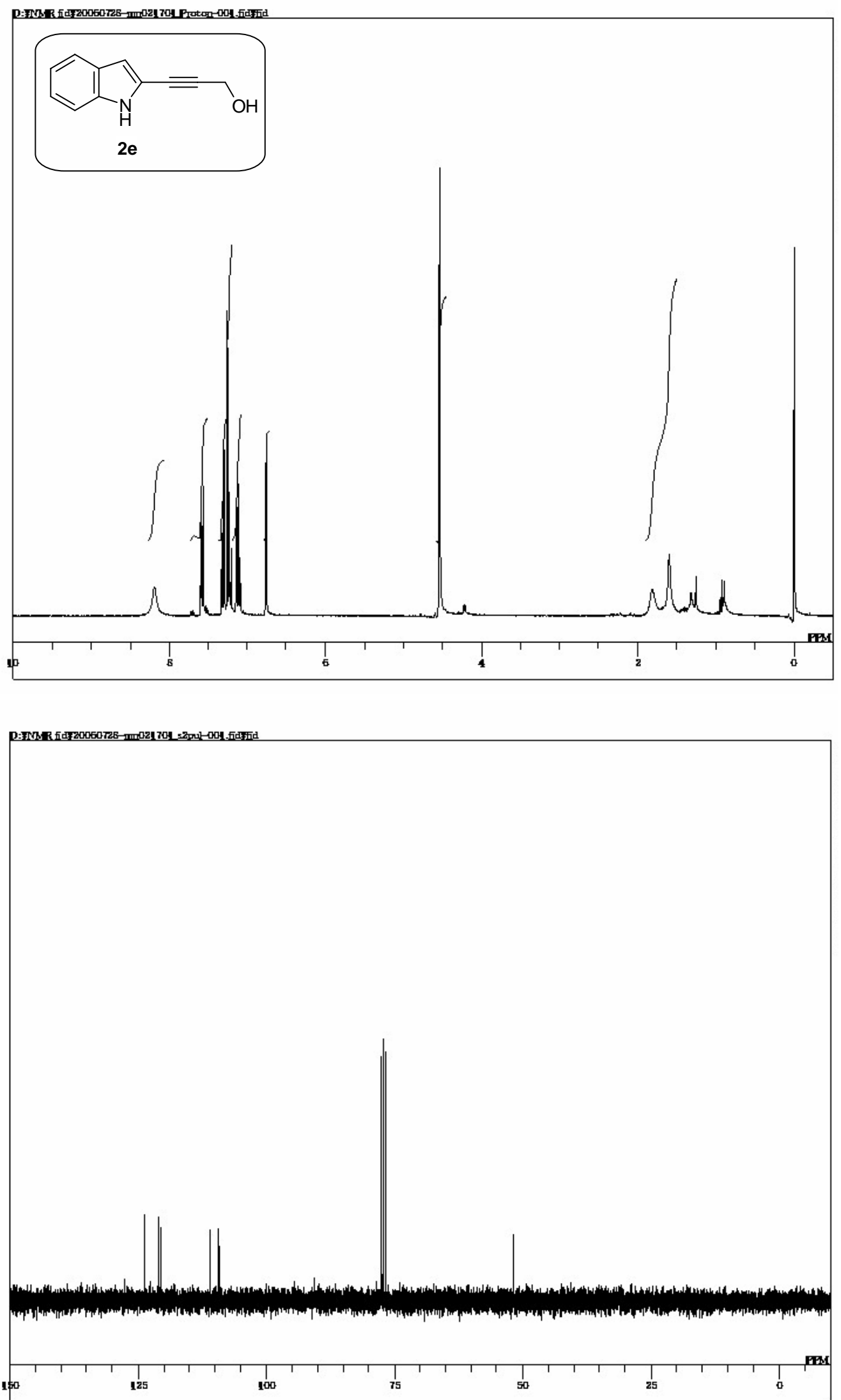

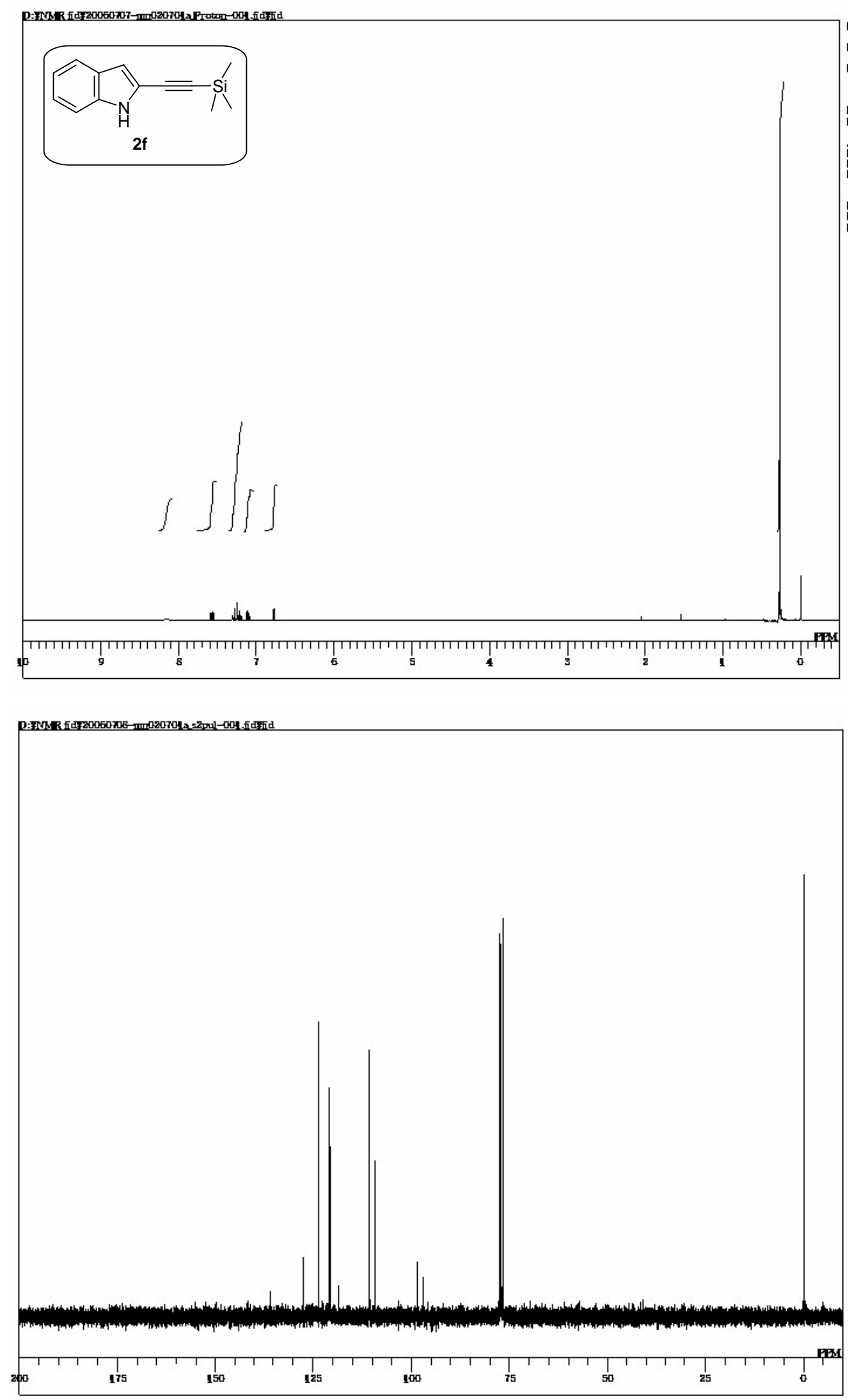

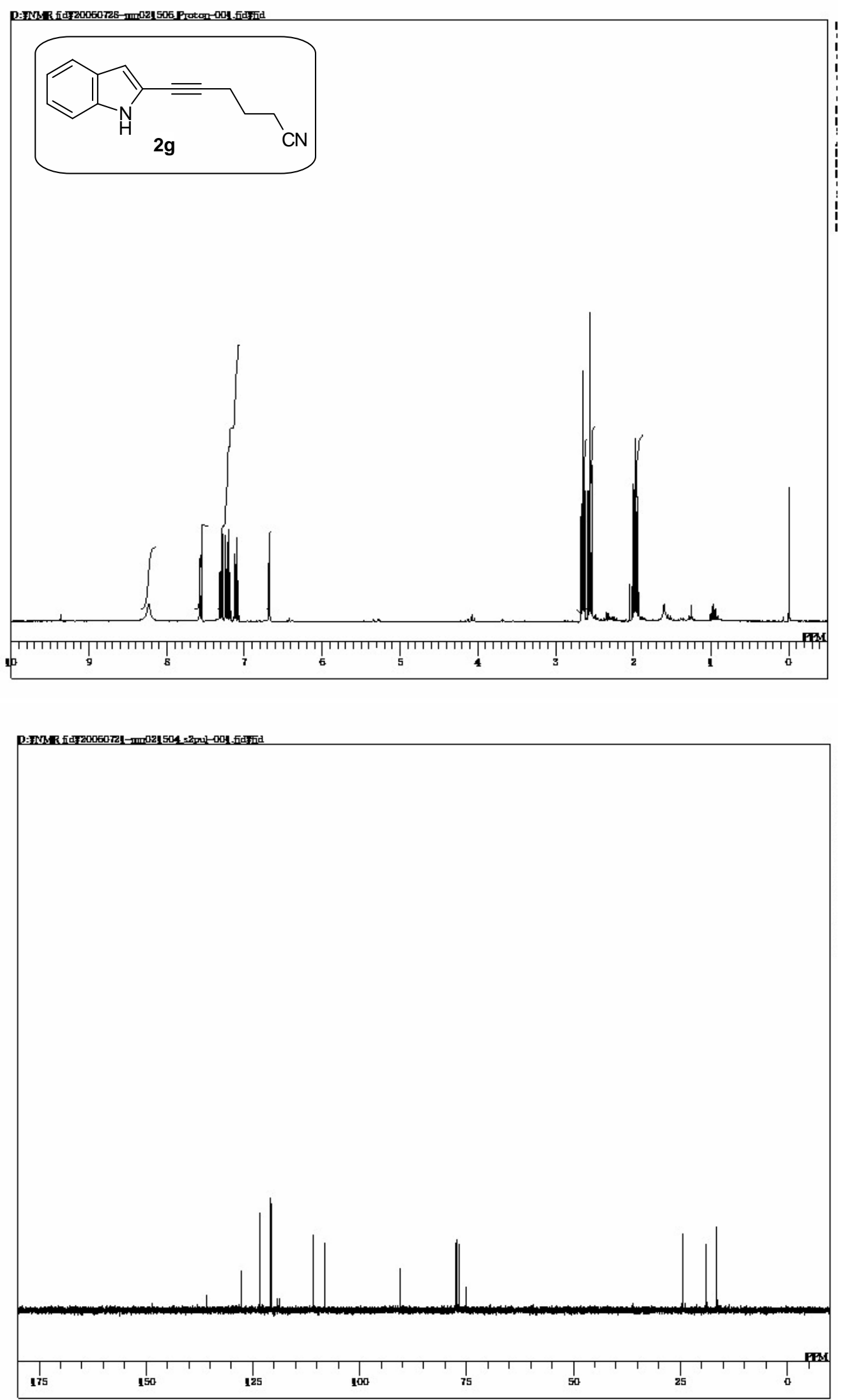

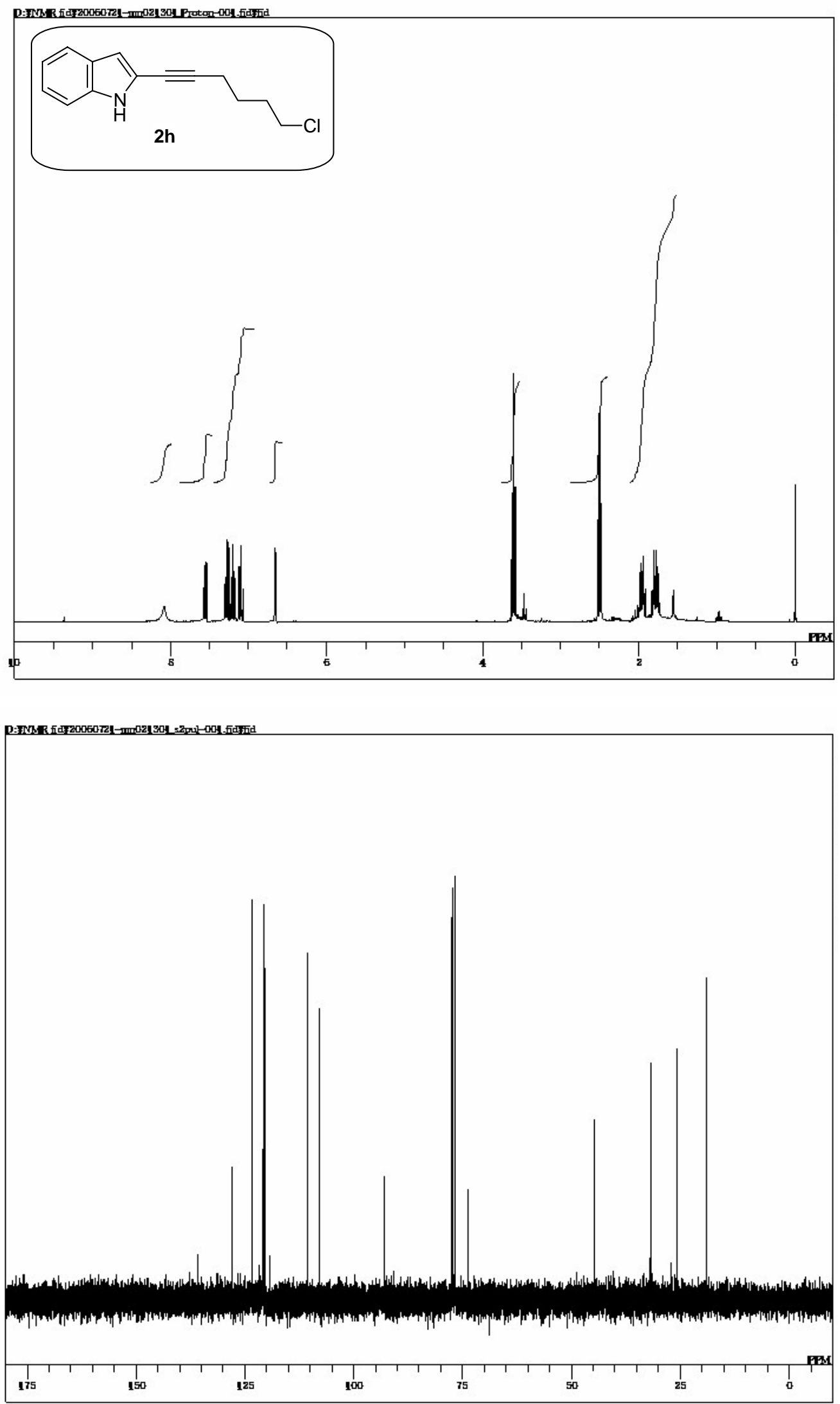

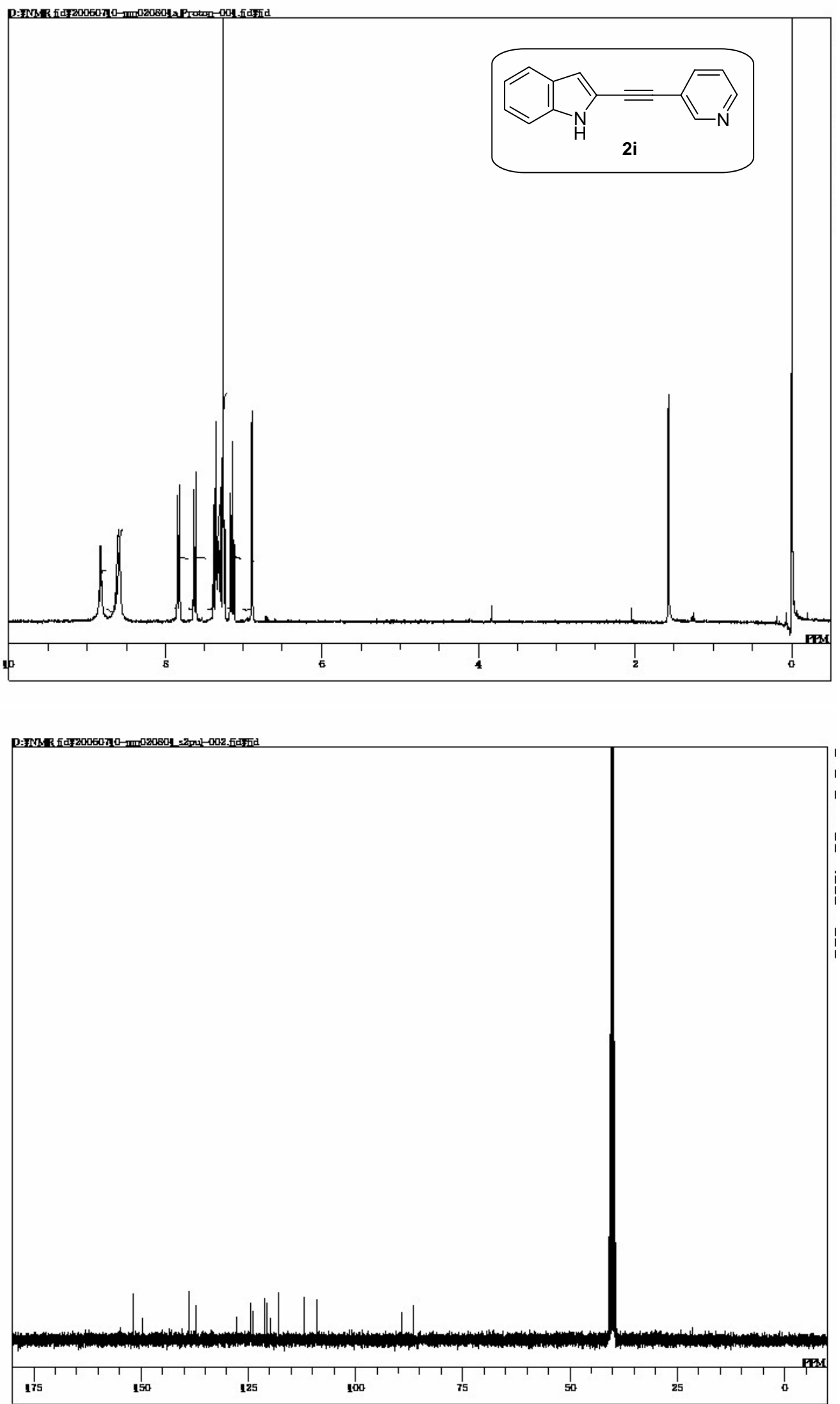

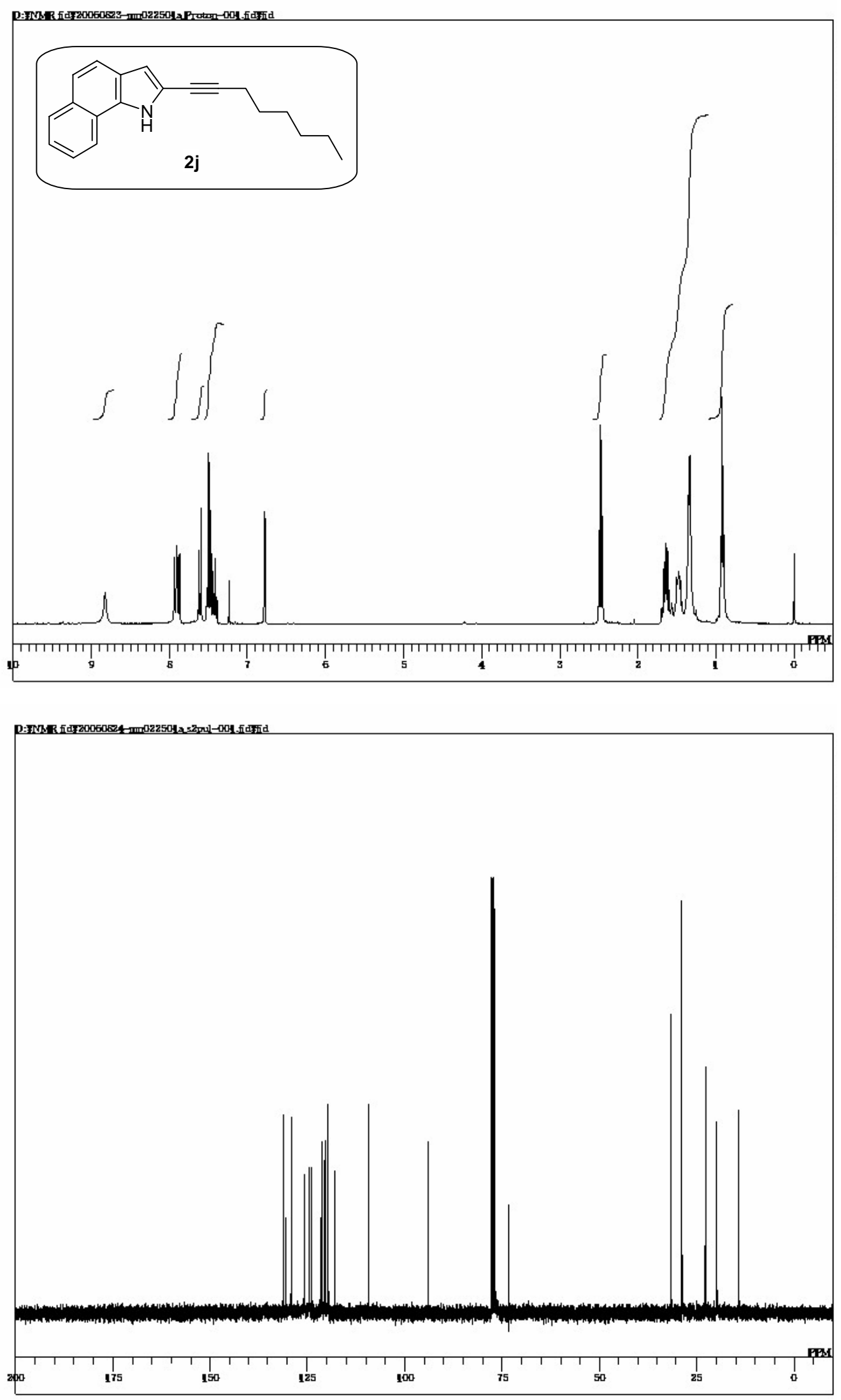

S36 

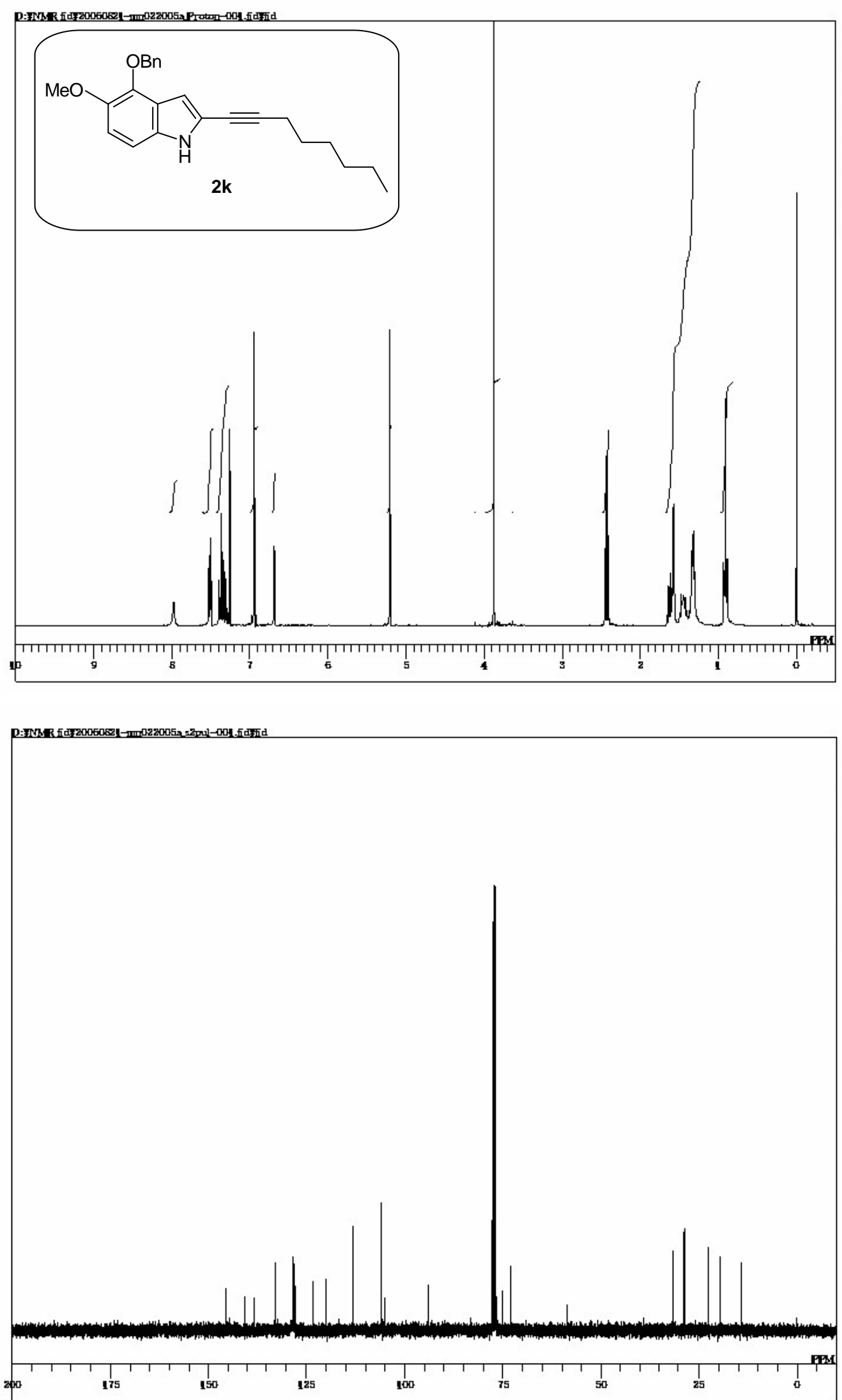

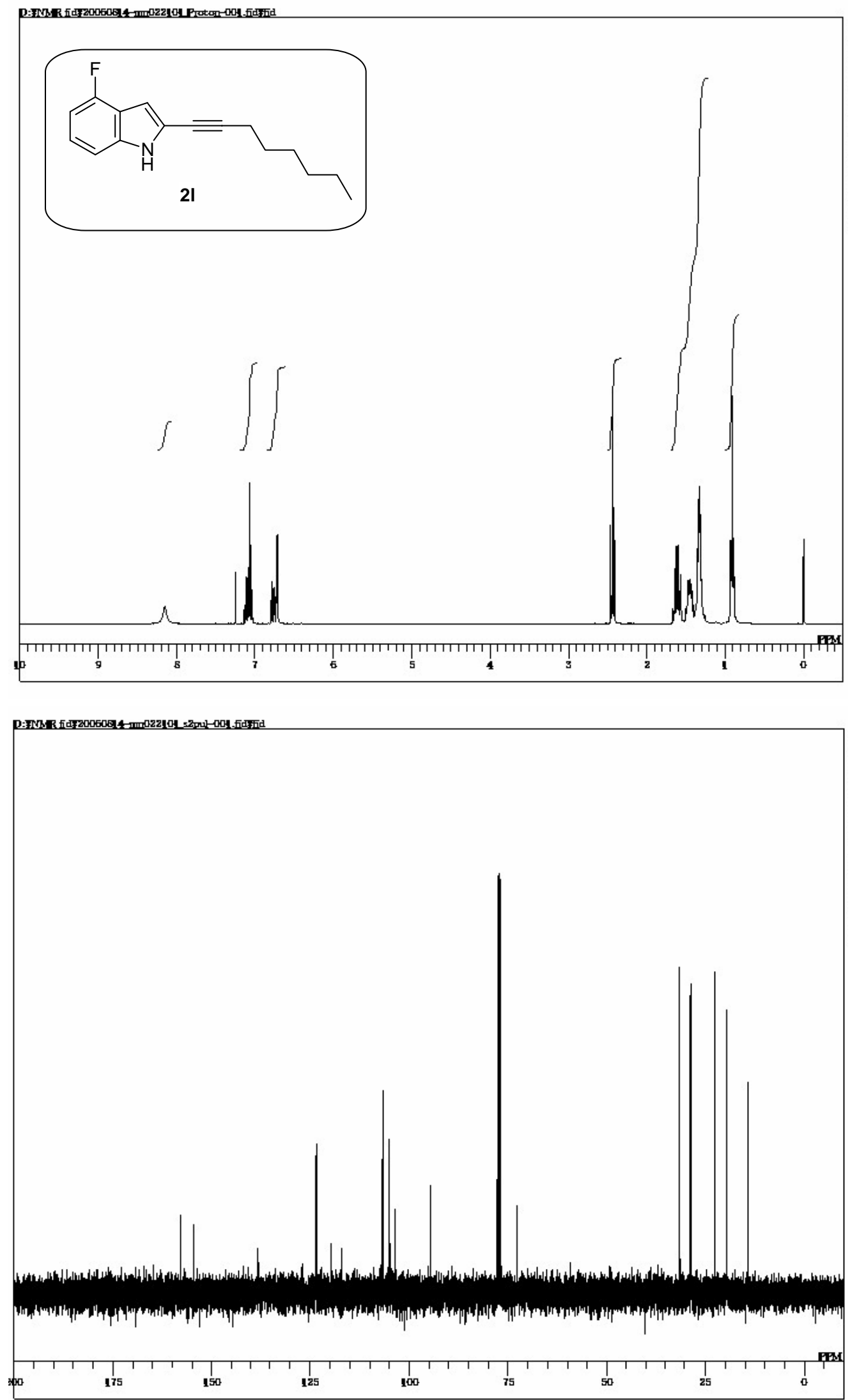

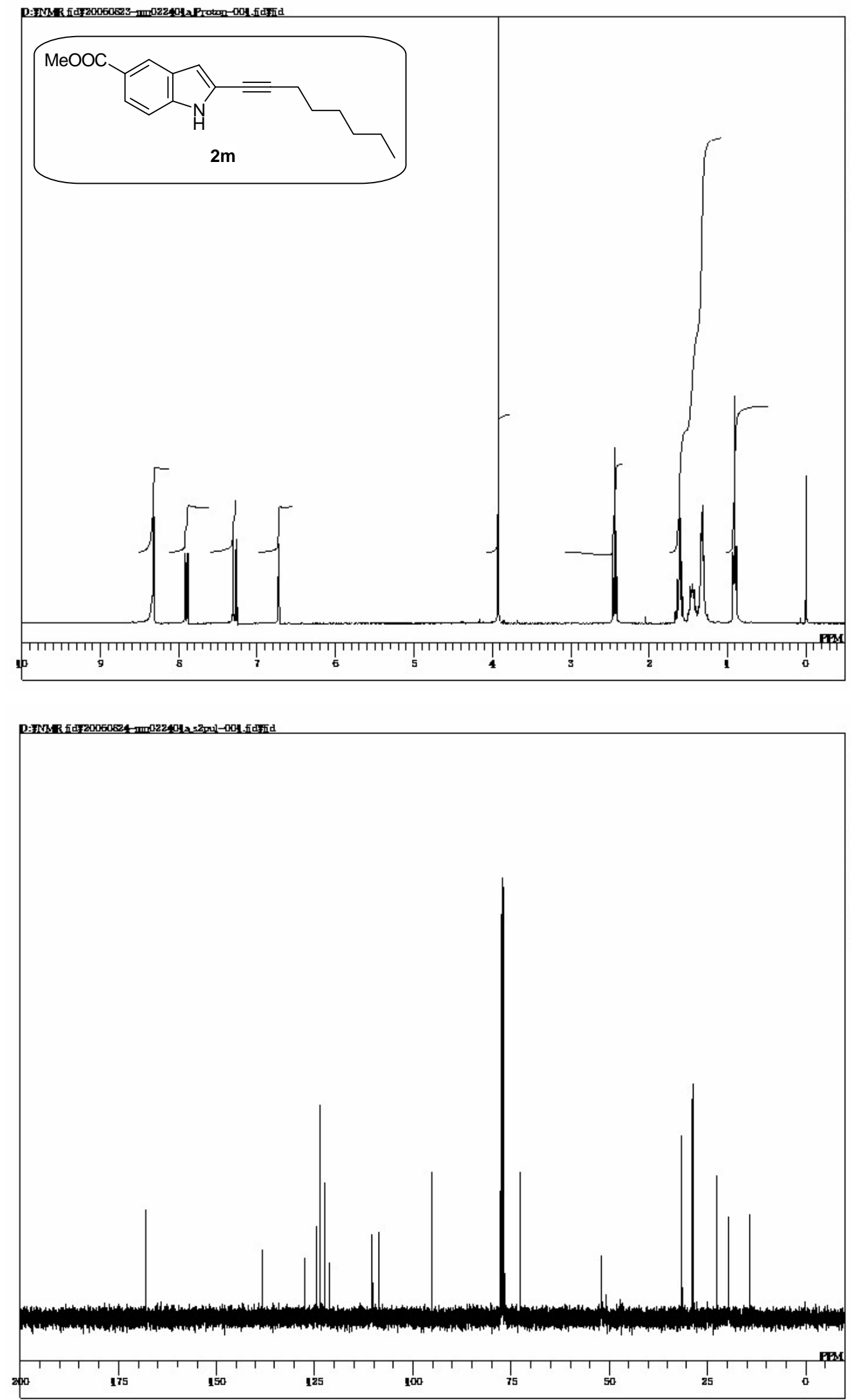

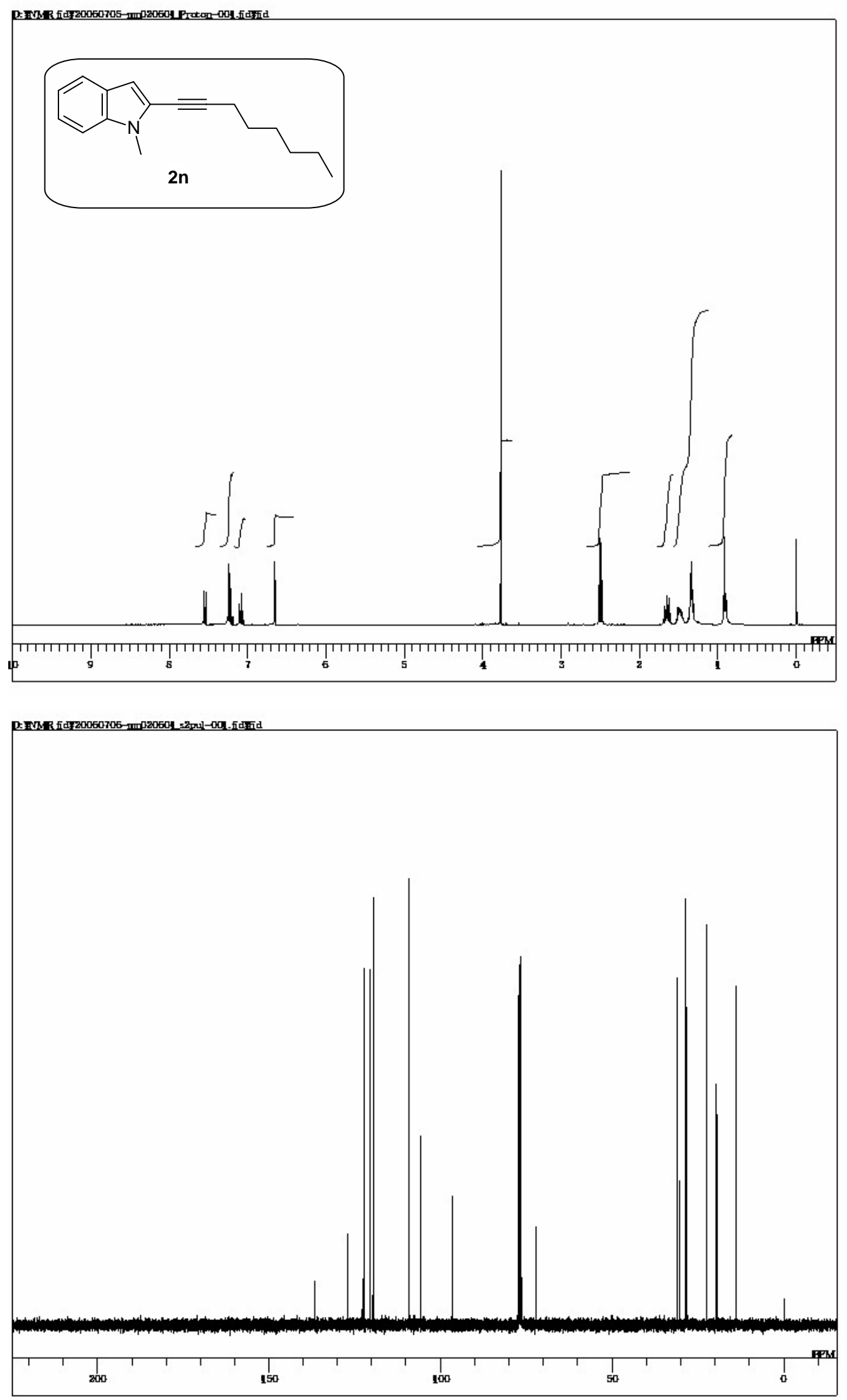

$\mathrm{S} 40$ 

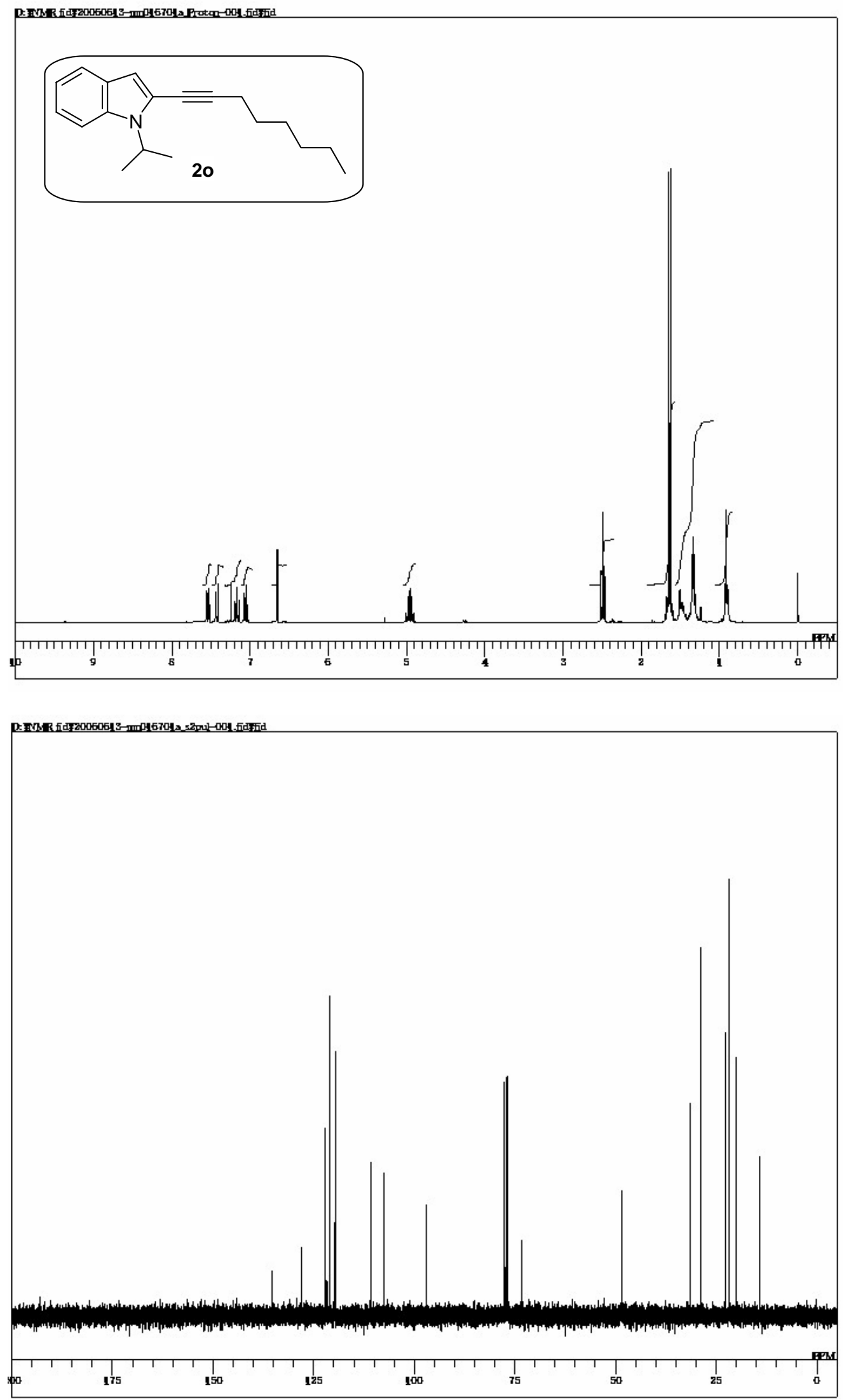

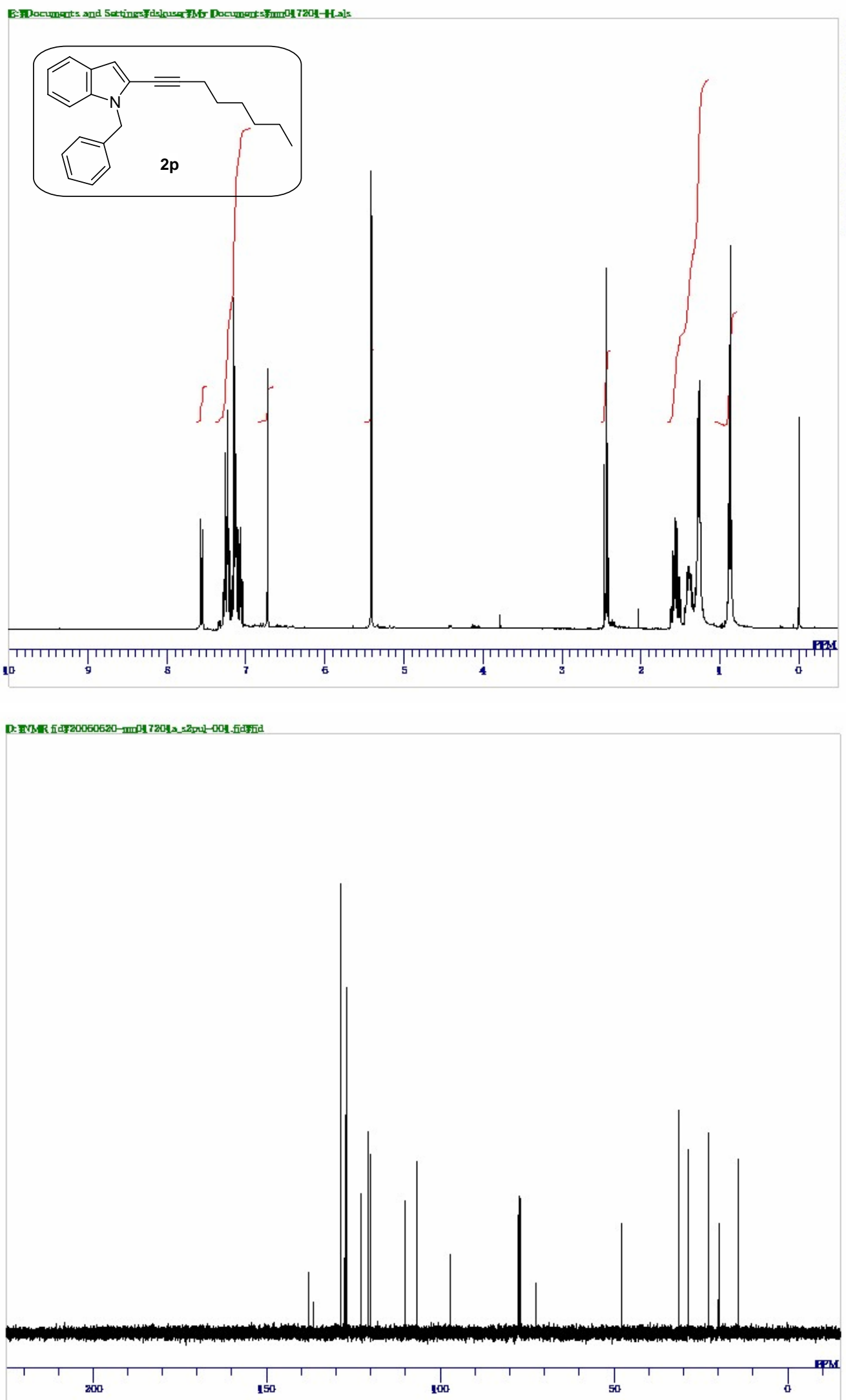

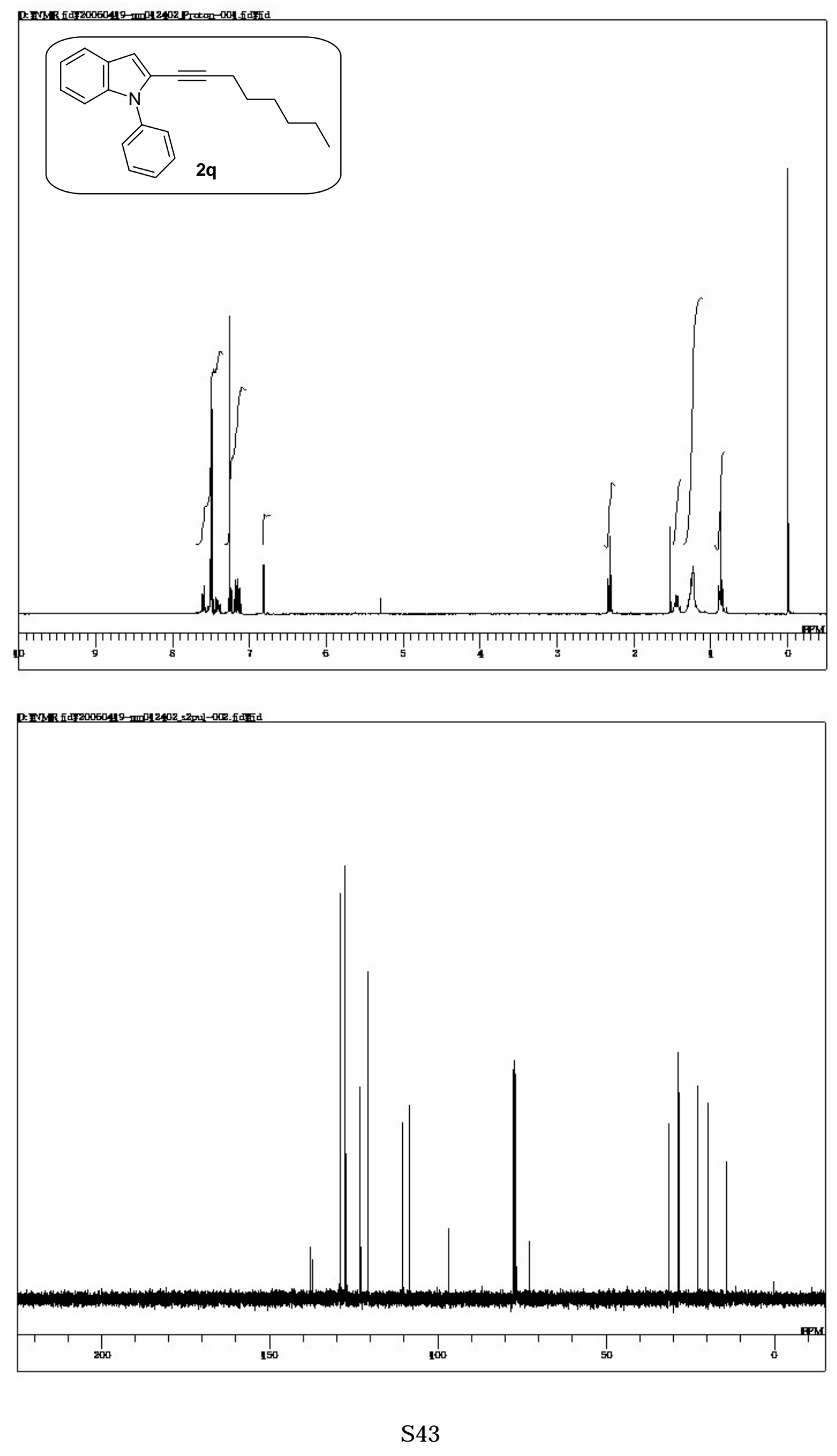


\section{Benzofurans}
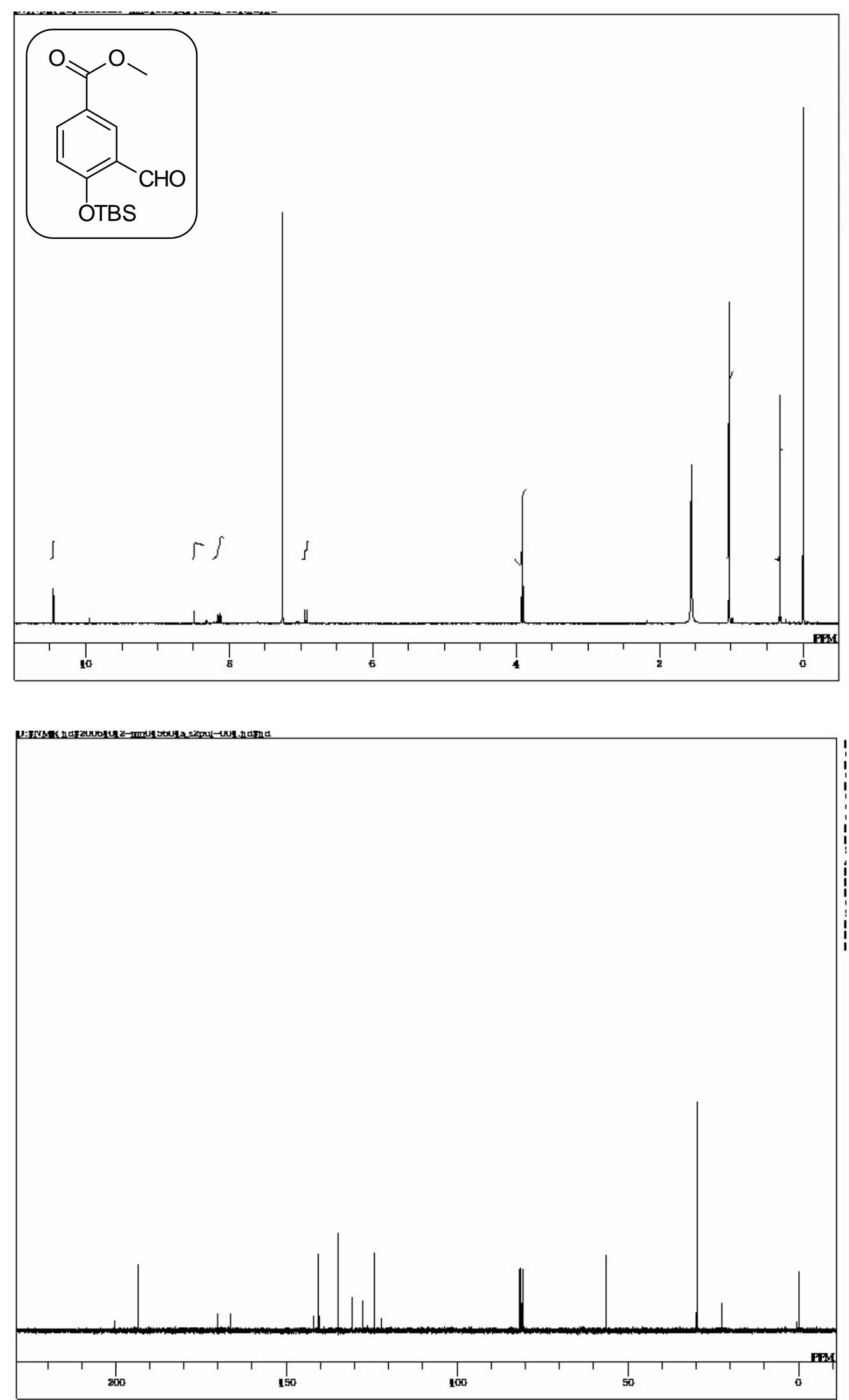

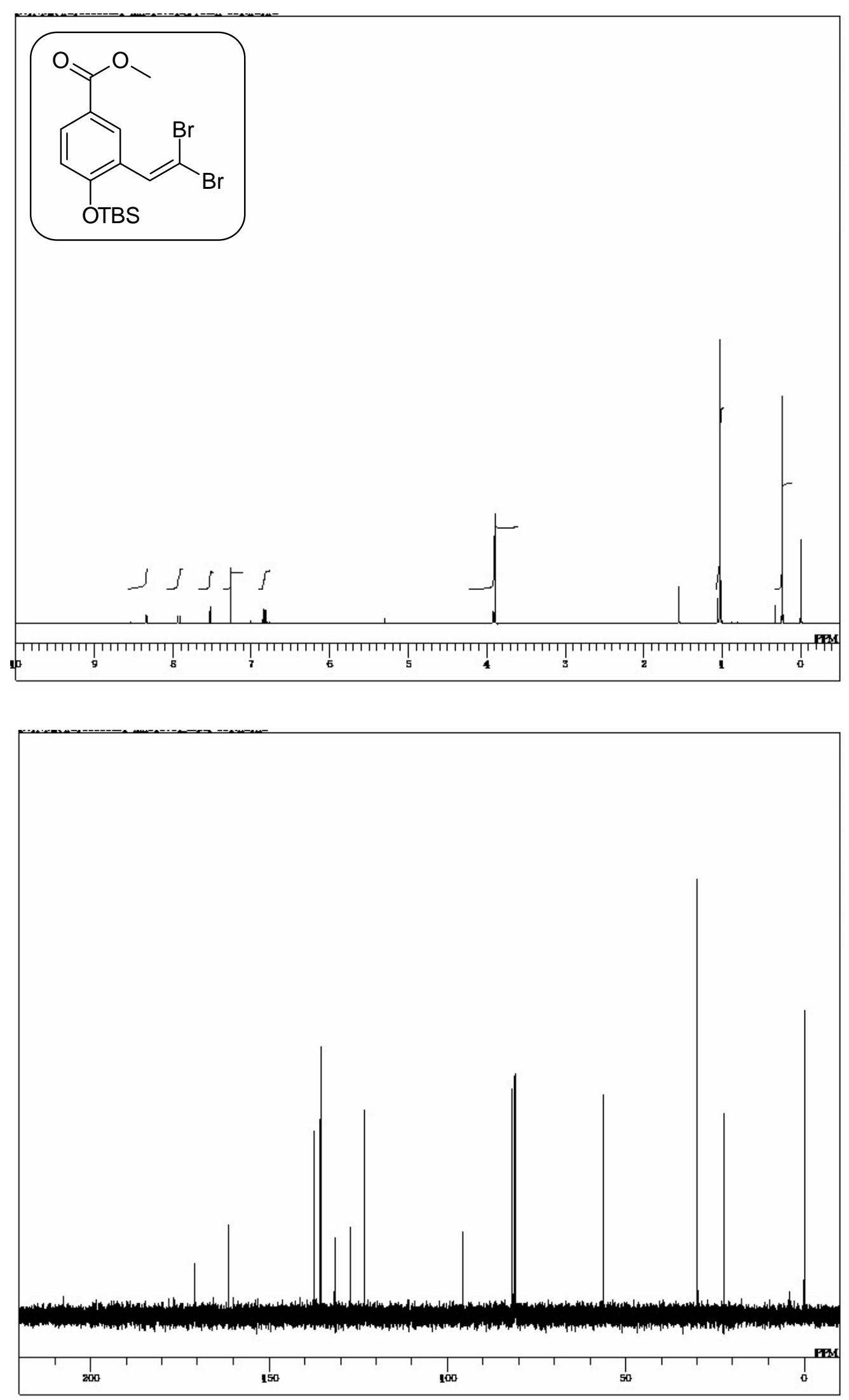

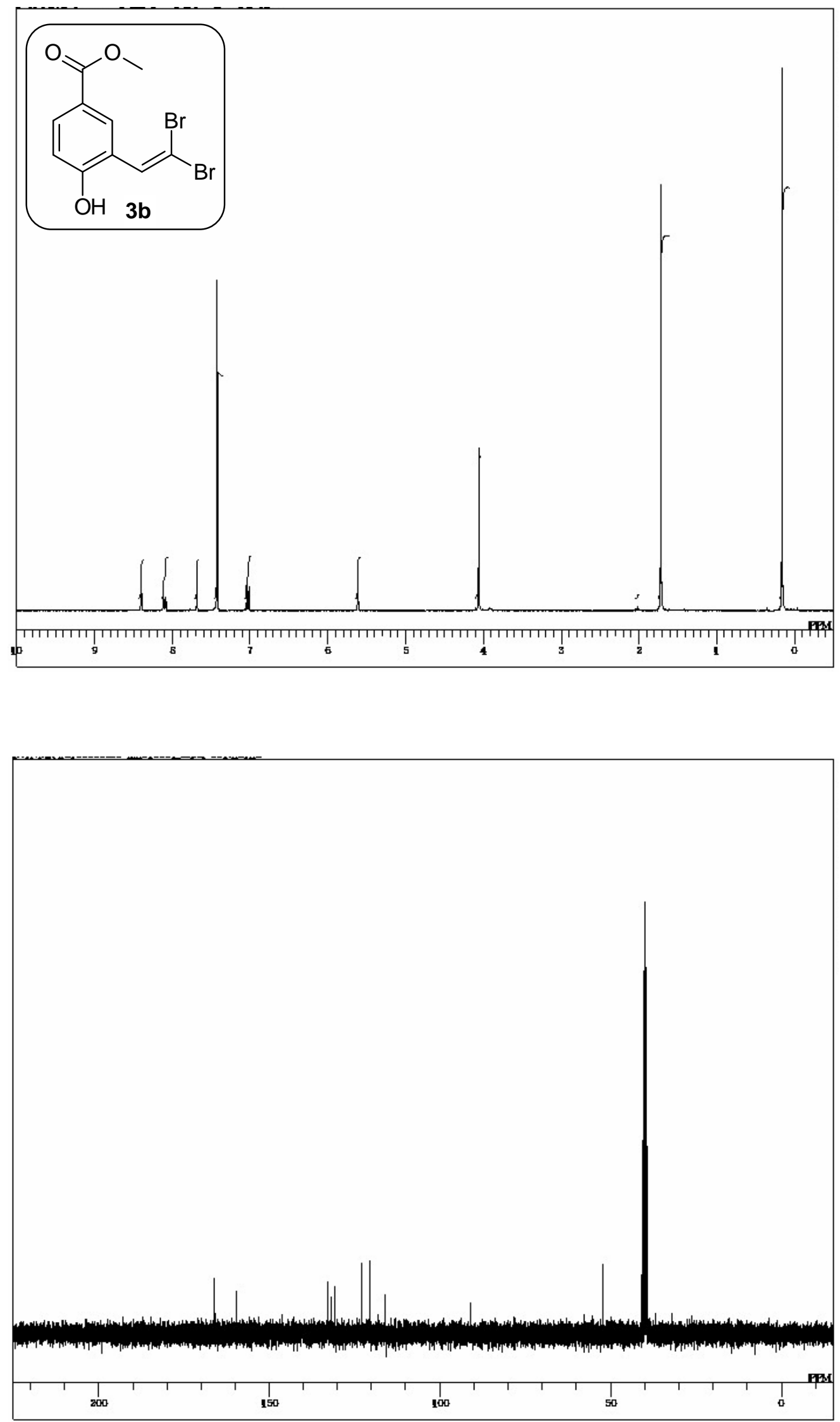

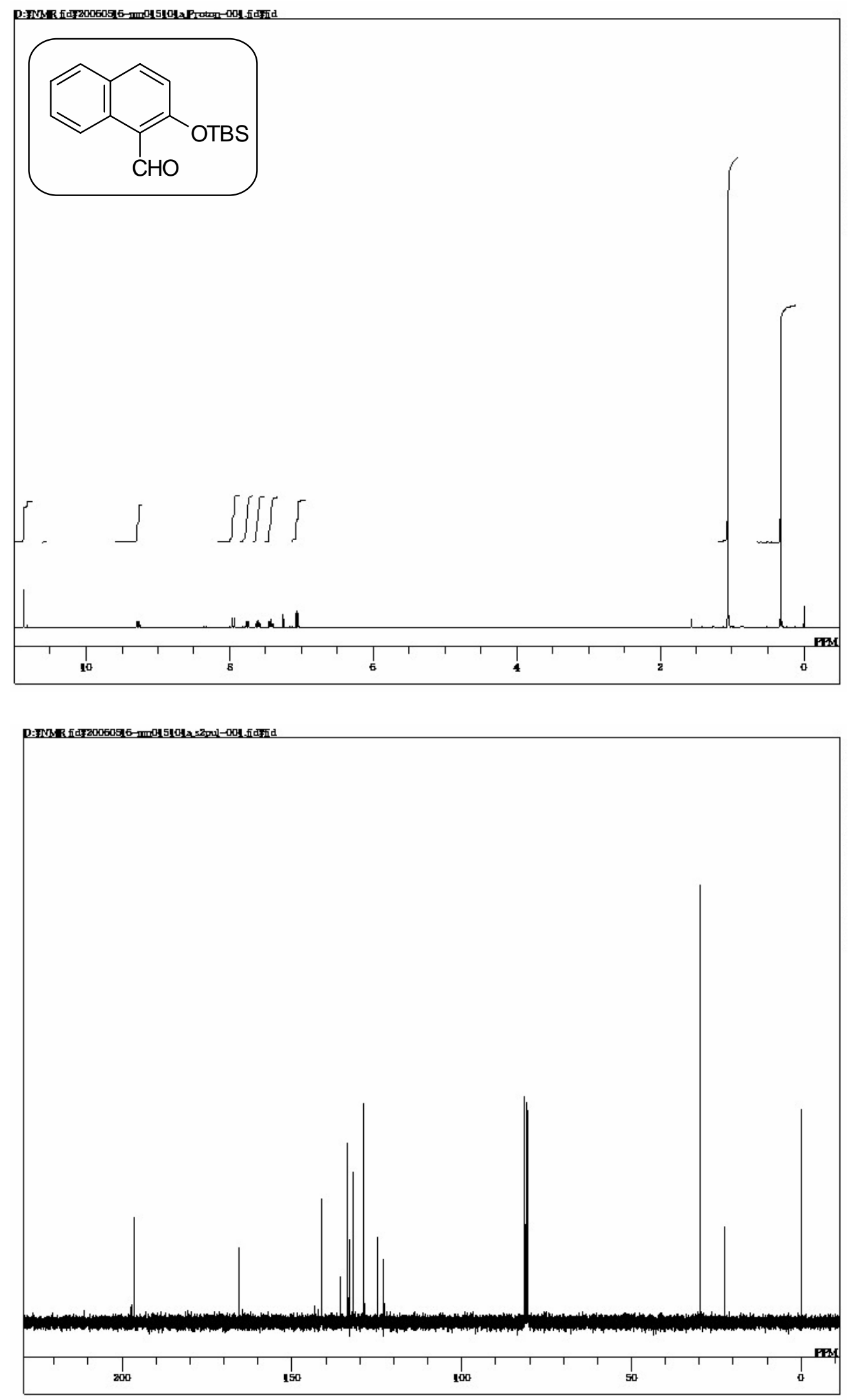

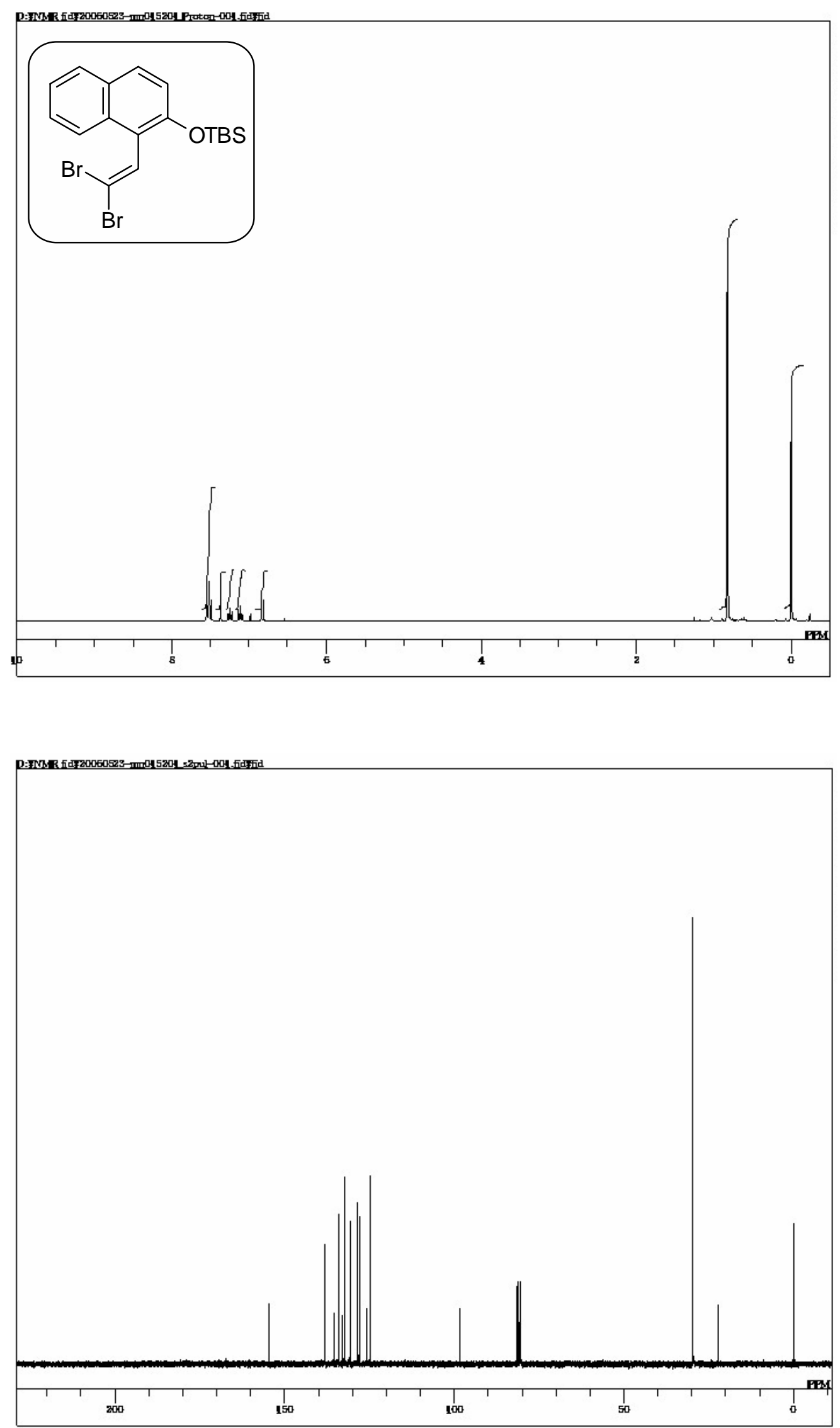

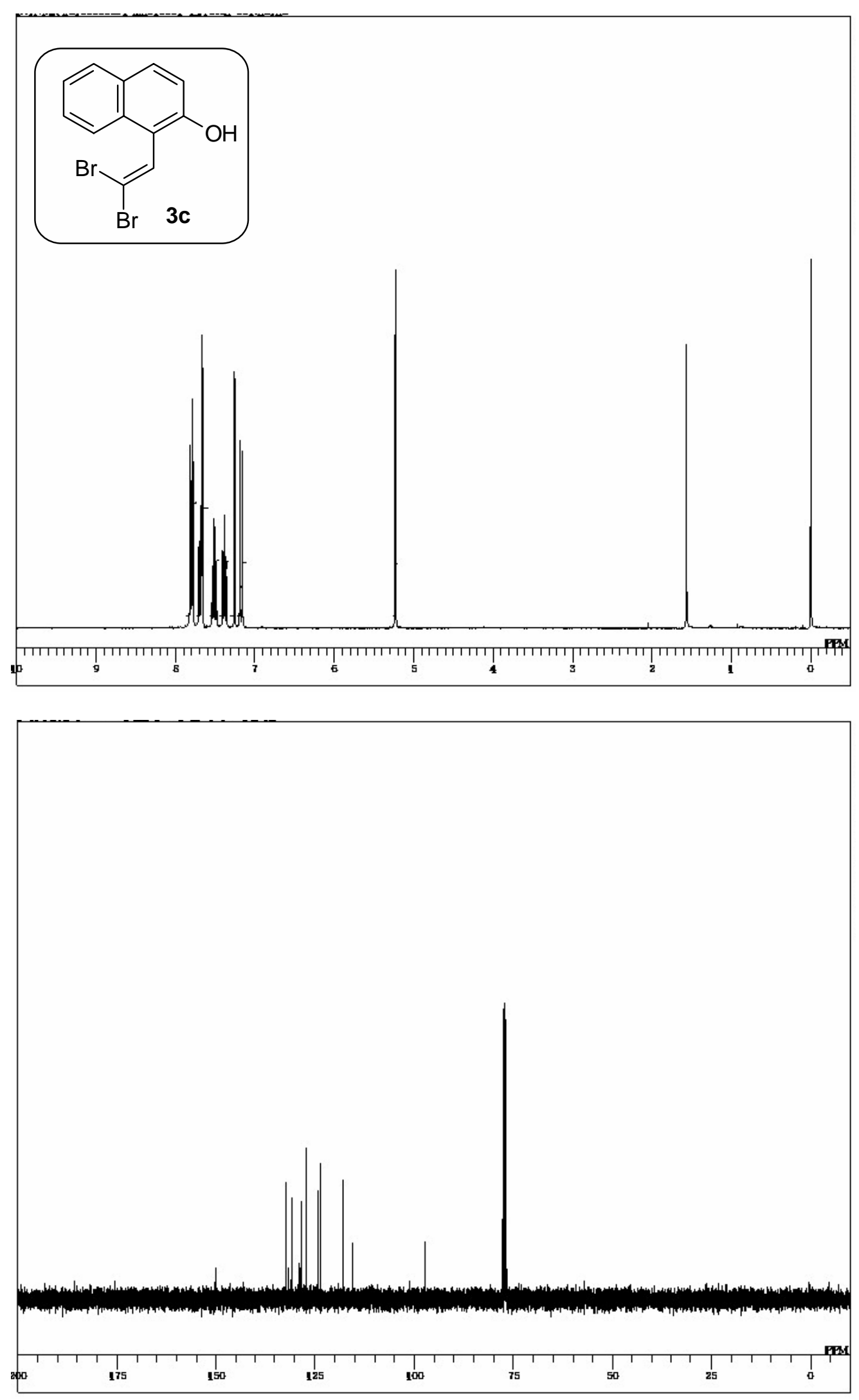

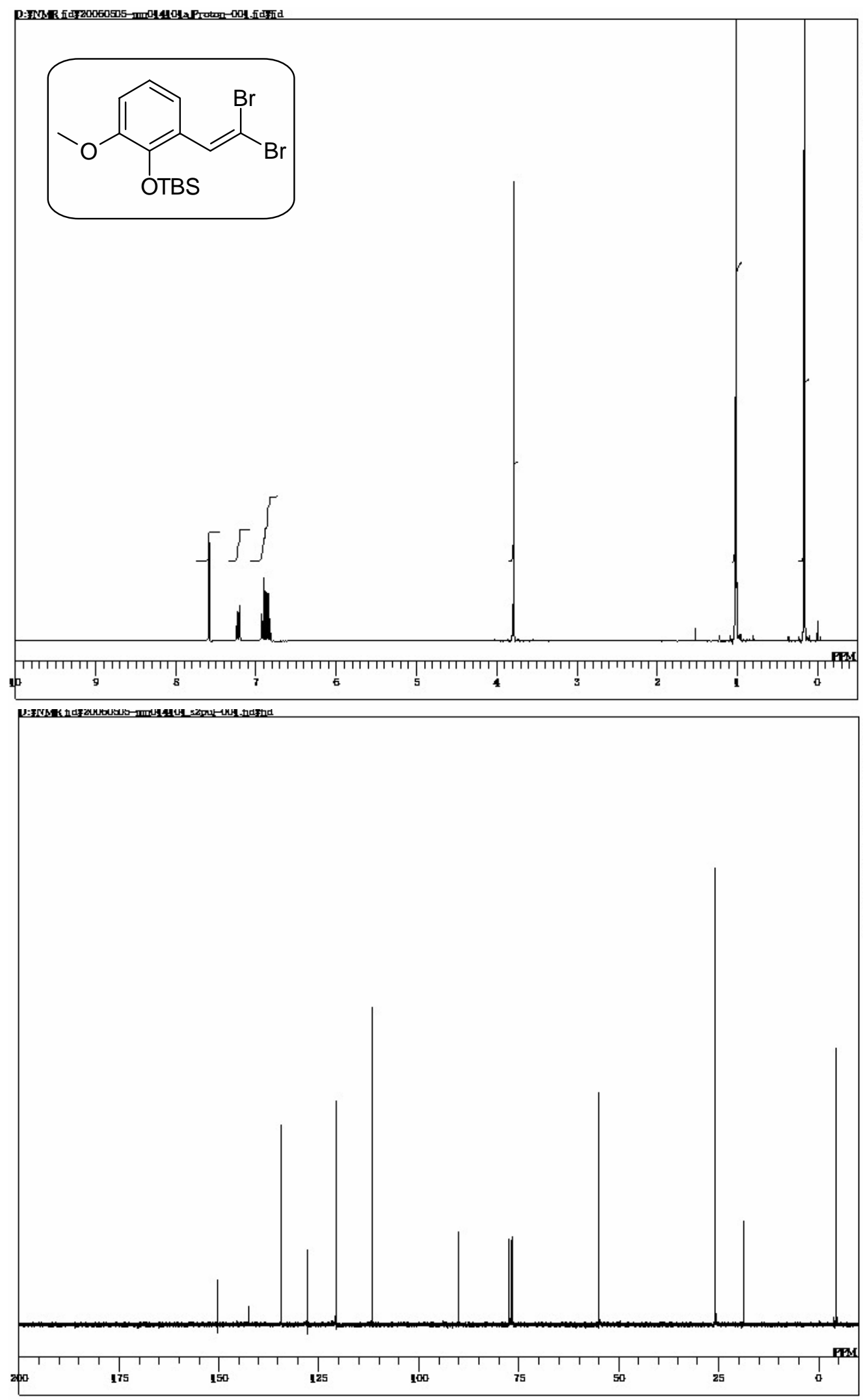

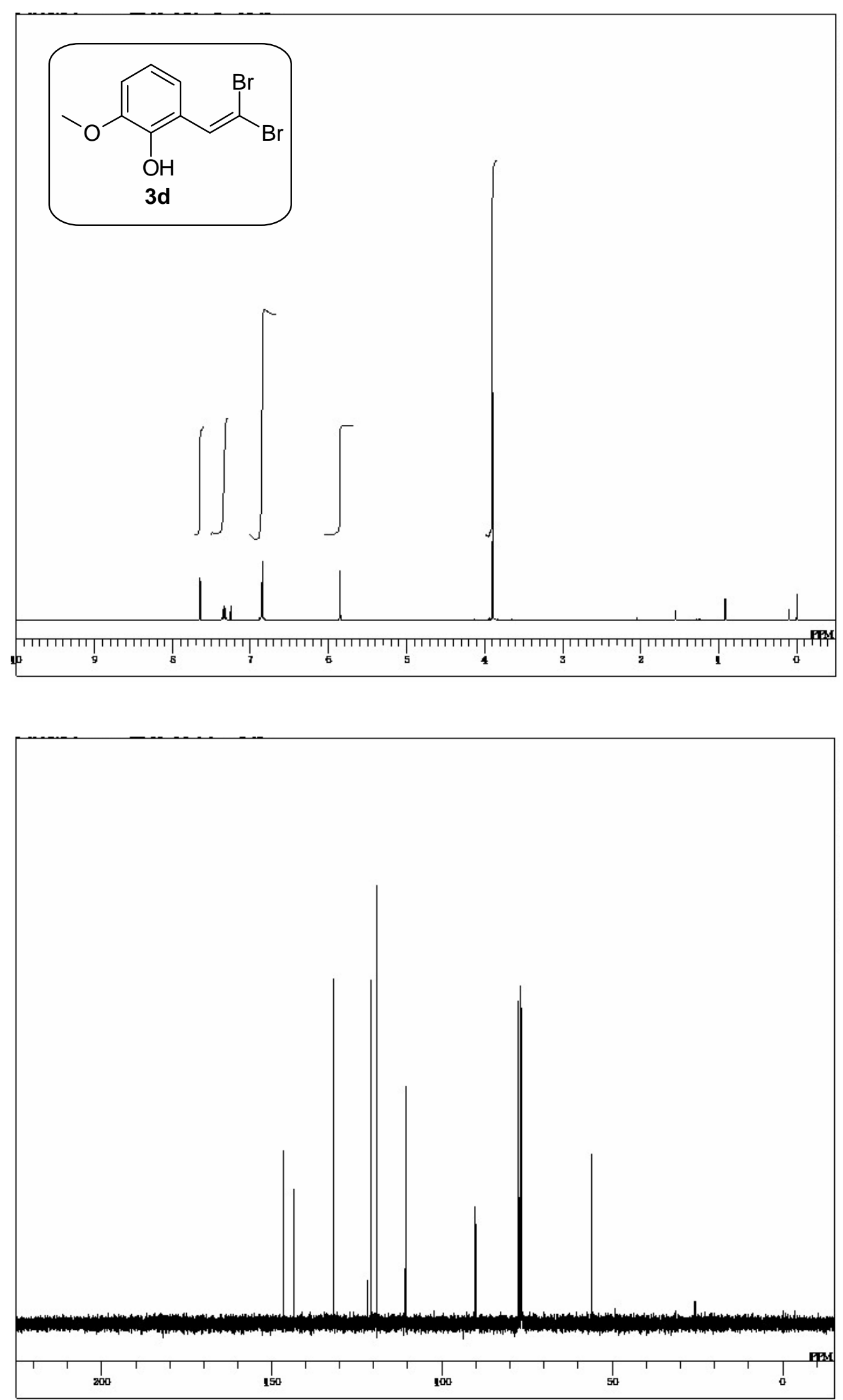

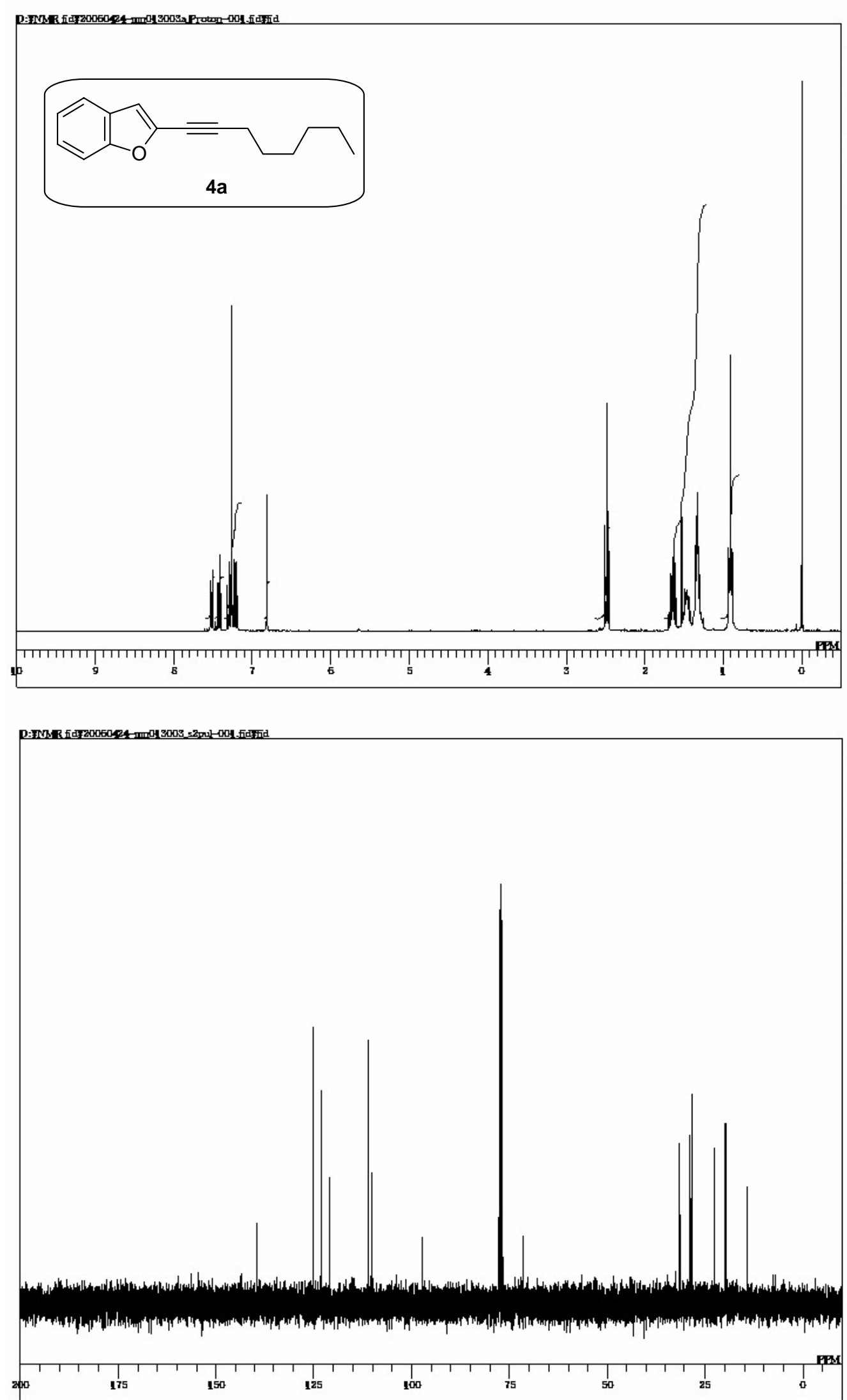

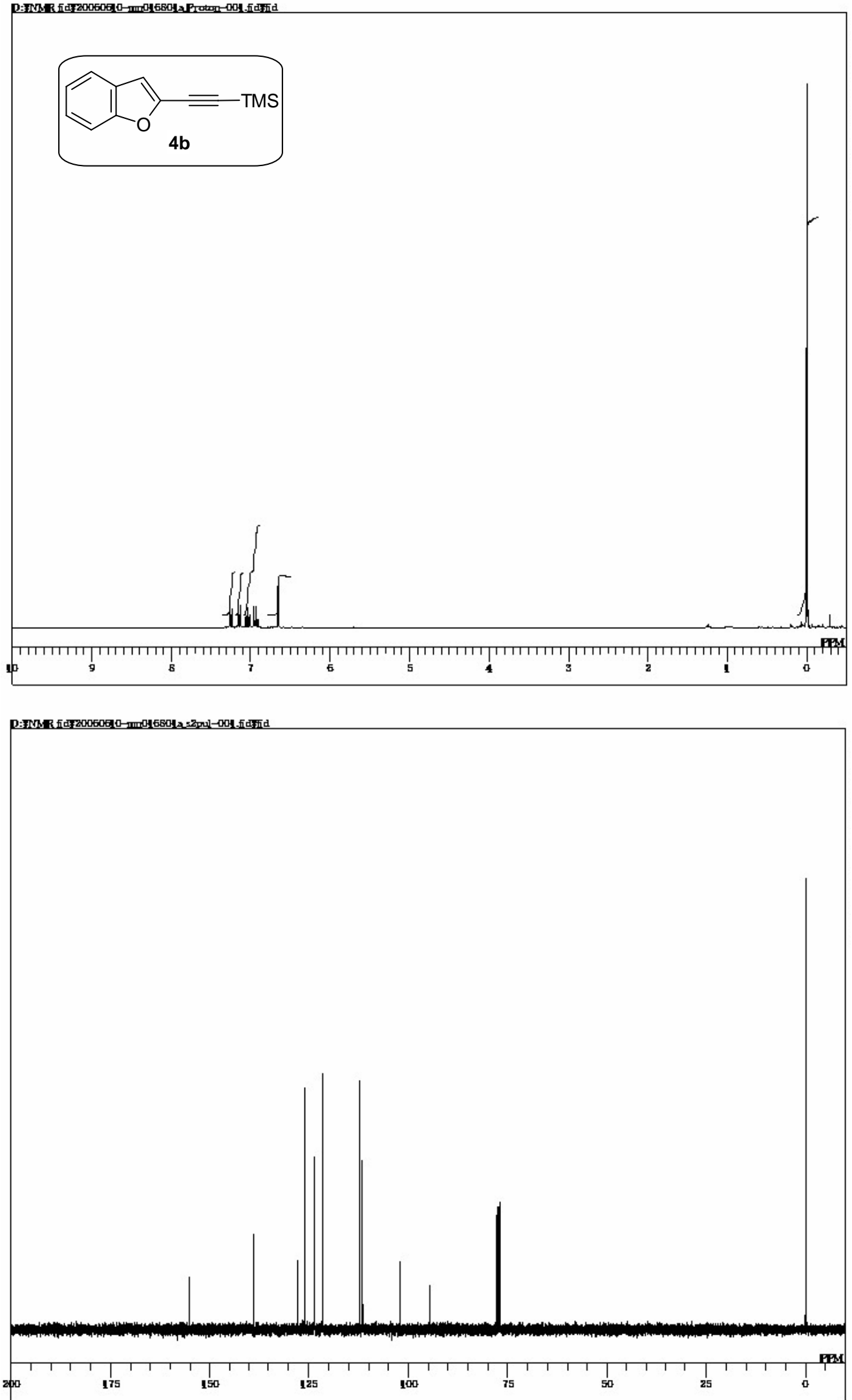

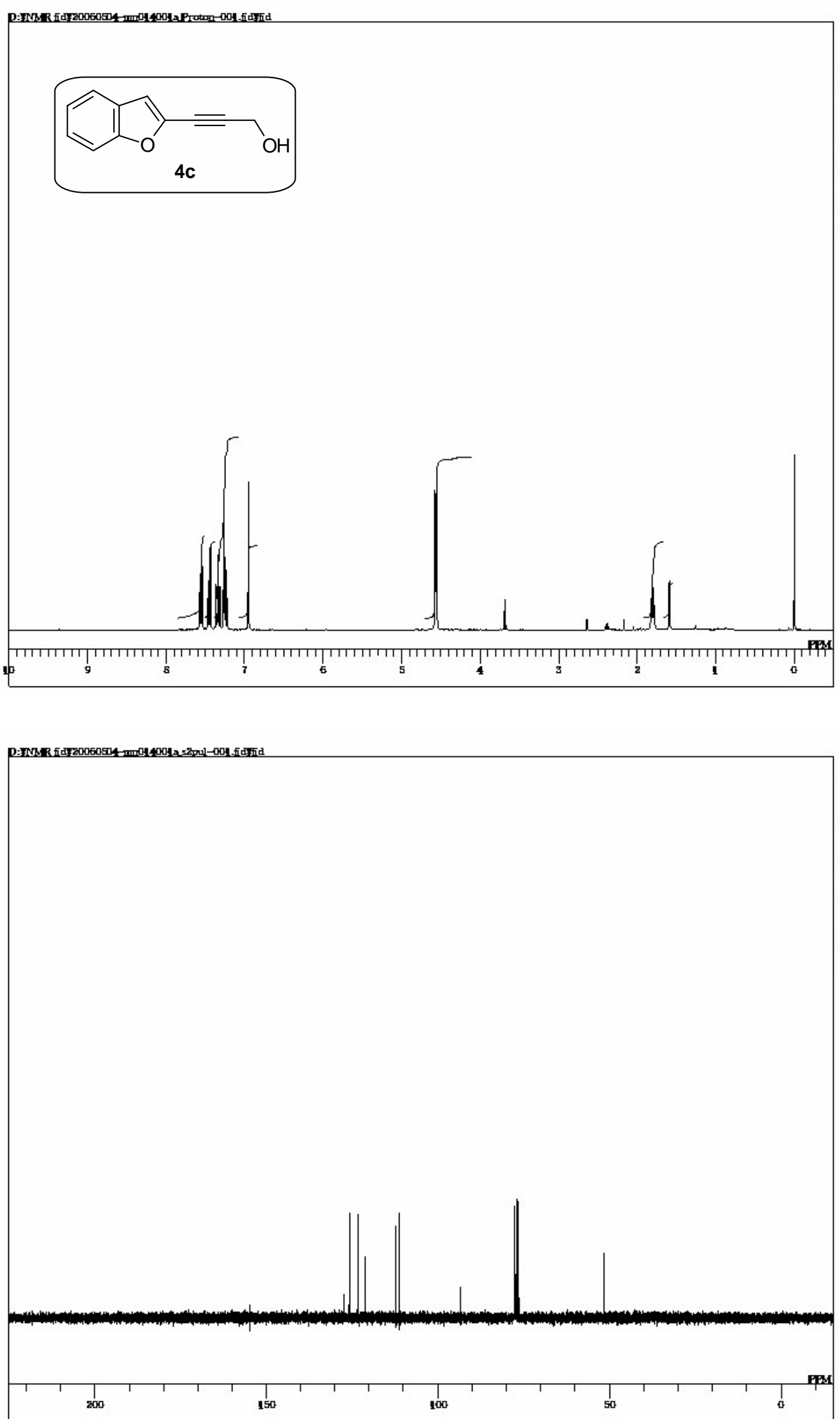


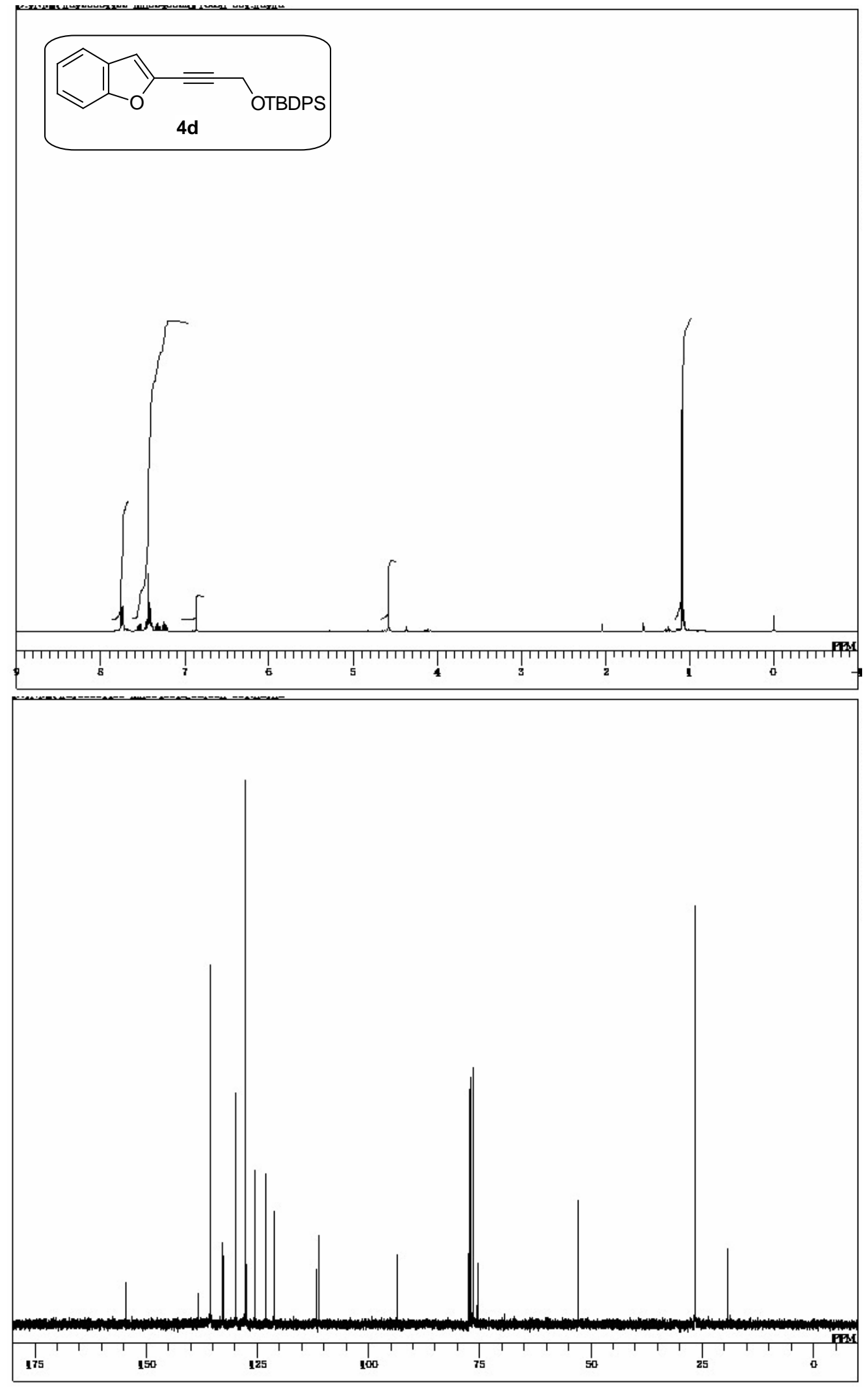

S55 

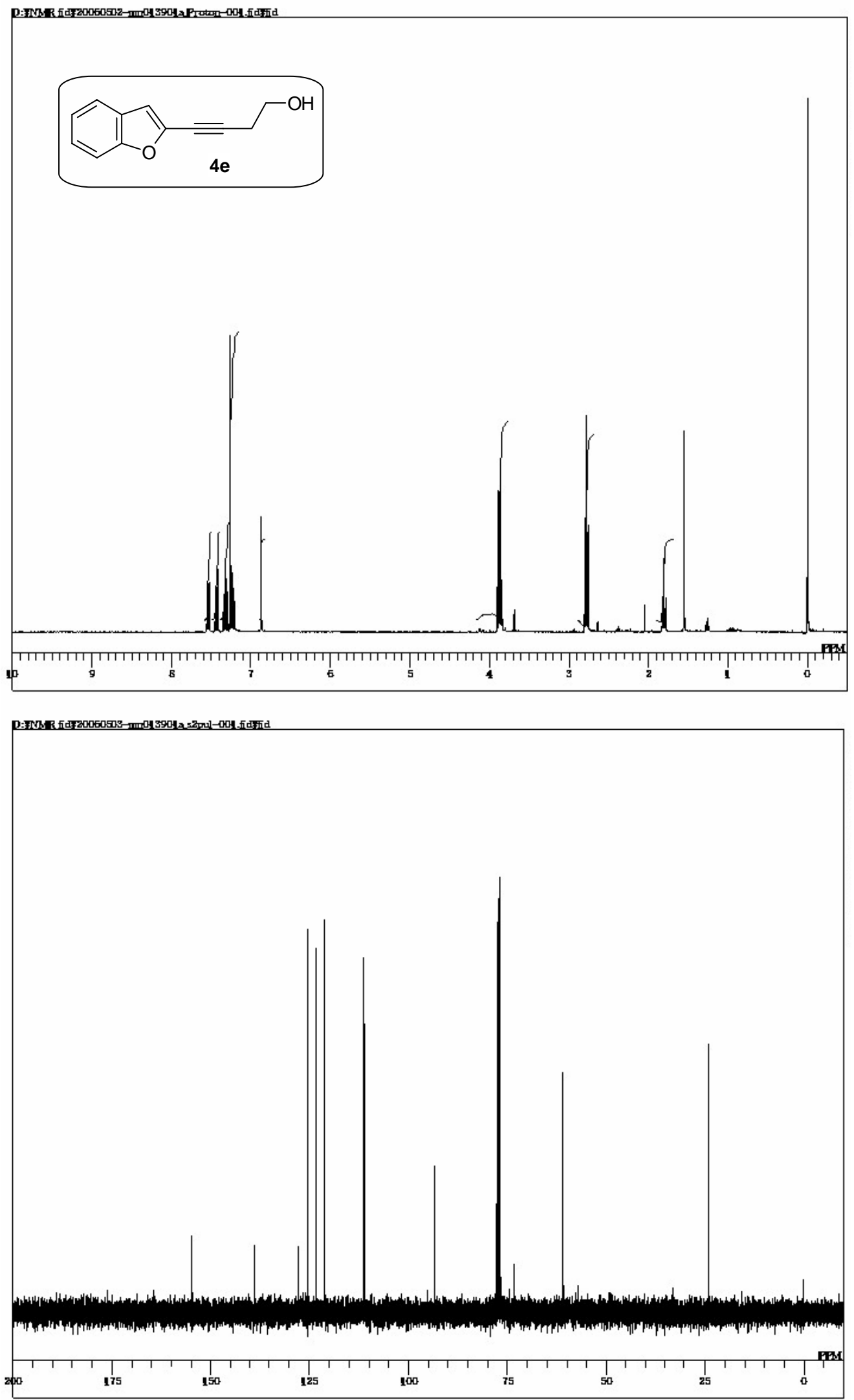

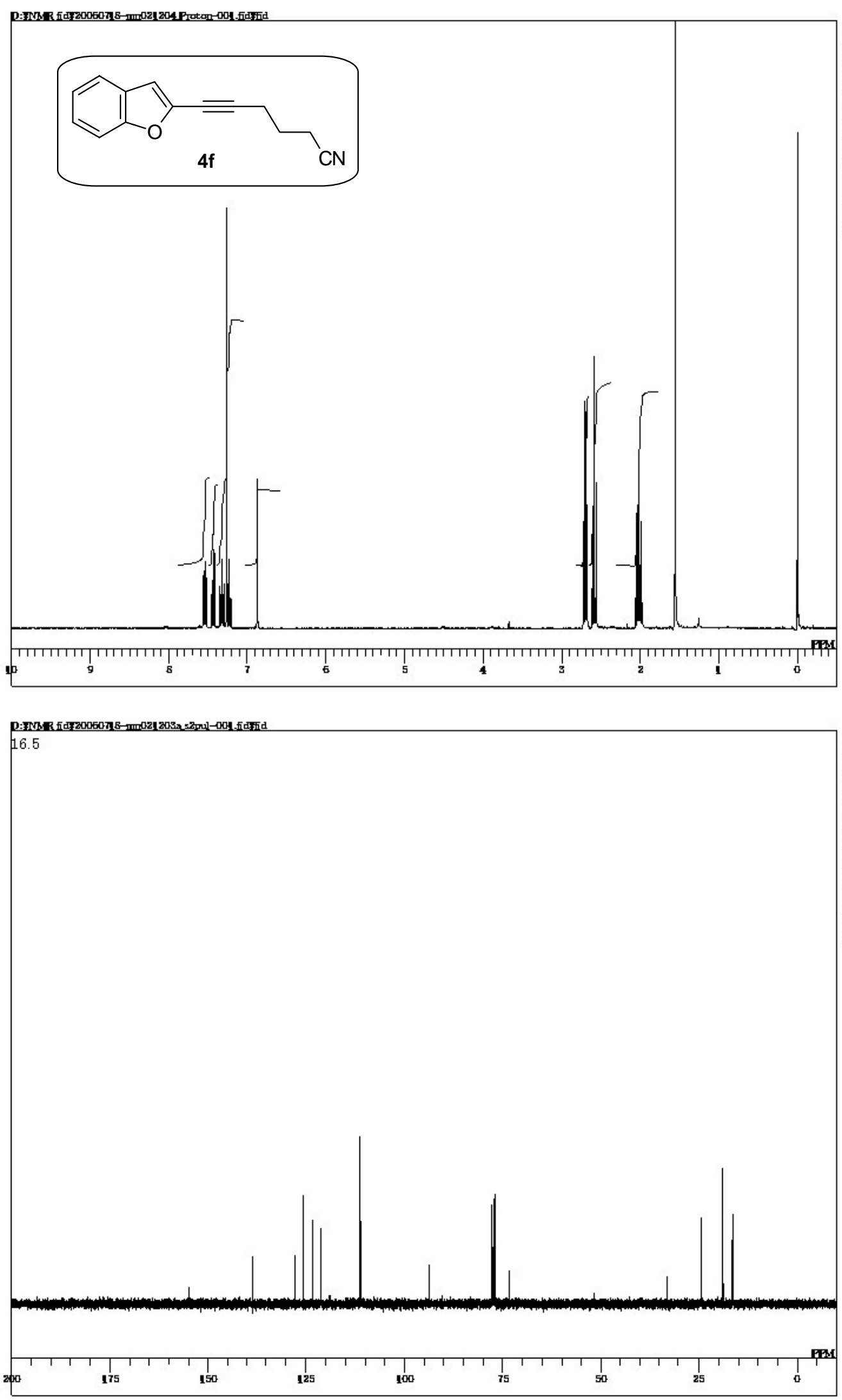

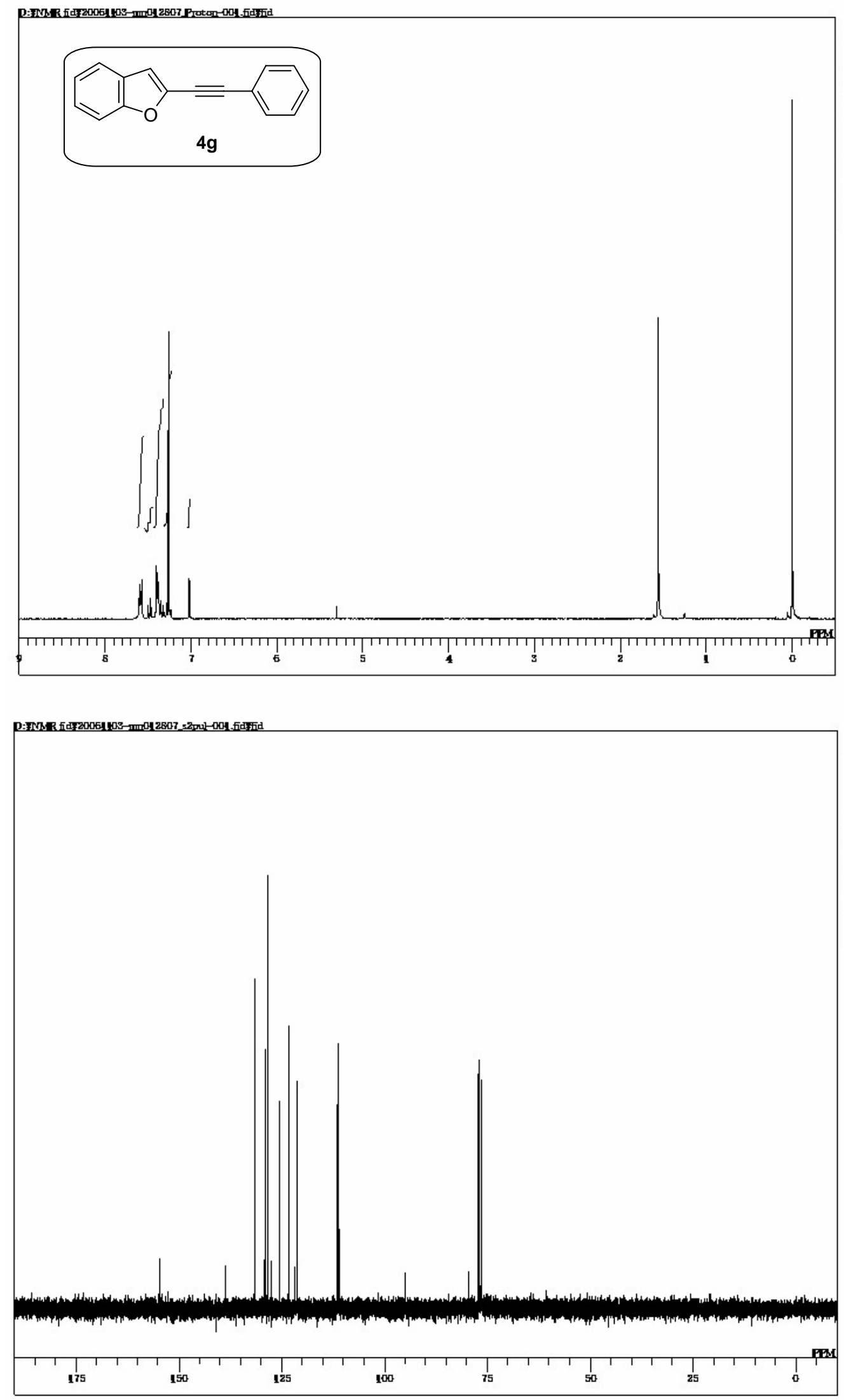

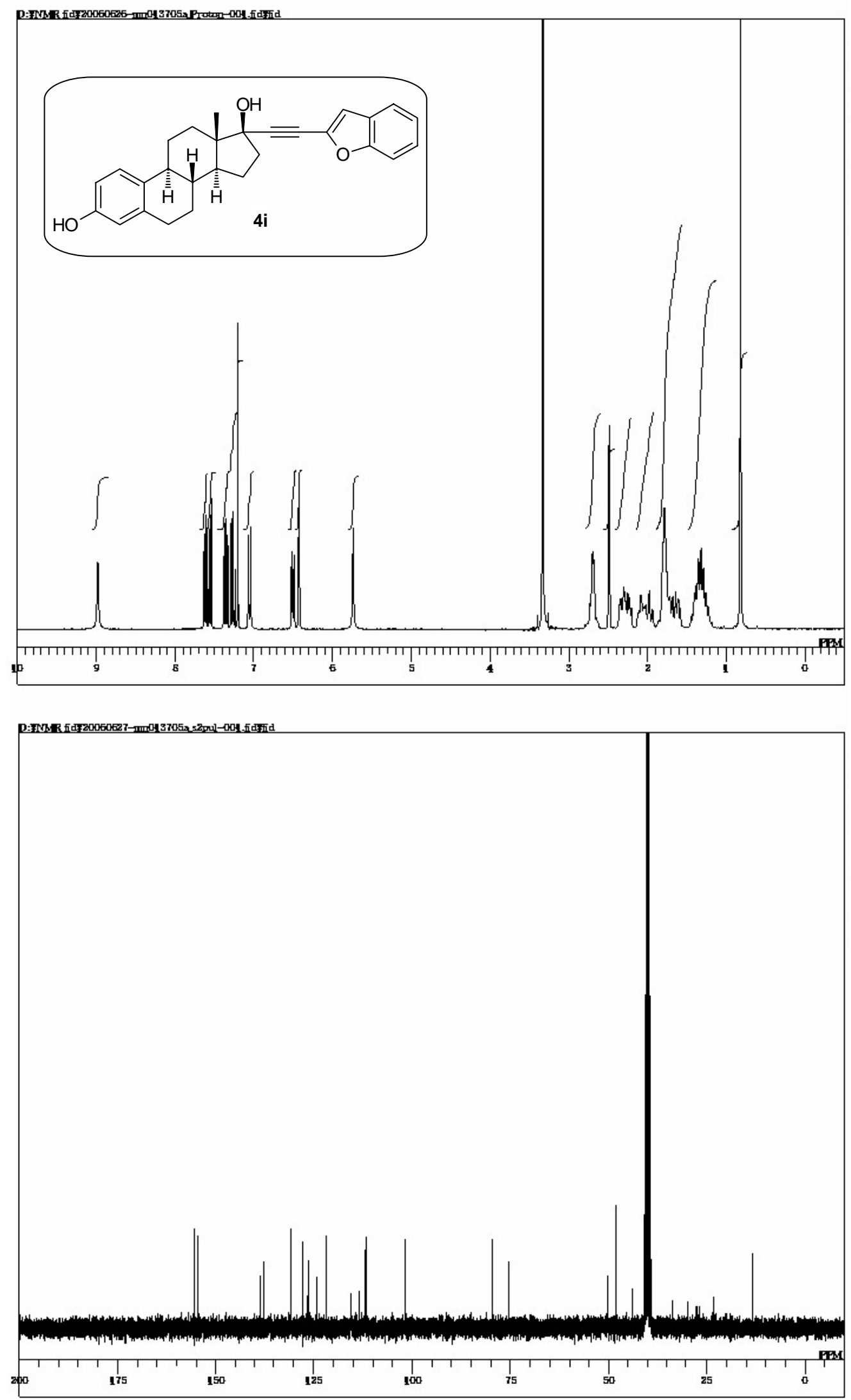

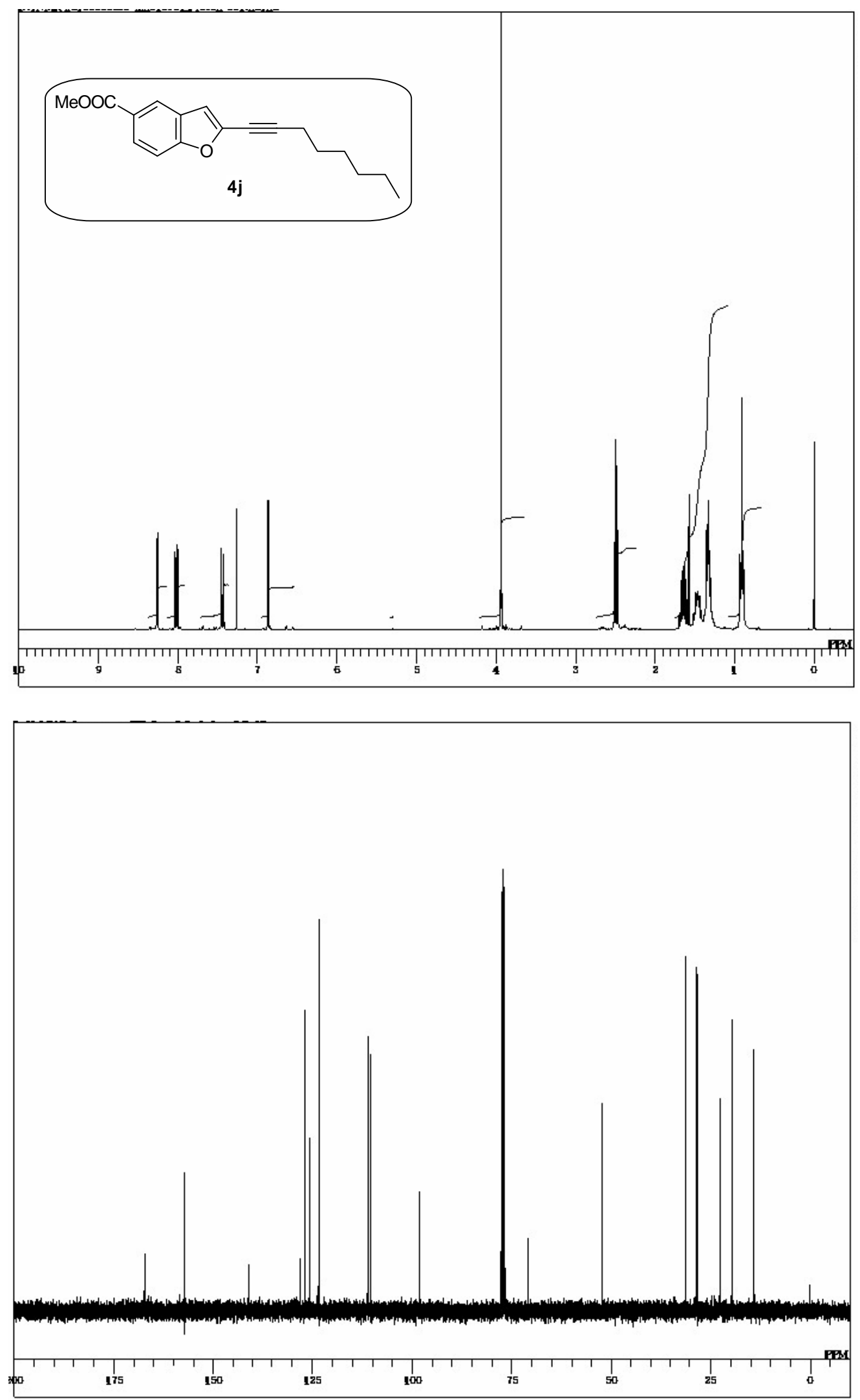

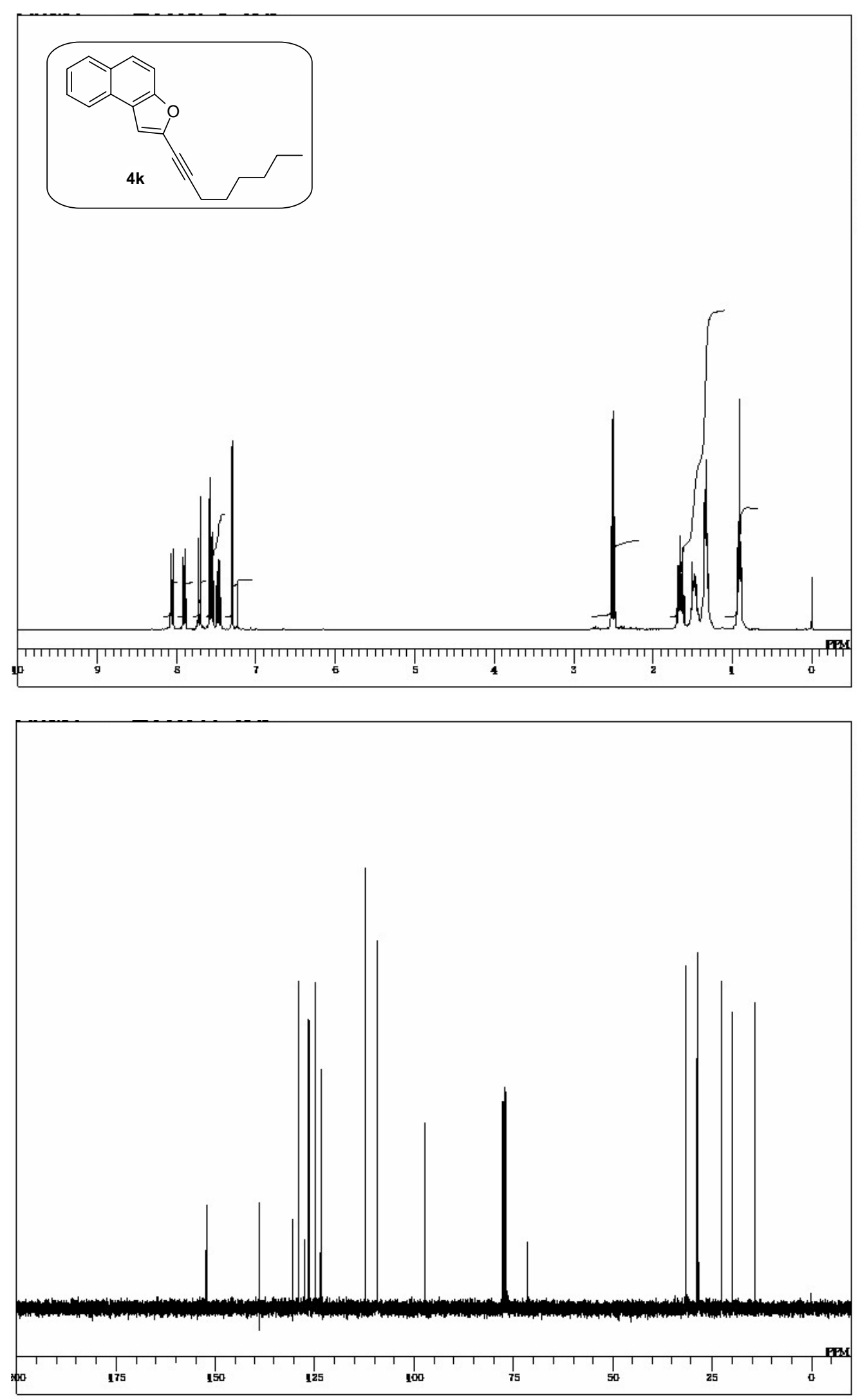

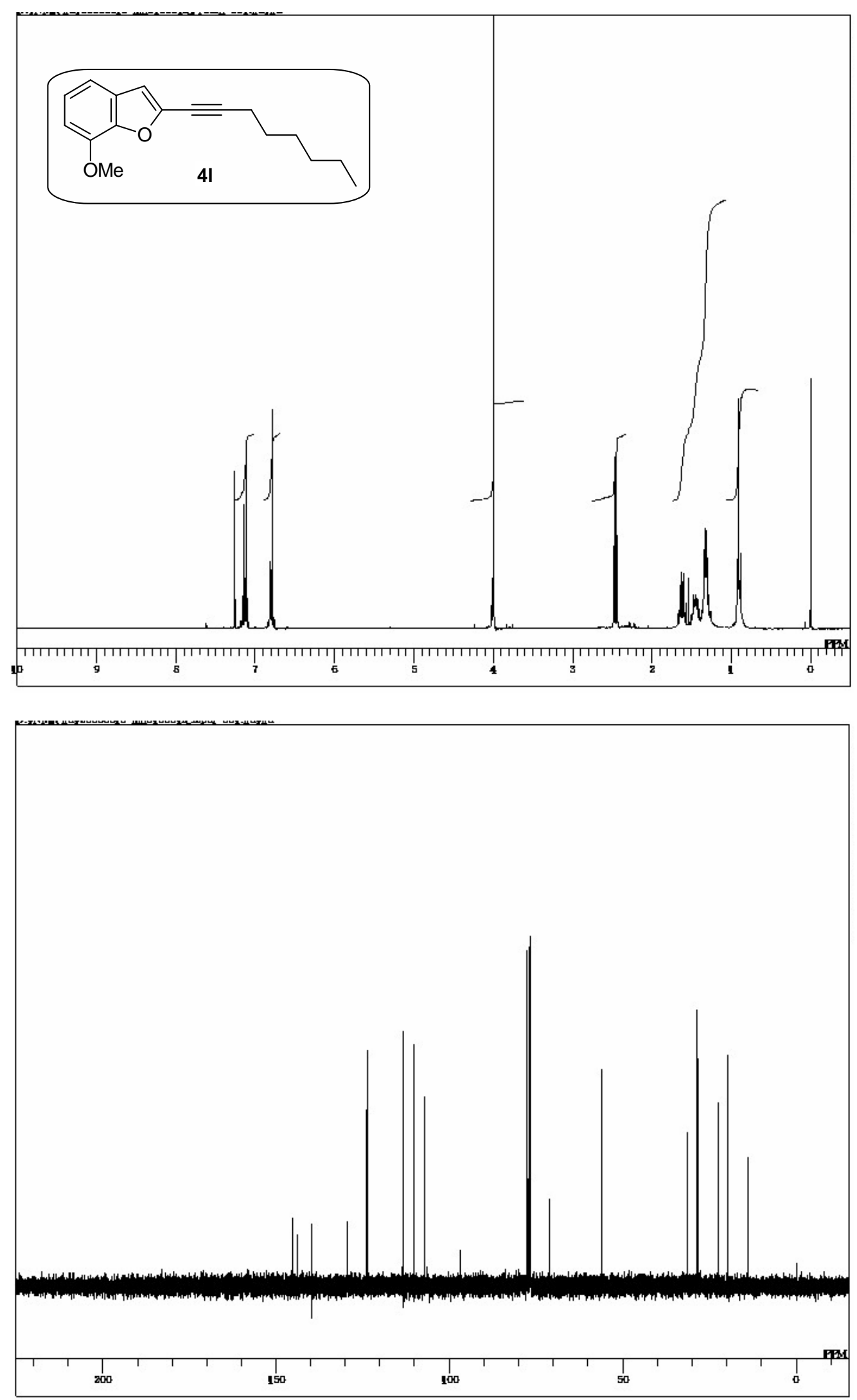

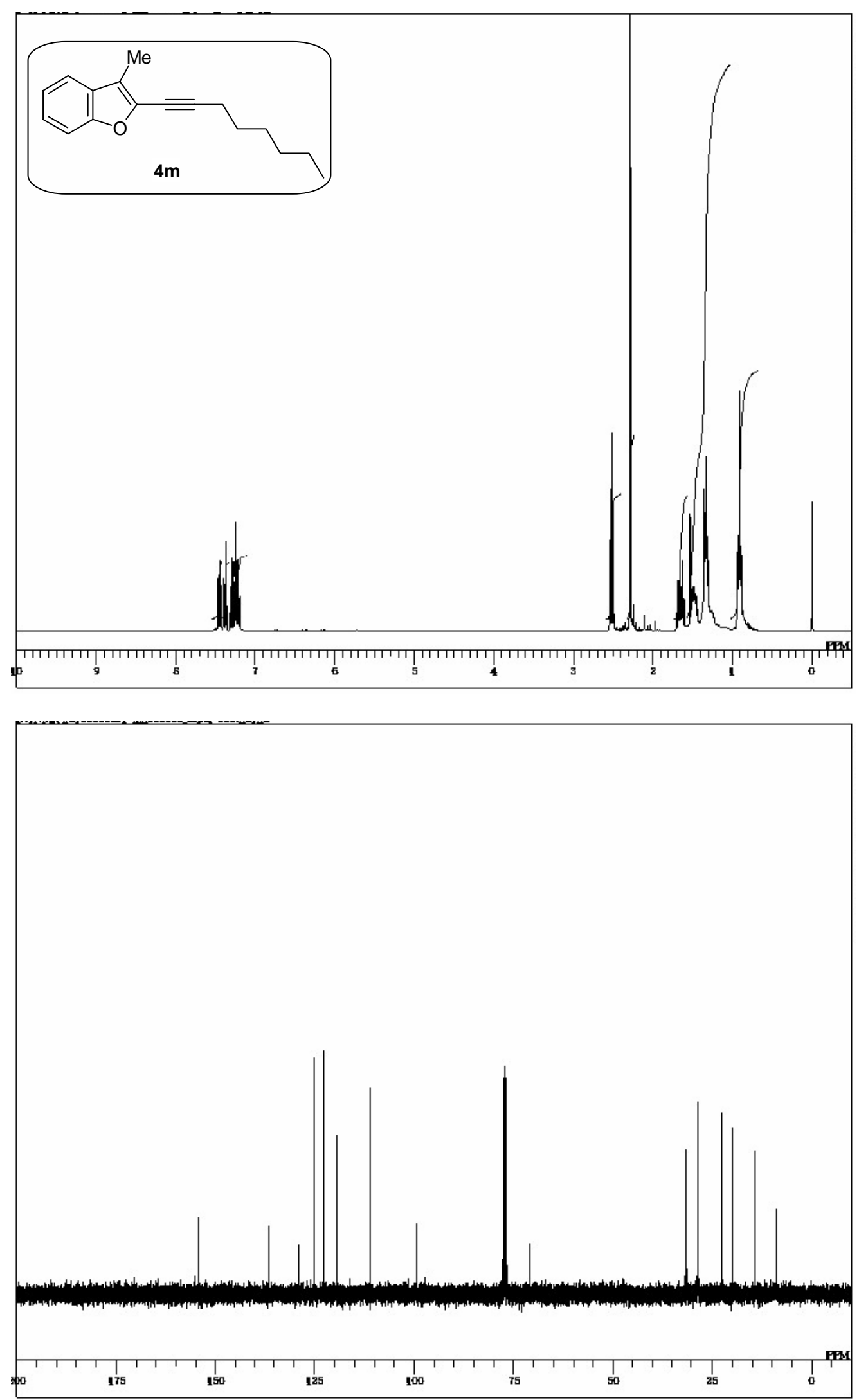